\title{
Ottoman Legal Attitudes towards Diversity
}

\author{
nui non haueuamo fatto paxe cum li soi tallasumani ne loro cum li \\ nostri preti
}

Ambassador GIOVANNI DARIO (1484)

In 1484, the Senate of Venice dispatched one of its citizens, Giovanni Dario, as ambassador to the Court of Sultan Bayezid II. An experienced diplomat, he had been appointed as ambassador to the sultan's predecessor Mehmed II five years before; on that occasion, Dario had to deal with the humiliating losses of a number of Venetian outposts, such as Scutari in Albania, and the rich colony of Negroponte in the Aegean, which had belonged for centuries to the Serenissima. After dealing with painful borderland issues during his first mission in Istanbul, Dario labored to prevent Ottoman involvement in Italian affairs pursuant to the war of Ferrara, which opposed the Papacy and his allies against Venice. During this episode of the Italian internecine wars, Pope Sixtus IV (1471-84) went so far as to invoke the Ottoman assistance against Venice, and proceeded to excommunicate the Venetians. The Turks, it has to be noted, declined to receive the Pope's ambassador to Istanbul on that occasion. In the context of these diplomatic intrigues, Dario attended numerous meetings with Ottoman dignitaries, the pashas, and as a result sent twentytwo dispatches reporting on his progress to the Doge and the Senate. In his missives, Dario addresses, among other subjects, a fair number of borderland issues, ranging from the enslavement of former Venetian subjects in regions recently lost to the Ottomans to the building of bridges across borderland watersides. It is in this context too that both the Venetian envoy and the pashas exchanged jokes about the excommunication imposed by Sixtus IV, and even about the news of the Pope's death. On several occasions, Dario confesses having found amusement in these irreverent exchanges with the pashas: "the other day the pashas said to me that the new pope had not yet absolved them of his excommunication, and I answered that this was not necessary, since the 
former pope had died, carrying the excommunication with himself, so they roared with laughter before they retired to meet the sultan, and in all sincerity I was unable to answer them otherwise." ${ }^{11}$ On another occasion, jokes about Venice's Italian enemies could hardly hide Ottoman concern for the fate of the Republic: "They questioned me about the Pope's recent death, of which I replied I had no news; they informed me of a letter sent to his excellency the sultan regarding this, confirming the news. Mehmet Pasha then started joking, we indulged in revelry-making and His Excellency rolled over with laughter." And indeed, we know that Venice's salvation in the war of the League of Cambrai was the object of public celebrations in the streets of Damascus in 1509. ${ }^{3}$

During one of these meetings, Dario advanced Venice's complaints regarding Christians living on the Ottoman-Venetian borders, who were being made prisoner during peacetime. In such cases, in order to ascertain the circumstances under which a given person had been delivered to Muslim hands as a slave, the Turks required the Venetians to advance two Turkish witnesses fitting Islamic standards for trustworthiness. According to these standards, witnesses needed to know the person whose slave status was being disputed, "should know the slave's mother and father by their names," and had to "be reputable Muslims, able to say their prayers." These "difficult and impossible conditions are so rigid," Dario informs the Doge, "that it actually means the Ottomans do not wish to return any prisoners, hence we were left in a worse condition in times of peace that we were during hostilities," since, he argued, at war "one takes precautions in order to defend oneself-but now, trusting the peace agreement, we are exposed and suffer attacks both from land and sea, since the former is packed with corsairs, damaging every day our towns and fleet." ${ }^{4}$

1 "L'altro giorno i pascià mi dissero che il nuovo papa non li aveva ancora assolti dalla scomunica ed io risposi che non era necessario perché il papa precedente era morto, ed aveva portato con se la scomunica; hanno riso a più non posso e ridendo entrarono dal Signore e io, a dire il vero, non potevo dar loro altra risposta.", Dario, Giovanni: 22 dispacci da Costantinopoli al doge Giovanni Mocenigo, edited by Giuseppe Calò, Venezia, Corbo e Fiore, 1992, 227 .

2 "me domando de la morte del papa, li respusi che mi non haueua alchuno auiso me disse che la Signoria soa haueua habudo lettera et che la iera certa. Mehemet Bassa comenzo a dir mille piaxeuelleze et fessemo un tanferuzo la dentro. et el Signor rideua quanto podeua," ibid., 119 .

3 Apellániz, Francisco: Pouvoir et finance en Méditerranée pré-moderne: le deuxième état mamelouk et le commerce des épices (1382-1517), Barcelona: CSIC, 2009, 245, n.25.

4 "me agreuai poi cum lui de li captiui nostri fati in tempo de paxe li quali voleuano che mostrasse do testimonij turchi che cognossesse per nome el pare et anche la mare et che fosse persone da ben et che sauesse dir le soe oracion et che questa condicion cusi stretta et impossibille me significaua che non haueria voia de restituirne alchuno captiuo et aquesto 
The Ottoman subaşı and officials, Dario went on, "go bird hunting, although their quarry are men, and our peasants' sons are apprehended as soon as they reach their farms." Dario mentions that these issues were brought before the Ottoman judicial authorities: "we have recourse to their voivodas and subaşıs for help, but it is those same officials who are responsible for these misdeeds, and who actually mock the reasons of our plaintiffs."

Just like the cases dealt with by the Venetian ambassador Dario, we often stumble upon descriptions of Ottoman officials hearing disputes and leading criminal investigations, and it is clear that traditional approaches to proof and procedure, such as those adopted by the qadis, were being followed in these cases. " "These extreme conditions we cannot stand, and," Dario said to the pashas, "since you are respectful of the law when acquiring slaves with your own money, even more discretion would be expected when dealing with us, your friends," ${ }^{\prime \prime}$ to which the pashas answered that "requiring Muslim witnesses of good standing is an article of faith." In his missive, Dario further noted that "such is the injunction of their gospels, that they could not counter their own laws. I replied by saying that we Venetians have not concluded a truce with your muezzins and neither have you with our priests and friars ... should we heed them, we would never be at peace, and never conduct any commerce, nor any dialogue. Instead, the rulers who seek to preserve their state leave the priests to sing their hymns in their houses of prayer, they sign peace treaties with whomever they wish and so they keep their promises."7 The pasha, surmising a Venetian connection to the unexpected death of Sixtus IV, then retorted that "you Christians can do this openly, since you have killed your pope and therefore are free of honoring any obligation, but we cannot do that."

modo eramo in pezor condicion in tempo de paxe, che non erimo in tempo de guerra", Dario, 22 dispacci, 91.

5 Baldwin, Islamic Law and Empire in Ottoman Cairo, 41. Hosainy, Hadi: "Ottoman legal practice and non-judicial actors in Seventeenth-century Istanbul", in: Law and Legality in the Ottoman Empire and Republic of Turkey, edited by Kent F. Schull, Bloomington: Indiana University Press, 2016, 23-33, 28.

6 "che queste erano estreme condicion le qual non podeuamo pui suportar et che le Signorie soe usauano descrecion cum li soi schiaui compradi cum li soi dinari tanto pui doueuano far cum li soi amici," Dario, 22 dispacci, 91-2.

7 "me respose chal fato de voler testimonii turchi de bona condicion era de iure diuino et cusi comandaua el so euanzelio et che elli non podeuano contrauegnire a le soe leze. Li respusi che nui non haueuamo fatto paxe cum li soi tallasumani ne loro cum li nostri preti et frati per che se vardassamo alor non stessamo mai in paxe ne hauessano insieme alchuno comerchio ne pur loquella ma li Signori che volleno la conseruation di soi stadi lassano li eclesiastici ne le soe giesie a cantar li soi officij et fano paxe cum chi che li piaxe et attendeno a quello che prometteno," ibid., 92. 
To judge by the hilarious tone of the conversation, the pashas were not lacking in a sense of humor, however what is more important for our argument is that the Turks were attempting to stress the moral obligations carried by governance, including respecting the biases against minority witnesses. Dario went on to claim, decidedly much less convincingly, that the Pope "might well have died, but the Church still lives and governs among us Christians." ${ }^{8}$ At this point, Dario introduced the problematic issue of captives from the OttomanVenetian borderlands: "his excellency laughed, but I cried, for I recall having seen in Constantinople, in chains, people known and close to me lost during the truce, begging for my help but, not being able to advance Turkish witnesses knowledgeable of the law, able to say their prayers and knowing their father and mother, I was unable to help them, so that they ended up being carried away and shipped to Anatolia with utmost cruelty, and as a result I clearly see it is impossible to keep the peace between us." ${ }^{\prime 9}$ As Dario was losing faith in the conversation, other officials present at the meeting began conversing, seemingly agreeing with Dario's argument - that is, that it was simply impossible to recover any of the Venetian captives by appealing to the qadi courts.

A delicate diplomatic mission similar to that encountered by Dario was entrusted to Andrea Gritti (1455-1538) in 1502, after the Ottoman-Venetian war. ${ }^{10}$ Lengthy negotiations led by Gritti and his secretary revolved around the Florentines' attempt to gain access to Ottoman lands through the Adriatic, and the proposal to create a foothold for Ottoman traders in Venetian-dominated Ravenna. ${ }^{11}$ Gritti faced the usual controversies that emerge during the drafting of treaties, such the handling of the estates of Muslims dead in Venice (and conversely, the seizure by the Islamic treasury of those belonging to Venetians) or the return of a number of slaves who were Muslims of Corfu and therefore Venetian subjects. The ambassador pushed the Ottomans to accept Venetian

"me respuse che vui podeti ben far questo ad abaldeza perche haueti morto el vostro Papa et seti asolti da ogni hobligo. ma nui non podemo far questo. Li respusi che sel Papa era morto e uiueua la giesia la qual era imortale et gouernaua nui altri cristiani." Ibid., 92.

"et che la Signoria soa rideua ma io pianzeua quando me arecordai huer vista in Constantinopoli in cadene persone ami notte et familiar persi in tempo de paxe li quali implorauano lo mio adiuto et per non hauer testimonij turchi et anche dottori che sapia la oracion che cognosesse el pare e la mare non li podeua souenire et veniuano strasinadi et tragettadi in la Natolia cum grande crudelta et che vedeua chiaramente che a questo partido non era possibile che fosse bona paxe entra de nui," ibid., 92.

10 Davis, James Cushman: Shipping and Spying in the Early Career of a Venetian Doge, 14961502, Florence, Leo S. Olschki, 1974 (Estr. da: Studi veneziani, vol. 16).

11 Discussions revolved around the Ottoman request to gain free access for Muslims to Ottoman lands through the Adriatic, a claim mentioned in successive treaties, De Groot, "The Historical Development of the Capitulatory Regime", 591. 
testimony for issues concerning the status and belongings of these Franks, and for which Muslim testimony was not available or undesired. In his own dispacci, Gritti received the same moral objections mentioned by his colleague Giovanni Dario: "Davut Pasha replied to this by saying that, according to their law, they could not accept witnesses other than Muslim, since otherwise they would carry that burden until Judgment Day; I feigned not to understand."12

The apparently isolated issues mentioned above in the diplomatic narratives of Dario or Gritti actually revolved around the same legal problem; that is, the biases of Islamic law concerning proof and unbelief. Since the rise of the Ottoman Empire as a military power, if not earlier, the biases had been brought to the forefront of governance and diplomacy. In this, the Ottomans marked a definitive break with a long-established Mediterranean tradition of weaving trade and diplomacy relations and of legally dealing with foreigners in the marketplace. To be sure, voices were most frequently raised in the bazar, particularly in the Arab provinces, where the legal change brought about by Ottoman domination most strikingly countered previous practice. In the 153os, a Venetian merchant wandered through the streets of Tripoli and Aleppo trying to ascertain certain sums owed by Muslims to a dead relative. He inquired after the former partners of the deceased, but hesitated to actually seek redress before the qādīs, since "no one is allowed to give testimony of their knowledge but Muslims." ${ }^{13}$ The Venetian consul in Egypt Lunardo Emo, discussing in July 1560 some businesses gone bad, mentioned that of a certain Pandolfo Contarini, whose ship had been seized. Emo deliberated about presenting Contarini's case to the Dìvān, as other Venetian residents had discouraged him from doing so: None of them, Emo argued, is able to testify, if only the Ottomans accepted the testimony of our merchants; [but] they are not used to this, since it is their custom and law, as Your Most Serene prince knows, to require Muslim witnesses. ${ }^{14}$ It is in any case hard to ignore that the biases had become

12 "Daut rispose etiam a questa ultima parte cum dir, che per la leze sua non se poteva aceptar altri testimoni che musulmani, che facendosse altramente ne haveriano gran carico fina al giorno del iuditio. Mostrai de non lo entender ...", Venice, Biblioteca Marciana (hereinafter BM), It. VII, 878/8652, Dispacci Gritti (1502), f. 22r.

13 "saper quella niuno satrova in aleppo apresente non so si debbo farla meter de qui e per non aver niuno possa testimoniar di saper salvo Musulmani," Venice, Biblioteca Correr (hereinafter BC), Manoscritti Provenienza Diversa c. 508c/6.

14 "Non sentono che'l se appresenti, non vi essendo manco alcuno di loro che potesse giustificar la carata della preditta nave ... chel magnifico meser pandolfo contarini non ne abbia a far niente, come vuol il commandamento, posto chel [ciphered text] si contentasse delle giustification de nostri, il che non usano, essendo suo costume et legge come sa Vostra Serenità di voler testimonii musulmani.", ASVe Senato, Dispacci Consoli, Egitto B1, 32, July 7th, 156o. 
commonplace in diplomatic conversations, so that awareness of their importance was expected of the Doge and the members of the Senate to whom the dispatches were addressed.

As I argued in Chapter Two, in Ottoman times people increasingly had recourse to hujjas and similar deeds registered in court, but this was most often done to protect their rights from potential threat, as has been shown by Rossistza Gradeva for the case of former slaves seeking to guarantee their freed status. ${ }^{15}$ However, in sharīa courts hearings continued to prioritize oral testimony, and almost no litigant adopted a line of defense based solely on documentary evidence. Closely related to this phenomenon, complaints also appeared about the unclear status of written documents. When he attempted to resolve some debt issues in the 1540 s, the Venetian Bailo stumbled over the Islamic mistrust for written artifacts as proof. He described what happened when he approached the Grand Vizier Rustem Pasha (d. 1561) with some Venetian letters, accompanied by an official Turkish translation: "I was required to prove that this money belonged to us, I showed the aforementioned letters, but he asked me whether I could advance further testimony other than those letters, and I exposed all my arguments to his excellency to no avail, so that the money has been seized. I wonder whether the pasha, under the pretext of a lack of oral witnesses, is plotting to appropriate the money for his treasury."16 Gianfrancesco Morosini, Bailo for thirty-five months in the 158os, complained that "as for their justice, the legal procedure used by the Turks to implement their governance is summary," and that criminal cases "are not heard in proper trials, but verdicts are reached through the hearing of oral witnesses." Incidentally, the Turks did not hesitate to torture criminal defendants, it was argued in several relazioni. "In civil cases, they do not take written documents into consideration," and it was noted that trials were started by the plaintiff before the qādīs or the kadıasker, who heard the parties and delivered a sentence on the basis of the witnesses' utterances. For family issues, instead, "they rely on the

15 Gradeva, Rossitsa, "On the Judicial Functions of Kadi Courts: Glimpses from Sofia in the Seventeenth Century," Wiener Zeitschrift zur Geschichte der Neuzeit, 5/2 (2005), 15-43. Gradeva has advanced similar considerations regarding the motivations for minorities or women seeking to have documents notarized, Gradeva, "Orthodox Christians in the Kadi Courts: The Practice of the Sofia Sheriat Court, Seventeenth Century".

16 "questi danari, dovesse probar, che fossero de nostri et io mostrandoli le lettere predicte diceva, che non poteva darli maggior testimonio che dette lettere, nientedimeno non mi ha valso alcuna ragion che habbia detto in questo proposito a sua magnificentia di modo che li danari stano cosi in deposito. Forse chel detto bassà con questa difficultà mossa da probar con testimonii, ha pensato di appropriarli alla casenda.", ASVe, Archivi Propri Constantinopoli, 1, fasc. IV, f. 116, (154-47). 
Koran." For the 16th-century author of the Viaje de Turquía "the justice of the Turks treats everyone as equals: Christians, Jews and Turks". He describes qadis as having "a crufifix on their desks to take the oaths of Christians and a Bible for the Jews". Second only to the sultan, The kadiasker is the chief justice, who proceeds by hearing witnesses, while criminal matters are left in the hands of governors and officials such as the subaşı. The latter are familiar with physical punishments: they kill murderers, hang thieves and impale traitors. Ottoman governance is particularly ruthless with debtors hiding their wealth. Qadis, instead, apply punishments to minor offenses by means of the stick. Great attention is paid to false witnesses: they are paraded on the back of donkeys, their faces smeared with ink, they are finally marked with an iron and invalidated to give testimony, a point of particular importance to which I will return. ${ }^{17}$ This thumbnail sketch of Ottoman justice therefore stresses a civil procedure that was marked by the two biases under consideration in this book, by the importance of testimonial witnessing in a cross-confessional setting, by the qadis' inability to independently start trials, ${ }^{18}$ the role of officials, the widespread adoption of ta'zīr or discretionary punishment in criminal cases, as well as a family law characterized by a religious imprint. For Bailo Giovanni Moro, "judges seek promptness, neglecting long speeches by attorneys," reached quick decisions and paid little heed to the reading of documents, "quite in contrast with the procedure in other countries." 19 The requirement to produce Muslim witnesses heavily impinged upon cross-confessional relations, but it also went hand-inhand with the summary nature of Islamic justice and its mistrust of writing and documentation.

When dealing with Ottoman judges and judicial authorities, not only Venetian merchants and diplomats, but also craftsmen, seamen and even slaves encountered unexpected legal difficulties. Indeed, as the opening quotations of this chapter underline, the principal obstacle these foreigners came up against was the Ottoman 'witness system,' which privileged Islamic notions of proof and evidence. ${ }^{20}$ In a 16th-century context, the difficulties posed by the biases were not confined to the domain of jurists and litigants, but pervaded political

17 De Villalón, Cristóbal: Viaje de Turquía, edited by Antonio G. Solalinde. 2 vols., Colección Austral; 246. Madrid: Espasa-Calpe, 1965, 213.

18 Tyan, Histoire de l'organisation judiciaire en pays d'Islam, II, 23.

19 "Attendono i giudici alla brevità e, tralasciando i lunghi sermoni d'avvocati, risolvono prestamente le cause con poca lettura di scritture, molto diversamente dall'uso degli altri paesi, quando non siano comprobate col detto di testimoni," Relazioni degli ambasciatori veneti al Senato, Serie III, Volume III, edited by E. Albèri. Vol. IX, Florence: Società editrice fiorentina, 1855,376 .

I borrow this expression from: Ozil, Orthodox Christians in the late Ottoman Empire. 
and diplomatic encounters. Even though Gritti-significantly-pretended not to have understood the implications of the biases, he and his colleagues were of course well aware of these legal inconveniences, and they expected the same knowledge of their metropolitan correspondents. In this final chapter, I look at the legal attitudes adopted by the Ottomans, which made relations at the market and in court look so different than they had previously in the medieval Mediterranean. Whatever their origins, these attitudes and ideas about sovereignty and legal order have been connected with those adopted by other central Asian, post-Mongol states. By 1517 the Ottoman Empire was an old polity, and indeed these attitudes formed part of a broader tendency to regulate the hanafĩ school, reaching back to the mid-fifteenth century. ${ }^{21}$ Giovanni Dario explicitly formulated the problem some thirty-five years before the Ottoman conquest of the Arab provinces. In this chapter, I focus on the fulcrum of crossconfessional diplomatic and legal exchange, the Dìvān-ı Hümāyūn in Istanbul, although on occasion I will turn to Egypt and to the Syrian provinces, where Ottoman choices had a greater impact on the local judiciary and in the markets. The concluding section of this chapter, which looks at a case of bankruptcy, makes it clear that, shortly after the conquest of the Arab provinces, Frankish litigants were disoriented by the stubborn insistence of authorities on having transactions registered at the courthouse, and by their adherence to the biases against minority witnessing.

Whatever importance the Ottoman witness system exhibited in the field of norms, and despite recurring complaints by Venetians and other users of the justice system, it was not, as the Bailos would have it, a mere arbitrary device, but rather a tool for expressing a specific version of the legal order. To be sure, the reliance on local witnesses led to abuses that required the attention of the Ottoman authorities, such as the proliferation of false witnesses selling their services to the highest bidder. However, it cannot be said that this strict adherence to the biases actually hindered trade, or overly favored local Muslims; rather, the biases played out in the complex social reality of the Empire, where they were manipulated, and sometimes contested, by local minorities, by the Franks themselves and, on occasion, benefitted foreign Muslims. By the same token, implementation of such discriminatory measures in the daily life of the markets entailed the adoption of a series of exceptions and amendments to the general rule that, on occasion, came at odds with the very same hanafi legal order the Ottomans sought to embrace. Indeed, the biases took center stage

21 Burak, The second formation of Islamic law, 207-23, Burak, Guy: The Abü Haniffah of his Time: Islamic Law, Jurisprudential Authority and Empire in the Ottoman Domains (16th-17th Centuries), PhD thesis, New York University, 2012, 25-6. 
in all kinds of exchanges and relations across confessional boundaries, as the Bailos experienced, but also generated many controversies and often provoked contradictory and chaotic legal situations. Venetian negotiators were of course open to accommodation with the pashas and actually kept an open diplomatic channel in the Dīvān, far beyond the occasional exchange of embassies. Yet in light of the passages examined at the beginning of this chapter, one can hardly present the pashas as pragmatic diplomats ready to put aside Islamic notions and ideas in order to reach a profitable agreement. Rather, the Venetian ambassadors took great care to inform the Doge and the Senate of the difficulties posed by sharīa when dealing with issues of proof and testimony. This strict adherence to skeptic sharía principles only further complicated the already chaotic sphere of legal definitions and relations with unbelievers, which as we have seen manifested itself in the divergences between amān theory and practice, and in the difficulties arising from its actual application. The adoption of the biases as one of the founding principles of Ottoman governance certainly drew a line of demarcation between Muslims and non-Muslims in cross-confessional disputes, but it ended up generating more problems than it actually solved. Indeed, this very central role given to the biases made them so cumbersome as to generate a series of contradictory discourses and practices, epitomized in the 'Aleppo ferman' issued in 1557.

I open this chapter by taking a juristic approach to the question, and specifically, the two vectors governing, according to hanafi doctrine, the ways in which unbelievers could participate in the legal system. Yet it is my contention that a study of the Ottoman framework of governance amidst diversity needs to take account of actual practice, including some of these contradictory aspects and discourses. In this chapter, my aim is to historicize these specific attitudes and notions about proof, justice and belonging, as described by Frankish litigants. I will be dealing with some of these anomalies, not as uninteresting exceptions, but rather as peculiarities that encapsulate the very essence of the Ottoman distinctive attitude to justice. I will be addressing the objections raised by dhimmì minorities- the 'carazari clause' - and exceptional measures such as those sponsored for Aleppo, where foreign Muslims were actually prejudiced by the specifically Ottoman approach to proof and evidence. In connection with this, I look into the proliferation of false witnessing, a phenomenon that began to develop in the sixteenth century, in a similar manner to the forgery of documents evoked in Chapter One. The most significant among all these alterations to the general normative framework of justice, however, was the privilege granted to Franks according to which Muslim witnesses were not accepted in mixed lawsuits. In all of these contentious cases, the strife between juristic 
discourse, government-sponsored practice, and actors' reactions from below pushed the system into a state of tension.

I conclude this chapter with the story of a Venetian merchant who fell bankrupt in Syria in the late 1520s, and by describing how his default was dealt with by Ottoman judges and judicial authorities. ${ }^{22} \mathrm{~A}$ trader in diamonds, rubies, pearls and luxury armors, Marco Priuli found his customers among the Syrian upper class, including judges and officials, as well as their wives and daughters. Muslims, but also Jews and Christians were all equally affected by his default; as his creditors, his debtors, and as his associates. The lawsuits that ensued after Priuli's death in the Ottoman prisons are representative of many of the obstacles commonly met by people dealing with cross-confessional affairs in the Early Modern Mediterranean. If there was little doubt about Priuli's responsibility for his own bankruptcy, the judges concerned themselves more with determining the liabilities of Priuli's partners, as well as the claims of his debtors. The several courts involved faced many pressures when attempting to decide whose credits should be paid, by whom, and what witnesses should be heard first. The legal discussion revolved certainly around facts, but surprisingly plaintiffs, judges and attorneys spent a great deal of energy and time dealing with issues of proof and procedure, and with their application in the context of religious diversity.

Marco Priuli's Venetian heirs and associates proved to be unfamiliar with the legal practices sponsored by the Ottomans, and with the court's requirements for proof and evidence. This seems particularly surprising for members of a veteran trading nation that proudly claimed five centuries of presence in the area. Indeed, they seem to have clashed over particular issues whose implementation under the Ottomans had started to deviate from previous legal practice. As an early Ottoman example of commercial litigation, the Priuli lawsuit echoes the discomfort generated by the Ottoman stance vis-à-vis Frankish merchants. I have referred to the fact that, for more than a century, there had apparently been no complaints about the witness system. Yet once Ottoman judges began sitting in justice in the former Mamluk provinces, these complaints began surfacing in the documentation. The abiding principle that an unbeliever's word should not be used to harm the interests of a Muslim was invoked first by a Syrian qadi entrusted with the affair, and later again by Muslim plaintiffs at the Imperial Council—the Dīvān-ı Hümāyūn—where the Priuli lawsuit was heard in appeal. Apart from reflecting well-known Ottoman legal attitudes, the Priuli lawsuit also offers instances of accommodation, as well as 
some puzzling anomalies, such as the repeated claim that a Frank could not bring forward a Muslim witnesses.

We know that the Ottomans disapproved of the way in which legal principles had been implemented under the Mamluks. It was not so much the principles themselves that they took issue with, as their formalistic approach to them. The medieval 'udūl, recognized by local judges and registered in court, had become in Mamluk times numerous in tribunals and administrative offices. ${ }^{23}$ Ibn Iyās describes the measures taken against Cairo's 'udūl, targeted by Ottoman legal reforms, soon after the conquest, in 1517 and in 1520, and Ibn al-Hanbali puts it in very bold terms, stating that in Aleppo, "under Ottoman rule, the notarial stalls were closed," reporting personal accounts of notaries who were forced to seek a different profession "after the Circassians." ${ }^{24}$ Under the Ottomans, as became evident in the Priuli lawsuit, traditional recourse to the notary-witness began to be replaced by the practice of having transactions notarized at the qaidi court. ${ }^{25}$ The lawsuit sheds light on the problematic adaptations that had to be resorted to in response to this new situation, provides us with an example of a case being transferred from a qādī court to the Imperial Dīvān, and offers a glimpse into both the Ottoman version of the witness system and its loopholes.

By doing away with some of the practices prevalent under the Mamluks, such as Siyāsa trials for foreigners, the Ottomans set a line of demarcation with the conquest of Mamluk Syria and Egypt in 1517. This, again, is viewed in a problematic light by researchers dealing with the late Ottoman court registers. Indeed, the strong biases against unbelievers relaxed in the late Ottoman period, thus creating conditions more conducive to mixed justice in the contemporary era. The seminal research conducted by authors such as Najwa alQattan has shown that the judges of nineteenth-century Damascus or Aleppo considered it justifiable, if needed, to rely on the word of a Christian against that of a Muslim. ${ }^{26}$ The Priuli lawsuit epitomizes an early modern scenario where Franks had to deal with qadis and sharīa as sponsored by a rising Ottoman power, thus enhancing the historical contrast with medieval practice. In this early modern scenario, the legalistic approach to cross-confessional relations was taken very seriously, sometimes definitely at the Ottomans' own advantage but also when the ruthlessness of such rules made agents fronting

23 Meshal, "Antagonistic Sharīas", p. 183-212.

24 Ibn al-Hanbalī, Durr al-habab fi tarikh a'yan Halab, 921-2, 98o.

25 Fitzgerald, Ottoman methods of conquest, 229.

26 Masters, Christians and Jews in the Ottoman Arab world, 31-33; Al-Qattan, "Dhimmis in the Muslim Court: Legal Autonomy and Religious Discrimination". 
the new legal regime scratch their heads. By the same token, the conditions under the Priuli lawsuit stand in marked contrast with the late-Ottoman context, where Capitulations, privileges and berats favored, allegedly, the emergence of a pathway of European legal institutions alternative to sharīa.

\subsubsection{The Early Ottoman Adjudication System}

The Ottomans gave the hanafì qādī a much more central role in the judicial stage, at the expense of other potential judges, such as the officials who used to pass verdicts in Siyāsa courts under the Mamluks. As was the case for the Priuli bankruptcy, in the Ottoman provinces all mixed affairs were first adjudicated by the local qādì. Moreover, both Muslims and unbelievers were expected to register their debts, contracts and depositions at the qādì court, who would stamp his seal on the resulting deed, and in the presence of honorable Muslims. ${ }^{27}$ This constituted a break with the Mamluk past as regards mixed transactions, when the Franks had their contracts notarized by Latin notaries, Muslim notary-witnesses, by courtiers or even concluded oral agreements. ${ }^{28}$ Having become compulsory under Ottoman rule, this certifying function of the Ottoman judge rendered obsolete previous forms of notarization, not only for the Islamic notary-witness, but also for the Latin notaries who, during the late Middle Ages, were usually sent to Islamic countries to draw up Latin deeds. ${ }^{29}$ Under the new Ottoman system, as long as an act had been certified before a judge, one's religion didn't really matter. The problem, however, was that many transactions, agreements, debts and oral contracts were concluded outside of this ideal framework, and when businesses turned bad the parties could not always prove that a given agreement had been reached, or that a particular debt had been contracted. By the time Priuli fell bankrupt, proving and notarizing had become synonymous to a hitherto unknown extent.

The Ottoman legal discourse put emphasis on the Islamic communal vision of governance and justice. Although, in practice, foreigners of all sorts were in great abundance in places such as Istanbul, in principle unbelievers sojourned by virtue of a communal agreement underwritten with the ruler, and they did

27 Van den Boogert, The Capitulations and the Ottoman Legal System, 44-5; Wittmann, Richard: Before Qadi and Grand Vizier: Intra-communal Dispute Resolution and Legal Transactions Among Christians and Jews in the Plural Society of Seventeenth Century Istanbul, Ph.D. Dissertation: Harvard University, 2008, 72-3.

28 On the widespread recourse and compulsory character of notarization, Faroqhi, "Before 16oo: Ottoman attitudes towards merchants from Latin Christendom", 77 and n. 31.

29 Canbakal, Society and politics in an Ottoman town: Ayntab in the 17th century, 129-30, argues that "whether or not the Ottoman 'udul continued to act as notaries, could not be established with any certainty." 
so on a temporary basis. ${ }^{30}$ According to this ideal principle, the Islamic ruler was disposed to hear his guests' complaints against oppressive officials and qādīs, ${ }^{31}$ and a foreigner dissatisfied with a qādī sentence could therefore seek redress from the sultan at the Dīvān-ı Hümāyūn. As I have been arguing, this jurisdiction corresponded with medieval mazâlim although, under the Ottomans, it was not referred to by this name. Consequently, the Dīvān passed verdicts in appeal for many mixed disputes, and at least during the sixteenth century these trials exhibited a strong communal bias. ${ }^{32}$ Contrary to ordinary Muslim petitioners, European Christians were represented by the head of their community. In practice, ambassadors such as the Venetian Bailo brought their subjects' claims to the Imperial Council, where Ottoman pashas would hear the case and refer it to the ruler. In practice, the Ottomans discouraged recourse to the Divaann, limiting it to claims exceeding a certain amount. While before 1517, any Frank could sue a Muslim before the hạjib and other officials in any Mamluk town, after this date it was only the Ottoman sultan in Istanbul who dealt with mixed issues, and treated only with community representatives. Bringing grievances before the sultan in Cairo—-the mazālim-although the option always existed, was discouraged under the Mamluks. Under the Ottomans, instead, a trial at the Dìvān was in fact the only possible option in appeal after a local qadi had heard the case.

Historians of Ottoman treaties underline the fact that the Ottomans refused collective responsibility for individual debts, and treated the Bailo simply as a diplomatic representative, rather than as the head of a confessional group. ${ }^{33}$ Yet as we shall see, this was subject to some limitations. The Bailo Antonio Rizzo admitted in his dispatches to the Doge that, unlike in cases judged by a local qâdī, the Bailo was not totally exempt of communal responsibility at the Dìvān. Historians have a tendency to ignore differences with later periods, presenting the European ambassadors with their later incarnation in mind, as professional diplomats devoted to the granting of privileges and capitulations,

$30 \quad$ Krstić, "Contesting Subjecthood and Sovereignty in Ottoman Galata", 1613-1617.

31 Guy Gerber, Haim:State, Society, and Law in Islam:Ottoman Law in Comparative Perspective, Albany: State University of New York Press, 1994, 58-79, Ursinus, Michael: Grievance Administration (şikayet) in an Ottoman Province: the Kaymakam of Rumelia's 'Record book of complaints' of 1781-1783, New York: Routledge, 2004.

32 On the Dīvān's role as a court of appeal, Ginio, Eyal: "Coping with the State's Agents 'from Below': Petitions, Legal Appeal and the Sultan's Justice in Ottoman Legal Practice", in Popular Protest and Political Participation in the Ottoman Empire-Studies in Honor of Suraiya Faroqhi, edited by Eleni Gara, M. Erdem Kabadayı and Christoph K. Neumann, İstanbul Bilgi University Press, 2011, 41-57, 45.

Faroqhi, "Before 16oo: Ottoman attitudes towards merchants from Latin Christendom", 77. 
who intervened in the Dīvān court as part of their professional duties, or simply as personal favors. ${ }^{34}$ The role played by the experienced Venetian Bailo Pietro Zen suggests instead that Bailos were considered more as the grantees of the amān and as heads of a protected community, and therefore expected to be responsible for their subjects in court. ${ }^{35}$

Although the Ottoman certification system signified a giant's step towards the generalization of written artifacts as legal evidence, it arose within a context still largely dominated by orality. During a conversation between a Bailo and a Pasha quoted by the former in 1557 , the ottoman official admitted that "in the Dìvān, where they do not make notes, my word is trusted more than a qadi's sijill". ${ }^{36}$ Bailo Barbarigo, in his report to the Senate, expressed his irritation with the Gran Vizier Rustem Pasha, who undermined the role of the Re'īs ül-Küttāb and the Nişancı and monopolized the Dìvān's decision-making process for himself. ${ }^{37}$ Although sixteenth-century Ottoman judges preserved more legal documents than their medieval predecessors, the Venetians remained puzzled by the fact that no court records were kept by the Dìvān. The Priuli affair was heard by both Ottoman qadis and pashas, before a third trial was filed before the Venetian commercial courts. The extant Venetian documents describe the litigants' recourse to multiple forums back in the Ottoman Empire, and comprise vivid descriptions of the hearings held both by the qādīs and pashas, with a particular interest for issues of proof and procedure.

\subsection{The Legal Grounds of the Ottoman Witness System}

Half a century ago, as part of the proceedings published by the erudite academy Société Jean Bodin, the Italian historian Mario Grignaschi devoted a study to the treatment of witnessing and religious diversity by Ottoman jurists. To be sure, Grignaschi did not seek to compare his findings with actual courtroom practice; however, his results did nonetheless shed light on the link between practice and jurisprudence. Grignaschi searched Istanbul's libraries for

34 Dumas, Juliette "Müste'min Dealing with the Ottoman Justice: Role and Strategy of the Ambassador", Oriente Moderno 93 (2013), 477-494.

35 As Işiksel rightly argues, consuls and Bailos were considered both as heads of a community and as part of the Ottoman administration, and differently from the ambassadors leading occasional diplomatic missions, Işiksel, Güneş: "Hierarchy and Friendship: Ottoman Practices of Diplomatic Culture", 15-6.

36 "in divano, dove che non si fa nota ... la mia parola è creduta più che sigilleto," ASVe, Senato, Dispacci degli ambasciatori e residenti, Costantinopoli, B. 1A, f. 432.

Relazioni degli ambasciatori veneti al Senato, Serie III, Volume III, 155-6. 
manuscripts containing fatwās collected by Ottoman jurists, but also by Arabs and scholars based in the Mughal Empire. His work offered a new angle on the transformations experienced by the regime of proof around 1500. Grignaschi argued that special attention was devoted to infidels when dealing with issues of witnessing and testimony. Arab-i.e., medieval- jurisprudence was instead more focused on issues of conversion, while a real interest for witnessing amidst diversity only arrived with the Ottomans. Ottoman scholars, at the time, did not yet have much of a taste for novelty, and Grignaschi established very strong ties between Ottoman views on the problem and available precedent, in particular with ḥanafī medieval thinkers such al-Sarakhsī. Incidentally, al-Sarakhsī (d.11o6), flagged as the reference for later Ottoman views on diversity, was originally from Transoxiana-a central Asian commercial crossroads-and therefore belonged to the regional legal school responsible for a more dynamic approach to exchange with non-Muslims, to the use of documentary evidence, and which coined expressions such as "the hanafi exception."38

Half a century after the publication of Grignaschi's seminal work, my focus moves away from a jurists' approach to law, to concentrate more on the practical handling of these burdensome sharīa principles in forums such as the Dīvān. For this purpose, I make extensive recourse to the colorful narratives provided by Venetian representatives (dispacci, relazioni), particularly since documentary production at the Divañn was limited to the drafting of petitions and the resulting decrees, leaving most of the decision-making process undocumented. An examination of cross-confessional issues of proof and evidence can give us a better understanding of how Middle Eastern societies made use of their jurists, and shed light on the relationship between scholars, rulers and the people involved in the consumption of justice.

\subsubsection{Vector One: the 'Hanafi Exception'}

One phenomenon observed by Grignaschi is particularly worth examining, as it emerged as an important vector in legally relations between the Ottomans and Frankish consuls, merchants, and others: since an early date in Islamic law, hanafì scholars such as al-Sarakhsī endorsed the view that all dhimmīs constituted a single people under the aegis of their Muslim social superiors. The idea of a single dhimmī nation was based on the assumption that the ties binding different religions together should be considered stronger than their

38 Johansen, "Formes de langage", 365-9, Johansen, Baber: "Entre révélation et tyrannie: le droit des non-Musulmans d'après les juristes musulmans", in: Contingency in a Sacred Law, 219-37. Leiden: Brill, 1999, 138. 
communal differences, by virtue of their shared, subordinated socio-political status, and their common enmity for Muslims. By claiming that unbelievers all belonged to the same people, and that dhimmis could bear witness against each other even if they did not share the same beliefs, al-Sarakhsī set himself in opposition to most shāfi'ì, mālikī and ḥanbalī scholars. ${ }^{39}$ Mālik, Ibn Ḥanbal, Ibn Abī Laylā, al-Awzāī and to some extent al-Shāfî̀ expressed reserves to the fundamental unity in infidelity, distinguishing between scriptuaries and not, stressing the plurality of beliefs and setting limits to inheritances across confessional boundaries. ${ }^{40}$ Such open attitudes were probably not the norm in Islamic history, and the hanafis backed their views with the precedent established by the Prophet, who acted as judge in Medina, as well on the cosmopolitan garrison-cities of early Islam, where judges were often compelled to sit in justice over non-Muslims. Although many jurists simply refused unbelievers any right to testify, Abū Yūsuf (d. 729) and Ibn Abī Laylā (d. circa 702) accepted dhimmī witnessing, although only for claims within their own communities. ${ }^{41}$ Most hanafîs argued that Muslims were neither present at the dhimmis' deathbed, nor did they attend their weddings, and therefore their own witnesses should be permitted, as otherwise this could lead to a "loss of rights" for the dhimmīs. ${ }^{42}$ Jurists argued that women's testimony, for this same reason, was accepted for events that occurred inside the hammām, or in other places were upright male Muslims were absent. This argument was usually extended to encompass the acceptance of other 'diverse' witnesses, such as a child brought to trial for having torn another child's clothes. ${ }^{43}$ This legal reconfiguration, by virtue of which Christians and Jews could testify either for or against each other, but not against Muslims, is therefore known as the hanafi exception. The hanafi exception was therefore a first vector towards forming legal attitudes about Franks and other foreigners, not only in court, but also in more political scenarios, such as at the Imperial and provincial Dīvān.

39 Yusuf Ragib, Actes de vente d'esclaves et d'animaux d'Egypte médiévale, vol. 2, Le Caire: Institut Français d'Archéologie Orientale, 2006, 105.

40 Friedmann, "Classification of unbelievers in Sunni Muslim Law and Tradition", 57-8.

41 Anver M. Emon, Religious Pluralism, 136-41; Ragib, Actes de vente d'esclaves et d'animaux, $105^{-15}$.

42 Sarakhsī, Muḥammad Ibn Aḥmad: Kitāb al-mabsūț, edited by Muḥammad Rādī, 30 vols., Cairo, Mațba'at al-Sa'adah, 1324-31H, 19o6-13, XVI, 135. Ibn Nujaym, Zayn al-Dīn Ibn Ibrāhīm (1520-63): al-Ashbāh wa-al-nazāàir 'alá madhhab Abì Hanīfah al-Nu'mān, Damascus: Dar al-Fikr, 2005, III, 283.

Sarakhsī, Kitāb al-mabsūt, XVI, 136. 


\subsubsection{Vector Two: Mustä’mins Cannot Testify}

Muslim jurists took great care to differentiate between the people of the book - and more precisely local Christians and Jews-and apostates, heathens and other categories of people from outside the Dār al-Islām. In contrast with local minorities, the latter did not belong to the abode of Islam and therefore did not share the same motivations as the dhimmis. The crucial term underpinning this argument is walāya, evoking notions of friendship and sanctity, but most often those of obedience and authority. Contrary to local dhimmīs, mistrust for the mustämins as bearers of truth was justified by the latter's alleged lack of waläya vis-à-vis the Muslims. Frankish merchants protected by ahdnames constituted an intermediate and, in early modern Istanbul, numerous category (20.000 people, rumors had it, in the 1610s). ${ }^{44}$ According to the hanafīs, mustā'mins were outsiders and therefore not supposed to be interested in safeguarding the common good if summoned to court as witnesses. ${ }^{45}$ Actual relations between Franks and local minorities in Istanbul confirm the views of medieval hanafí jurists on the inferior legal status of Franks vis-à-vis local minorities. In the light of the legal claims they raised, Ottoman local minorites had good reason to mistrust foreign Christians. Indeed, for more than two centuries hanafî jurists advanced the claim that cross-confessional witnessing might be harmful, since Frankish witnesses might be tempted to target rival, local minorities in the course of litigation. Since local communities were subject to the payment of the poll tax, or carazo in Italian-Turkish jargon, I will refer to this legal claim as the 'carazari clause,' often discussed in diplomatic exchanges. Conversely, and as we shall see, the Ottoman official position was to claim that all unbelievers present in Ottoman territory constituted $a$ single people, and were all included in the Muslim enterprise of governance and therefore equal as subjects of the sharīa-based legal system. In other words, both dhimmīs and mustāmmins were expected to testify for and against each other. By so doing, the Ottomans were not just embracing the hanafi exception, but twisting the arm of standard doctrine so as to include foreigners in it. In this matter, the Ottomans departed from the letter of the jurists, hence tracing a thin red line between legal theory and actual governance.

To be sure, it was not the original intention of the hanafí jurists to include harbīs (disbelievers hailing from outside the lands of Islam) in their argumentation. As we have seen, in principle the hanafiss mistrusted the mustāmmins, and the hanafĩ exception did not offer legal coverage for them. In plain words,

44 Krstić, "Contesting Subjecthood and Sovereignty in Ottoman Galata", 438.

45 Emon, Religious Pluralism, 31. 
mustā’mins-Frankish merchants in our case, were not allowed by hanafĩ jurists to testify against local Christians and Jews. High medieval hanafis such as al-Sarakhsī, ${ }^{46}$ al-Marghīnānī and later ones such as Badr al-Dīn al-'Aynī (13611451) explicitly denied mustāmmins the right to act as witnesses, since they were not residents in the Muslim polity and could not be trusted to act in others' best interests. ${ }^{47}$ Dhimmīs were placed in a higher position within the Islamic polity, and belonged to the abode of Islam ('our household' ar. daruna), which was not the case for foreign Christians, or harbis, hailing from the abode of war (harb), where social relations were based on violence ( $\dot{g} a s ̧ b)$. Although the founding fathers of jurisprudence such as al-Shāfíi and Mālik denied dhimmīs any right to act as witnesses, al-'Aynī argued that the Prophet accepted their testimony when judging their intra-communal affairs. Most importantly, and unlike local minorities, foreign unbelievers were only allowed to testify in cases were both parties in the case belonged to the same nation (ar. dār).$^{48}$ Hanafi texts often quote a passage by al-Sarakhsī explaining that outsiders such as "a Byzantine and a Turk," lack common belonging (walāya) and unlike dhimmīs, who are under "our $d \bar{a} r$," would naturally tend to target each other. ${ }^{49}$ These attitudes were crystalized in a fatwā in which the hanafĩ Ottoman jurist Ebu'ssu'ud (circa 1490-1574) questioned what would happen if Amer, a hypothetical Venetian Bailo (in spite of his Turkish name), was sued by a dhimmī creditor. After initially denying his debts, the Bailo confesses that the debt actually did exist, but claims it has already been honored. He produces two Venetian witnesses who give evidence that counter the claims advanced by the dhimmì. Should these testimonies then be accepted? Ebu's-Su'ud's answer is clearly in the negative. ${ }^{50}$

Burhān al-dīn Ibrāhīm Ibn Muhammad al-Ḥalabī (146o-1549) shares these views in his Multaqā al-Abhur, that became an authoritative handbook of the hanafî law under the Ottomans. al-Halabī received legal training in the Mamluk sultanate and moved to Istanbul towards 1500. In the Ottoman Empire, he built a successful career, receiving appointments in elite teaching institutions, something that would soon become unusual for a Syrian. The Multaqā

\footnotetext{
46 Sarakhsī, Kitāb al-mabsūțt, XVI, 139.

47 al-'Aynī, Badr al-Dīn Maḥmūd Ibn Aḥmad (1361-1451): al-Bināya Sharh al-Hidāya, edited by Ayman Sālih Sha’bān, Beirut: Dār al-Kutub al-'Ilmiyya, 200o IX, 154.

48 Heyd, Uriel: Studies in old Ottoman criminal law, edited by V. L. Ménage, Oxford, 1973, 245.

49 al-Aynī, al-Bināya Sharh al-Hidāya, IX, 152-155.

50 Grignaschi: "témoignage des sujets non musulmans", 253-5. On Ebu's-su'ud's general mistrust towards dhimmī witnesses, Kermeli, Eugenia: "Ebussuud Efendi", in: Christian Muslim relations. Volume 7, Central and Eastern Europe, Asia, Africa and South America (1500-160o): a bibliographical history, Brill, Leiden; Boston 2015, 715-23.
} 
al-Abhur was completed in 1517. In the passage devoted to minority witnessing, he sticks to the hanafĩ orthodoxy as expressed by al-Aynī, in that dhimmīs can testify for or against mustāmmins "although not vice-versa" (dūn 'aksihi). If alḤalabī does not mention walāya, he seems to allude to the fact that everyone in society, even the most disgraceful, ranging from dhimmīs to mustā'mins and from sons of adulterers to the effeminate, can give testimony provided unequal power relations do not destroy the truth contained in it. A slave (mamlūk), therefore, cannot testify, although a manumitted servant (mu'taq) can be trusted as witness for or against his master (mu'tiq). Indeed and as we will see, Bailo Pietro Bembo complained in 1484 about a Venetian made prisoner on the basis of an affranchised slave's testimony in favor of his former master. Neither al-Ḥalabī considers religious enmity as a necessary obstacle to fair witnessing, a point previously raised by Ibn Qayyim. Inherent vices and corrupted morality, instead, disqualify potential witnesses, and al-Ḥalabī lists a long list mentioning from the most flagrant cases to pigeon raisers as well as music, chess and backgammon players. ${ }^{51}$

Even though the hanafi exception is generally accepted to have been adopted as a distinctive feature of Ottoman governance, this linear path between theory and practice was not applied in the case of the Franks. Although jurists did not accept Frankish testimony against local dhimmīs, rulers overthrew this claim by affirming that the mustā'min formed a single community with the Ottoman subjects of Christian and Jewish stock. ${ }^{52}$ Placing the Franks on the same legal footing as that enjoyed by the dhimmīs constituted an appalling disregard for jurisprudence and particularly for hanafì doctrine. The Ottoman official position is made clear in the Italian and French versions of

$51 \quad$ Pigeon raisers were often excluded from witnessing, probably due to the knowledge on their neighbors' lives they unlawfully acquire over rooftops, al-Ḥalabī, Ibrāhīm Ibn Muhammad (1460-1549): Kitāb Multaqá al-abḥur, edited by Wahbī Sulaymān Ghāwijī al-Bānī: Dar al-Bayrouti, 2005, 459-6o. The interdiction, however, lay its roots in Jewish law: Malka, Orit: "Disqualified Witnesses between Tannaitic Halakha and Roman Law: The Archeology of a Legal Institution", Law and History Review: 1-34. As for backgammon and chess players, they are usually targeted by the hanbalīs, Cook, Commanding right and forbidding wrong in Islamic thought, 93-96, 146.

$5^{2}$ "Il est intéressant de noter que le fiqh refusait catégoriquement aux étrangers (musta'minin) le droit de témoigner contre les dhimmi. Leur témoignage n'était accepté que dans les procès mettant en présence des parties appartenant au même pays (dar). La raison de ces limitations nous est indiquée par Sarakhsi, quand il insiste sur l'opposition entre le daru-l-islam, constituant une unité spirituelle et juridique si forte, en dépit de ses divisions politiques, qu'elle établissait un lien parmi les dhimmi eux-mêmes, et le monde étranger, dans lequel les Etats n'étaient basés que sur la violence (Sarakhsī Kitāb al mabsut).", Grignaschi: "témoignage des sujets non musulmans", 219-20. 
commercial treaties, but also in Turkish firmāns ranging from 1520 to as late as $1698 .^{53}$ When asked about the Bailo's right to summon Venetian witnesses to counter the claims of a hypothetical dhimmī, Ebu's-su'ud answered that no school of thought validated such testimony, adding that "in this regard the ahdnames convey traditional mistakes" and that the qādīs should ignore the clauses allowing mustāmmins to bear witness for or against dhimmīs, failing which they deserved to be removed from office. ${ }^{54}$ If it cannot be said that the Ottomans were in strict adherence to hanafi doctrine, nor can they be cast as mere pragmatists - an angle often adopted by commentators of the ahdnames and treaties with Muslims. Indeed, the Ottomans' decision to put the Franks on the same legal footing as their local coreligionists was applied to all merchant nations, even small ones, and upheld for over two centuries. By the same token, the tendency to invariably present the Ottomans as innovative and dynamic in their attitude towards institutions should be adopted with caution. Indeed, Grignaschi's assumption that the considerations mentioned above about harbīs and issues of evidence was a distinctively Ottoman trait is no longer tenable. We have seen in previous chapters that Mamluk thinkers such as al-Subkī were concerned with similar issues; the position of the hanafis and other schools were discussed in the 14th-century treatise on Siyāsa by Ibn Qayyim, and later thoroughly addressed by the hanafìs al-'Aynī and al-Halabī. The former, a native of 'Ayntab in southern Anatolia, was a Turkish-speaker who translated his own works from Arabic into Turkish and taught jurisprudence to several Turkish-speaking Mamluk sultans, whilst the latter pursued a career in Istanbul based on his prestige as a Syrian jurist. ${ }^{55}$ Naturally, Syria, to which European merchants flocked in great numbers throughout the long $15^{\text {th }}$ century, provided scholars with material for these fatwās and fiqh works, in the same manner that the region was host to major developments in the application of Mamluk Siyāsa. Conversely, and probably due to the quarrel between jurists and rulers on that point, not all hanafîs stuck to the same specific framework when dealing with diversity. Şeyhülislams such as Zakariyazade Yahya Efendi (1634-1643) and Menteshizade 'Abdu-r-Rahim Efendi (in office 1715-6) allowed cross-confessional dhimmī witnessing while excluding mustāmmins, whereas Zayn al-Dīn Ibn Ibrāhīm Ibn Nujaym (1520-1563), writing at a time when such controversial issues were only just emerging, and who thoroughly explored the

53 Ibid., 235, quotes a ferman adressed to the Lords of Samos, and the Treaty of Karlowitz, respectively.

54 Ibid., 253.

55 Marçais, W. (2012), al-'Aynī, Encyclopaedia of Islam, Second Edition, I:79ob. 
relationship between writing and testifying in his chapter on proof, prudently preferred to leave this question aside. ${ }^{56}$

\subsubsection{Foreign Unbelievers: Between Mistrust and Accommodation}

Probably due to the current emphasis on describing cross-confessional practices, often stemming from non-Muslim sources, we are getting used to a flexible and pragmatist interpretation of Ottoman governance. This was not the norm half a century ago, and Grignaschi, by contrast, held the assumption that ḥanafĩ doctrine constituted a major vector in understanding Ottoman legal attitudes. Most schools of law, including some hanafîs, mistrusted dhimmī testimony, however jurists were open to accepting it for the sake of convenience (istihsaan, or juristic discretion). Accordingly, so too the Ottoman legal order must have sought a balance between these two principles. Grignaschi initially speculated on the apparently specifically Ottoman tendency to allow dhimmīs the right to produce proof for reasons of necessity, focusing on legal situations where Islamic laws on evidence were strictly applied, even if it conspired to curtail the spread of Islam. ${ }^{57}$ The demonstration of this claim, however, relied on extreme examples, such as the fatwā by Çatalcalı Ali Efendi (1631-1692) reasoning that, if a Christian freed his Muslim slave before two Christian witnesses, the latter could not be proved to be free and should remain therefore in slavery. Initially Grignaschi's had stressed how Ottoman law extended to dhimmiss the same legal reasoning adopted for issues concerning Muslims, a viewpoint shared by contemporary legal historians. ${ }^{58}$ Not necessarily in contradiction with this, Grignaschi then adopts a more critical tone, claiming that Ottoman jurisprudence was dominated by a second principle: mistrust for the dhimmīs' ability to testify the truth. As regards regulations on matters of debt, Grignaschi focused on the principle that Muslim creditors enjoyed precedence over their non-Muslim counterpart, although he acknowledged that such a privilege was not relevant when the witnesses were Muslim, irrespective of the parties' religion. Yet as we shall see in the case of bankruptcy studied later in this chapter, in claims for debt the biases against non-Muslims provoked attitudes that cannot be easily explained by jurisprudence alone. Just as dhimmīs' rights were extended to mustāmins, in disregard for the rules of fiqh, during

\footnotetext{
$5^{6}$ Ibn Nujaym, al-Ashbāh wa-al-nazāàir, 257-293, Grignaschi: "témoignage des sujets non musulmans", 234.

57 Heyd, Studies in old Ottoman criminal law, 186, on istiḥsān, Kermeli: "Ebussuud Efendi", elaborates on Ebu's-su'ud's accommodation for neighborly relations, and for family law. Imber, Ebu's-su'ud: the Islamic legal tradition, 108-9.

Müller: "Non-Muslims as part of Islamic law," 28.
} 
the Priuli lawsuit Franks seem to have been denied the right to have recourse to their own Muslim witnesses.

Legal historians debate over the justice that was delivered at the qādī courts. For some, decisions were dictated by the need to maintain the rule of law, with no biases against the litigants' social condition. For others, gender and race prejudices were strong, and judges tended to validate testimony from witnesses of a privileged social background. ${ }^{59}$ My analysis of Ottoman intervention in cross-confessional issues aims to distance itself both from claims of mere pragmatism, and an excessive reliance on jurists' law. Rather, with all of its inconsistencies, attitudes towards unbelievers, maintained over time, signal the existence of a conscious policy to attempt to deal with the affairs of the mustā’mins.

Born in Cairo under Ottoman rule, and the author of an important work on hanafî jurisprudence, Zayn al-Dīn Ibn Nujaym (1520-1563) combined both the new attitudes towards written evidence addressed in section 2.5, and suspicion towards minorities as actors of the legal system. Ibn Nujaym mistrusted minority witnessing, while maintaining an open attitude towards the widespread use of hujjas. ${ }^{60}$ To justify reliance on written artifacts, he pointed to the use of safe-conducts by harbīs: deeds of appointment (berats), granted to ḥarbīs accounted for the legal status of the holder (hâmil), and, since these documents referred in the last instance to the head of the community, they were endowed with the trust granted to official documents, and hence should be equated with the persons of officials. ${ }^{61}$ Similarly to the Mamluk case examined in the previous chapter, where courtier-witnesses bore testimony for crossconfessional transactions, merchants and bankers -Ibn Nujaym goes- rely on the registering of transactions by these courtiers, and hence their daftars should be admitted as proof. Ibn Nujaym, it has been noted, counts among the earliest scholars exhibiting an open attitude towards custom as an important vector in Islamic law, hence anticipating nineteenth-century developments in this much-disputed matter. ${ }^{62}$ Written evidence, Ibn Nujaym argued, was always more trustworthy than a witness who claimed to no longer remember

59 Hosainy: "Ottoman legal practice and non-judicial actors in Seventeenth-century Istanbul", Wilkins: "Witnesses and Testimony in the Courts of Seventeenth-Century Ottoman Aleppo".

6o Johansen, "Formes de langage", 369, Ayoub, Samy, “"The Sulțān Says”: State Authority in the Late Hanafî Tradition", Islamic Law and Society 23 (2016), 239-278.

61 Ibn Nujaym, al-Ashbāh wa-al-nażāì 'alá madhhab Abī Hanīfah al-Nu'mān, 257.

62 Francesca, Ersilia: "L'applicazione del diritto islamico nell'impero ottomano (1500-180o)", in: Storia dell'Europa e del Mediterraneo: Culture, religioni, saperi, vol. XI (II della sezione Età moderna), edited by Roberto Bizzocchi, 475-523, Roma: Salerno editrice, 2011. 
the facts, since good faith should be assumed for those who bore testimony, and not for those who admitted not knowing. Moreover, Ibn Nujaym seems to have mistrusted the well-known principle kitäbun yushbih kitäban - "one writing looks like another," and therefore cannot be trusted. "How, then, shall we proceed?" he asked: by taking responsibility for the writing of only one's own deeds. The hujja could thus be counted among the standard types of sound proof, he reasoned, and-according to Ottoman practice examined in Chapter Two-what had been accepted by a judge during the hearings and had been included in his sijill should in theory allow the hujja-holder to enjoy their rights, in and out of court. ${ }^{63}$

Ibn Nujaym's tone, favorable towards written evidence, changed however when addressing the issue of who could give testimony. The unbeliever's testimony could be accepted for cases where mixed dealings had led one of the parties to appoint a commission agent of another confession, however as was the case for matters of debt, minority witnessing was only accepted if it favored Muslim partners and creditors. Several times, Ibn Nujaym equated unbelievers with the deaf and children, and insisted that witnessing should not be accepted when it came from an individual unable to claim a clear religious status. ${ }^{64}$ As Giovanni Dario was reminded by the pashas, witnesses needed to be known to the community, together with their families. Ibn Qayyim and a number of other theorists held that the hanafi exception was generally applicable, except for cases of conversion. Generally, the probative effectiveness of a statement was dependent upon the religion of the witness, and not on that of either party; in support of which Ibn Nujaym cited the usual case of cross-confessional ownership of slaves, deathbed conversion to Islam, etc., accepting the principle that Muslim witnesses needed to be trusted, even in cases in which their testimony proved to be prejudicial to the interests of Islam. This was the case, for example, for a Christian who had had three sons, two of which were Muslims and who could witness to the fact that the man had died a Christian. If a third, Christian son swore that he died a Muslim, he was not to be trusted. ${ }^{65}$ In al-Ashbāh wa-al-Nazääir, Ibn Nujaym adopts an open-minded attitude towards the use of writing for probative purposes, however he is reluctant to regard non-Muslims as actors in the legal system. He also prefers not to comment on

63 Ibn Nujaym, al-Ashbāh wa-al-naz̄āir 'alá madhhab Abī Hanīfah al-Nu'mān, 293.

64 Heyd, Studies in old Ottoman criminal law, 245, Ibn Nujaym's opinion in this regard is shared by Ebu's-Suud, who ruled that an infidel who did not frequent his house of prayer was not competent to testify, Ibn Nujaym, al-Ashbāh wa-al-nazāäir 'alá madhhab Abì Hanīfah al-Nu'mān, 280.

65 Ibn Nujaym, al-Ashbāh wa-al-nazāàir 'alá madhhab Abī Hanīfah al-Nu'mān, 473. 
the status of the mustāmmins. Ibn Nujaym's work is representative of Ottoman intervention in the legal system, but also suggests that government-sponsored practice may have influenced legal reasoning, and not the other way around.

Judging by its longevity, the rigid application of the biases, and particularly against Christian witnesses, could be labeled an Ottoman orthodoxy. However, this official doctrine needs to be interpreted against the backdrop of actual choices and policies, and not solely against the writings of jurists. As argued by Snjezana Buzov, such orthodoxy was tautological when applied to the decisions made by a Muslim ruler, who asserted his commitment to implementing the rule of law. In the following pages I will refrain from adopting either a purely pragmatic, or a strictly juristic view of Ottoman governance amidst diversity. Although fiqh and practice were obviously linked to each other, the field of legal relations with foreigners was rife with conflict, and Ottoman rulers made their own choices, which were not necessarily always in harmony with the advice of jurists. In the case of Ebu's-su'ud, usually described as a pragmatist, and considered to be the jurist who brought kanun in agreement with sharīa, it is precisely on the issue of Frankish witnessing that he departs from government-sponsored practices. ${ }^{66}$

Ottoman jurists dealing with unbelievers were actually used to tackling issues of inheritance and debt. Muslims were not often present at a Christian's deathbed, nor did they attend their weddings, and for this reason dhimmī witnessing was actually necessary when it came to claims of inheritance, succession, or determining relations of kinship. Unbelievers were heard for reasons of equity or as an act of grace (istiḩsān), or due to necessity (ḍ̂arüra). ${ }^{67}$ A classic example was the inheritance of a deceased dhimmī; in the absence of righteous heirs, these estates were reclaimed by the treasury, the Islamic Bayt al-māl; thus, dhimmì witnessing was indispensable for proving intracommunal matters, such as those pertaining to family law. Hence sharīa biases against dhimmì witnessing were mitigated by the principles of istihsān, as they had been under the Mamluks in texts invoking the mașlahat al-Isläm. A case concerning the estate of a merchant from Dubrovnik is illuminating as regards commercial litigation. The so-called 'Dubro-venedik' case, tackled in Ebu's-Su'ud's legal writings, marks the limits to the application of istihsān exceptions, and to the Ottoman authorities' willingness to accommodate for non-Muslim testimony. Based on broad consensus by scholars, Ottoman

66 Buzov, The lawgiver and his lawmakers, 16. Significantly, Kermeli: "Ebussuud Efendi", hesitates between characterizing Ebusuud as a pragmatic thinker or as a conservative as regards inter-faith relations.

Ibn Nujaym, al-Ashbāh wa-al-nazā̇ir 'alá madhhab Abì Hanīfah al-Nu'mān, 268. 
authorities had traditionally allowed dhimmīs to testify for the property left by a deceased coreligionist. However, a decree issued in 1543 apparently contradicted this right, and triggered a famous fatwā by Ebu's-Su'ud. In that year, after the death of a merchant from Dubrovnik, the case was brought to the attention of the Porte, which issued a request to look for Muslim witnesses for the merchant's last will. The Dīvān's request, which was in contradiction with both scholarly consensus and actual court practice, alarmed the qadis, who consulted Ebu's-Su'ud on whether the qadis were expected to continue applying the istihsān procedure-commonly accepted for family and probate issues - or whether they should ask for permission from the Porte. Ebu's-su'ud answered that the decree was an ad hoc measure, due to suspicion of fraud in the witnesses' depositions, and therefore should not be applied to future cases. Contemporary commentators suggest that the merchant was a mustā'min who died in the Ottoman Empire; the fact that he was not a dhimmì but a foreigner enjoying a lower legal status may have motivated the suspension of the istihsān procedure. ${ }^{68}$ Be that as it may, the episode is telling in that it reveals the constraints Ottoman rulers could impose on the labor of jurists.

The principle of istihsān was in particular frequently resorted to in the European areas under Ottoman dominion, for issues concerning payments to timar-holders, and more generally, those revolving around the property of land. In claims over debt, last wills, and other fields, there was room for an accommodating interpretation of evidentiary rules. However, this cannot simply be attributed to the fact that the Empire extended over regions largely inhabited by non-Muslims; indeed, it was the norm to give priority to Muslim witnesses in the late Ottoman Rumelia courts, such as those of seventeenth-century Sofia. ${ }^{69}$ Moreover, it has to be noted that the decision to accommodate for dhimmi witnessing occurred at the height of Ottoman military strength, so it can hardly be viewed as a concession granted according to balances of power. In other European principalities, accommodation affected other aspects of procedural law: In Dubrovnik, Bulgaria or Serbia, Ottoman qadis accepted to consider vernacular forms of contracts and even collaborated with dragomans knowledgeable in Islamic law. ${ }^{70}$ However, to

68 Imber, Ebu's-su'ud: the Islamic legal tradition, 108-9, Van den Boogert, The Capitulations and the Ottoman Legal System, 174-5, Grignaschi: "témoignage des sujets non musulmans", 241-2, Gökbilgin: "La preuve et le témoignage dans la jurisprudence des Fetva d'Ebussud".

69 Gradeva, "Orthodox Christians in the Kadi Courts: The Practice of the Sofia Sheriat Court, Seventeenth Century", Speros Vryonis, Jr., "The Byzantine Legacy and Ottoman Forms", Dumbarton Oaks Papers Vol. 23/24 (1969/1970), 251-308.

70 Fotic, Aleksandar: 'Non-Ottoman Documents in the Kadis,' Courts (Moloviya, Medieval Charters): Examples from the Archive of the Hilandar Monastery (15th- 18th C.)", 
the difference of dhimmīs, accommodation never governed the relations with mustämins, who had nevertheless to deal with many obstacles to the validity of their testimony. Minority testimony in all other matters, as at the qadi courts, was completely valueless, and in the context of large communities of dhimmīs and mustāmmins, for Frankish merchants the 'bronze wall' rose higher and higher, with no apparent mechanism to balance out its effects, as was the case for dhimmīs with the istihsān procedure. This is at least a late-nineteenth century reading of the problem, such as that advanced by the Neapolitan jurist Francesco Paolo Contuzzi. In his book, which is significantly enough devoted to the consular institutions, he notes that: "the mustāmins can be witnesses only for their internal disputes, and when they belong to the same nation. The testimony of a mustāmin against a Muslim is not accepted. Here emerges a bronze wall, raised between Muslims and Christians." ${ }^{71}$

To be sure, the cumbersome nature of legal bans took a heavy toll on the interactions between Muslims and foreign unbelievers, be they borderland issues or simply market transactions. Yet in spite of these strong prejudices, mechanisms did exist to unblock the legalistic catch-22 imposed upon the Franks. Indeed, the Ottomans adopted their own, opener attitudes towards written evidence and, whatever the motivations behind the adoption of these practical measures, they served to mitigate the effects of the legal biases against minority witnessing. Most notably, I will be addressing a policy that has largely passed under the radar, and that allowed Franks to rely entirely upon documents for their legal defense, and which I refer to hereinafter as the "ban on Muslim witnesses." Although it marked a clear division between Islam and unbelief, combined together, Ottoman legal attitudes created a legal framework that was able to guarantee the striking of deals, supported by the notarizing functions of the qadi, and made it possible to have recourse to cross-confessional witnessing to support agreements between Europeans and local Jews and Christians. Ottoman attitudes did not simply adapt to the standard solutions provided by hanafí jurists, and even when they departed from jurisprudence Ottoman policies were implemented without necessarily challenging fiqh. While tolerating business and daily exchanges, the Ottoman

in: Frontiers of Ottoman studies (Vol. 2), edited by Colin Imber, Keiko Kiyotaki, et al., London, 2005, 63-73, Zecevic, "Translating Ottoman Justice: Ragusan Dragomans As Interpreters of Ottoman Law".

71 Contuzzi, Francesco: La istituzione dei consolati ed il diritto internazionale europeo nella sua applicabilità in Oriente, Naples: E. Anfossi, 1885, 145. 
sultan was able to present himself as a guarantor of the supremacy of Muslims as legal actors, and as an enforcer of the rule of law.

Three months after his return to Venice, in April 1522, the ambassador Marco Minio had his final relazione read before the Senate. Venice and the Porte were by that time engaged in a diplomatic effort to define the conditions of the mustā'min presence in post-conquest Egypt and Syria. To the two agreements drafted in barely five years, Minio added the clauses contained in the new treaty issued in 1521 . The Venetians had placed a demand on the negotiating table, asking that, for disputes concerning the return of Frankish captives "Christian witnesses should be accepted."72 This request represented a challenge to one of the founding principles of the law on evidence, and one can hardly believe the Venetians' request was advanced out of pure ignorance of this. To include this issue in the agenda, Minio adds, was the doge in person. Needless to say, the Ottomans avoided giving a straight answer, suggesting that such disputes needed to be discussed at the Dīvān, where the Bailo's word would be taken into consideration - an issue to which I will return. As I have mentioned earlier, such a naive request was never raised by Venice during the Mamluk period, although, significantly enough, the less-experienced Florentines did so in 1481. It is noteworthy, then, that the Venetians felt the need to bring minority witnessing up so soon after the conquest of Egypt and Syria. Without giving much hope to the Venetian negotiators, the Ottomans made clear that, although minority witnessing was non-negotiable, further accommodation at the Dīvān could be reached, particularly if the Bailo himself personally vouched for the Venetian party. In light of the conversations held between Giovanni Dario and the pashas thirty years previously, there is little doubt that the allegedly orthodox approach to non-Muslim witnessing had a directed influence on, if not entirely governed, relations with the Franks.

The strict adherence of Ottoman governance to the doctrines of the hanafis is patent as regards the adoption of the hanafĩ exception. As eyewitnesses to this legalistic approach to governance, the Bailos and the ambassadors noticed the official sponsoring of hanafi views on proof and procedure, and the empowerment of ḥanafî ‘Turkish' qadis over preexisting local judiciaries. They

72 "Il terzo, che se uno mercadante veneziano fosse convenuto davanti il cadi per qualche differenzia. non possa il cadi giudicarlo non essendo il suo dragoman li presente. Un altro capitolo è delli schiavi, circa la sua ricuperazione, il qual non ho potuto far che fosse posto secondo la intenzione di Vostra Serenità, cioè che fosse creduto a' testimonii cristiani," Relazioni degli ambasciatoriveneti al Senato, Serie III, Volume III, 88. Theunissen, OttomanVenetian Diplomatics, $415-36$. 
commented on the summary nature of justice, the lack of interest paid to written deeds, but above all on the complex nature of the Dīvān itself, where there was no clear division between state and purely legal affairs. As Bailo Barbarigo put it in the 155os, "they deal with all requests (arz); that is, lawsuits, petitions, along with all sorts of private disputes and state affairs." ${ }^{73}$ Venetian diplomats, whose talkative dispatches provide us with a good deal of insider information, were firsthand witnesses to this hanafĩ orthodoxy, as well as being directly involved in accommodations, negotiations, and the quest for loopholes in the bronze wall of sharīa norms. ${ }^{74}$

However, what the Bailos perceived as an Ottoman orthodoxy needs to be read against the backdrop of these apparent contradictions and exceptions to the general rules. Mirroring the two vectors governing, in theory, the handling of proof and unbelief, two distinctive features characterized, in practice, early Ottoman attitudes towards the Franks in the court and at the marketplace. The first is the departure from hanafì legal texts in one important respect; in their disregard for the hanafì principle that mustā̉mins could not testify against dhimmīs. This was an important footnote to the hanafì masters, and as pointed out by Grignaschi, Ebu's-Su'ud, the champion of Ottoman legal orthodoxy, explicitly raised objections against the sultans' actions on this point. ${ }^{75}$ As expressed in the jurists' jargon, the official position held by Ottoman rulers was that all unbelievers constituted "a single nation." However, by affirming this, they departed from the revered opinions of the hanafis. On similar grounds, a second feature that marked all kinds of exchanges in practice is the unexpected ban on Muslim witnesses against Franks. Ad hoc rearrangements of the legal system were found for important locations such as Aleppo, where a specific ferman inhibited the general legal framework enforced in other cities of commerce.

73 "dove giunti, subito seduti li pascià, si appresentano in mano di Rusten tutti li artz, cioè querele, suppliche ed ogni altra sorte di scritture appartenenti cosi a materie e cause private come a, cose di Stato", Relazioni degli ambasciatori veneti al Senato, Serie III, Volume III, $155^{-6 .}$

74 Graf, Tobias P.: The Sultan's renegades: Christian-European converts to Islam and the making of the Ottoman elite, 1575-1610, Oxford-New York, 2017, 6.

75 Fatwās issued by Ebu's-Su'ud published in Friedrich Selle, Prozessrecht des 16. Jahrhunderts im Osmanischen Reich. Auf Grund von Fetwas der Scheichülislame Ebüssuud und anderer unter der Regierung des Sultans Süleiman des Prächtigen, Wiesbaden, Harrassowitz, 1962, 41 (91), §§ 10-11, and Paul Horster, Zur Anwendung des islamischen Rechts im 16. Jahrhundert: die "juristischen Darlegungen" (Ma'rüżāt) des Schejch ül-Islam Ebū Su'ūd (gest. 1574), Stuttgart, Kohlhammer, 1935, 53 (91), cited by Heyd, Studies in old Ottoman criminal law, 245, and n. 7 . 
At some point in the early sixteenth century, the Ottoman chancery started granting a privilege that allowed Franks to defend themselves in court by exhibiting written deeds, more specifically a hujja (Tr. hüccet) produced by a qadi. Parallel to this measure, and more importantly, Muslim witnesses could not be heard to counter the contents of these legal certificates. As pointed out by Maurits van den Boogert, the very idea of preventing the oral performance of Muslims at court is, in principle, at odds with Islamic laws of evidence. Evidently, the argument could be turned the other way around, as a hüccet was by definition an agreement supported by Muslim witnesses. And indeed, this counter-argument was not unknown to late medieval commentators; according to Ibn Qayyim and his master Ibn Taymiya, if a document was known to be authentic, a judge could rely upon it for a ruling, since "writing is the expression of utterings and ultimately, of willingness and determination." 76 In choosing to issue such a ruling, the Ottomans probably had in mind the claims of contemporary jurists such as Ibn Nujaym, to whom the hujja counted among "sound forms" of proof (bayyina 'àdila), together with confession (iqrār), the defendant's refusal to take an oath, the oath itself, collective oaths (qasāma), the judge's personal knowledge of facts, or reasonable assumptions (qarina qātịa). ${ }^{77}$ For European commentators and scholars focusing on the external manifestations of this practice, such a privilege departed from sharīa principles. From a juristic perspective, however, jurists such as Ibn Qayyim or, in Ottoman times, Ibn Nujaym refashioned the argument in favor of written evidence, on the grounds that words such as bayyina and hujja, although usually understood to mean, respectively, 'oral' and 'written' witnessing, actually carried the more abstract notions of 'proof' of 'arguments of authority', and that the Qur'ān did not intend the term bayyina to refer exclusively to testimony. ${ }^{78}$

Whatever its origins, the move to grant Franks the right to present hujjas as proof should be taken against the backdrop of a more generalized Ottomansponsored practice; that is, that any business deal-although it continued to be an oral agreement freely reached by two parties, needed to be supported by a written deed, a hüccet registered before a hananầ qadi and subscribed by witnesses. ${ }^{79}$ Of course, this was nothing entirely new: we know that some

76 Ibn Qayyim al-Jawzìyah, al-Ṭuruq al-ḥukmīyah, 549.

77 Ibn Nujaym, al-Ashbāh wa-al-nazā̄ir 'alá madhhab Abī Ḥanīfah al-Nu'mān, 293, Johansen, "Signs as Evidence", 336.

78 Bechor, God in the Courtroom, 348.

79 Baldwin, Islamic Law and Empire in Ottoman Cairo, 35, and n. 16 illustrates the process of contract registration, on the basis of the Cairo court registers. 
contracts were registered in court under the Mamluks, presumably in a very similar manner to that now rendered compulsory by the Ottomans. ${ }^{80} \mathrm{We}$ also know that under the Mamluks, Franks and Muslims had recourse to the notary-witnesses and, when available, to the Latin notary, although we have no references to mixed commercial contracts registered at the courthouse.

The new registering policy promoted by the Ottomans had the effect of empowering the hanafî, Ottoman-appointed qadis, as they were endowed with the monopoly of certification (tasjil $)$. In addition, the measure was applied to the entire territory of the Empire, and affected faraway commercial hubs such as 16th-century Jedda and Mecca. In these cities, although the parties had recourse in the first place to their own witnesses and qadis, they were later compelled to have their acts registered before the hanafi-sometimes referred to as 'Turkish'-judge. This meant that the hanafi judge had the last word in much-disputed cases, particularly for issues related to the endowment of religious foundations or last wills. And indeed, the descriptions of Mecca given by Jār Allāh Ibn Fahd (1486-1547) place the hanafĩ chief qadi Badī` al-Zamān Ibn al-Ḍayā' at the center of many quarrels, and portrays him manipulating their legal outcome by imposing his own, corrupt witnesses for the final drafting of hüccets. ${ }^{81}$

The treaty signed between the Ottomans and Florence in 1488 does not make any mention of the interdiction on testimonial proof. ${ }^{82}$ Similarly, the 'Egyptian' treaty underwritten with Venice in 1517, drafted in Arabic, adheres to traditional methods of notarization - although, it could be argued, it is a treaty that should be interpreted in the context of Egyptian judicial custom. According to Nicolas Vatin, the latter was a provisional ahdname issued when the effective incorporation of Egypt into the Ottoman Empire had not yet been decided. ${ }^{83}$ Gladys Frantz-Murphy asserts that the text is "Mamluk," meaning probably that it was drafted by the Mamluk chancery, or that it followed conventional Mamluk patterns of treaty-writing. ${ }^{84}$ Be that as it may, the 'Egyptian'

8o Rapoport, "Legal Diversity in the Age of Taqlid: the Four Chief Qadis Under the Mamluks", 222.

81 Ibn Fahd, Nayl al-Muná bi-Dhayl Bulūgh al-Qurá, 184-5, 208-9, 308-10.

82 Müller, Joseph: Documenti sulle relazioni delle città toscane coll' Oriente cristiano e coi Turchi fino all'anno MDXXXI, Firenze: M. Cellini e c., 1879.

83 Moritz, Bernhard: "Ein Firman des Sultans Selim für die Venzianer vom Jahre 1517", in: Festschrift Eduard Sachau, Edited by G. Weil, 422-443. Berlin: Georg Reiner, 1915, Theunissen, Hans, "Cairo Revisited (I): Four Documents Pertinent to the OttomanVenetian Treaty of 1517", Electronic Journal of Oriental Studies 2 (1999).

84 Frantz-Murphy, "Identity and Security in the Mediterranean World ca. AD 640-ca. 1517", 256, n.16. 
ahdname, whose terms seem to have been limited to stipulating Venetian trade in Egypt, reflects the most pressing priorities of the Ottoman reform agenda. The 1517 text makes it clear that the Siyāsa courts were no longer part of the adjudication system, although it does not yet concern itself with the other procedural aspects of mixed trials.

Early Ottoman treaties-that is, those signed before the 1530s-clearly evoke the continuity of traditional patterns of notarization, with contracts underwritten before traditional notary-witnesses. In the same fashion, nothing is said about notarizing at the qadi's court in the 1478 ahdname signed with Venice. ${ }^{85}$ The Egyptian treaty stresses continuity as regards how business deals should be concluded, and on several occasions mentions the port's notary-witnesses (shuhūd), thus confirming that notary-witnesses attached to the customs administration, were still an option. However, the document quite insistently makes a clear distinction between Franks, Christians (nașrān̄ ), Jews and Maghrebis. Moreover, it marks a growing division of labor between the agents of notarization and those entrusted with linguistic mediation, the dragomans, two tasks whose contours had been growing more and more blurred in the late Mamluk years. The ahdname states that if a dragoman has recourse to the shāhid to draw up a deed, the latter should not be prevented from doing so. This probably means that deals were often concluded solely in the presence of a translator, but that in some cases one of the parties insisted on having the deal notarized by a proper shāhid. In contrast with the Egyptian, Arabic treaty issued immediately after the conquest, neither the second, more official Turkish treaty signed by ambassador Alvise Mocenigo in 1517, nor the 1521 ahdname mention issues of notarization, and seldom do they refer to legal forums for disputes. ${ }^{86}$ In this, the Ottoman chancery marked a break with the Mamluk past, increasingly concerned as it was throughout the $15^{\text {th }}$ century with adjudication norms and with the securing of deals.

The ban on Islamic witnesses for mixed trials is mentioned in the treaty with François I in 1535 , but not in the treaty concluded a few years before, in $1528 .{ }^{87}$

85 Wright, Diana Gillilandand Pierre A. MacKay, "When the Serenissima and the Gran Turco Made Love: The Peace Treaty of 1478”, Studi Veneziani 53 (2007), 261-277.

86 Theunissen, Ottoman-Venetian Diplomatics, 400-36.

87 Saint-Priest, François-Emmanuel Guignardand Charles Henri Auguste Schefer: Mémoires sur l'ambassade de France en Turquie et sur le commerce des Français dans le Levant, Paris,: E. Leroux, 1877 345-353, Charrière, Ernest: Négociations de la France dans le Levant, ou Correspondances, mémoires et actes diplomatiques des ambassadeurs de France à Constantinople, etc. Vol. I, Paris: Imprimerie Imperiale, 1848, 287, Jensen, De Lamar, "The Ottoman Turks in Sixteenth Century French Diplomacy", The Sixteenth Century Journal 164 (1985), 451-470, 453-5 and n. 18. 
Thus, if this chronological speculation is correct, the ban on Muslim witnesses against Frankish merchants crystallized in chancery artifacts sometime in the early 1530 . This would account for the general climate of confusion surrounding the Priuli bankruptcy dealt with at the end of the present chapter, and for the hesitancy of Western merchants to register contracts in and out of court. When Marco Priuli died in prison in Damascus, the executors of his will found both Arabic contracts and deeds drawn up by the Venetian notary in Syria, however his heirs had difficulty backing their claims due to the absence of contracts properly registered at the qadi courts. Encoded in the much-disputed treaty with France in 1535, is the first formulation of a ban on Muslim witnesses for mixed cases:

Item. Que en cause civille contre les Turcqs, carrachiers ou autres subgets du Grand Seigneur les marchans et subjectz du Roy ne puyssent estre demandez, molestez ne jugez si lesdicts Turcqs, carrachiers et subgetz du G. S. ne monstrent escritures de la main de l'adversaire ou coget (c'est instrument) du caddi, baille ou consul, hors de laquelle escriture ou coget, ne sera vallable ne receu aucun tesmoignage de Turcq, carrachiers ne autre en quelque part que ce soit de testât et seigneurie dudict G. S. et les caddi, sousbassy ne aultres ne pourront ouyir ne juger lesdicts subgetz du Roy sans la présence de leur dragoman. ${ }^{88}$

We can only speculate as to why the lawmakers felt it necessary to make the norm explicit in treaties signed with inexperienced trading nations, such as Tuscany and France, but not with historic partners such as Venice. France, although it was an important trading nation by that time, was a newcomer to Middle Eastern diplomacy. In any case, the right to prove acts with registered contracts was rendered explicit in all following 16th-century French capitulations, and in those underwritten with another rising commercial power, the Grand Duchy of Tuscany. Some authors have cast doubt on the 1535 treaty's authenticity, an argument based on stylistic grounds, however De Lamar Jensen believes that the text reflects the momentum attained by Franco-Ottoman relations at the time of the alliance between Süleyman I and François I. ${ }^{89}$ Generally considered to be a concession to France, the early formulation of the ban on Muslim witnesses could indeed support this idea, together with the fact

88 Saint-Priest and Schefer, Mémoires sur l'ambassade de France en Turquie et sur le commerce des Français dans le Levant, 356.

89 Jensen, "The Ottoman Turks in Sixteenth Century French Diplomacy", 455. 
that the treaty also mentions the Ottoman position that the mustā'min's word could be used against that of a dhimmī. ${ }^{90}$

Whatever its origins, the ban on Muslim witnesses against Frankish litigants slowly crystallized in Ottoman chancery documents, and invariably appears in the extant translations of the treaties. The French version of the 1535 treaty stipulates that only contracts registered by the "caddi, baille ou consul" should be counted as valid, although as time went on, the phrasing did away with references to any notarial artifact other than the qadi-registered hüccet, as is the case and in 1569, where the text appears to refer to the validity only of written deeds registered at the courthouse. ${ }^{91}$ Incidentally, the Turkish version of the 1569 treaty just assumes that in case where no documents are available, the parties will naturally tend to produce false witnesses (şāhid-i zūrr), an important point to which I will return. ${ }^{92}$ More explicit provisions excluding Muslim witnesses were laid down in a draft treaty between the Porte and Tuscany in 1578, or in the French capitulations of 1597:

Che nessuna persona possa astringier per debito subditi o mercanti delli Stati del Granduca di Toscana a nessun tribunale, se gia non fussi scrittura apparente, o sigillo del Cadi, non occorrendo in tal caso testimonianza di persona. ${ }^{93}$

Que les François, leurs consulz et interprettes ou ceux des lieux qui deppendent d'eux ayent en leurs ventes et achaptz, pleigeries et tous autres pointz d'en faire acte devant le cady, au deffaut de quoy, ceux qui

9o "Item. Que en causes criminelles, lesdits marchans el autres subgetz du roy ne puyssent estre appelles des Turcqs, carrachiers ne autres devant les caddis ne autres officiers du Grand Seigneur, et que lesdits caddis ne officiers ne les puyssent juger; ains, sur l'heure, les doyvent mander a l'excelse Porte, et en l'absence d'icelle Porte au principal lieutenant du grant seigneur, Ia où vaudra le tesmoignage du subget du roy el du carrachas du Grand Seigneur l'un contre l'aultre." Charrière, Négociations de la France dans le Levant, 287-88.

91 Saint-Priest and Schefer, Mémoires sur l'ambassade de France en Turquie et sur le commerce des Français dans le Levant, 370, n.6.

92 "Frānça ve aña tābi‘ olan yerlerüñ tācirleri ve tercümānları ve ḳonsōlōsları memālik-i maḥrūsemde bey ü şirā ve ticāret ü kefālet huuṣūṣunda ve sāiir umūr-ı şer'iyyede kạạ̣īye varub šebt-i sicill étdürüb veyā hüccet alalar. Șoñra nizā‘ olursa sicille veyā hü̈cete nażar olınub mūcibi ile 'amel olına. Bu ikiden biri olmayub mücerred şāhid-i zūr iḳāmet étmekile hilāf-ı şer` nesne da'vā éderlerse mā-dām ki ḳạ̣īlerden hü̈ccetleri olmayub ve yāhuūd sicillde muḳayyed bulınmaya anuñ gibilere tezvīr étdürilmeyüb hilāf-ı şer‘ olan davāları istimā' olınmaya," Paris, BNF, DO, Ms. Turc 130, f. 2r-8r, transcription courtesy of Güneş Işiksel, $4 \mathrm{r}$.

93 Camerani, Sergio, "Contributo alla storia dei trattati commerciali fra la Toscana e i Turchi", Archivio Storico Italiano 47 (1939), 83-101, C. 28, 100. 
auront quelque prétention contre eux ne le faisant apparoir par constract publicq enregistré au lieu de nos juges voullans prendre tesmoings, voulions et commandons qu'ils ne soient escoutez, ains soit donné foy aux contracts passés devant noz juges ou, n'y en ayant d'enregistré, que les demandes ne soient adjugées; et se tienne la main qu'il n'arrive chose contre la sacrée justice. ${ }^{94}$

The ban on Muslim witnesses in absence of documentary evidence gradually consolidated into a general principle governing relations with all Frankish nations - even, as we shall see, with Venice, in whose treaties such stipulations were previously omitted. The ban found its way into Ottoman-Polish diplomatic practice for the first time in 1553 , and then again in four successive treaties underwritten during the 16 th century. ${ }^{95}$ As a basic mechanism that underpinned the enforcement of transactions, it is mentioned in French capitulations as late as 1740. ${ }^{96}$ Timur Kuran reports the case of the English ambassador Finch (166o-1669) vs. the Iraqi merchant Mehmet, in which the former brandished the Ottoman-English capitulations, stating that only hüccet-supported claims could be advanced against Franks. Mehmet lacked valid documentation, and as a result the case was thrown out on procedural grounds. ${ }^{97}$ Similarly, in order to back his claims against an Ottoman Jew, an English subject produced a decree by Sultan Mehmet IV, and supporting fatwās by two şeyhülislams; ultimately, the Ottoman subject was unable to produce valid hüccets to defend his case. ${ }^{98}$ Kuran has found similar cases spanning several decades in the late 17th century. It should be noted, however, that the ban clause was conversely neither mentioned in the Venetian treaty of 1575 , nor in that underwritten in 1619. Similarly, the ahdname of Osman II (ruled 1618-1622) deals extensively with the role of witnesses and cross-confessional relations, but is silent on the ban on Muslim witnesses, and makes no reference to the need to register transactions, the very pillar of mixed deals under the Ottomans. ${ }^{99} \mathrm{In}$

94 Saint-Priest and Schefer, Mémoires sur l'ambassade de France en Turquie et sur le commerce des Français dans le Levant, 406-7.

95 Kołodziejczyk, Dariusz: Ottoman-Polish diplomatic relations (15th-18th century): an annotated edition of 'ahdnames and other documents, Leiden; Boston: Brill, 2000 241, 258, 277, 292, 311, 322 .

96 Contuzzi, La istituzione dei consolati ed il diritto internazionale europeo nella sua applicabilità in Oriente, 205.

97 Kuran, The Long Divergence, 228-9, 339, n.1.

98 Ibid. 339, n.2.

99 Mumcu, Serap, "1619 il trattato di pace fra l'Impero Ottomano e la Serenissima Reppubblica Ahidname di Osman II (electronic article)", https://www.academia.edu/26041394/ LAhidname_di_Osman_II, last accessed June 2019 . 
the Treaty of Passarowitz (1718) the ban is implicit, suggesting that disputes are to be resolved through the examination of documents, and only secondarily through the hearing of witnesses. ${ }^{100}$ Whether the ban on Muslim witnesses was considered a detail to be stipulated in the ferman s and other sultan's decrees complementing the treaties, or Venice and the Porte found it useful to leave the question open to discussion deserves further investigation. However, the very fact that the ban is repeatedly mentioned not only in in Polish and Tuscan treaties, but also in those with increasingly prominent partners such as the French and the English, makes all the more intriguing its absence in Ottoman-Venetian ahdnames. Venice was the Ottomans' most favored trading nation, and the missing clause certainly cannot be pinned on her diplomats' inexperience.

Be that as it may, the 1718 Ottoman-Venetian agreement explicitly mentions both the Carazari clause, and the probative value of documents, and this late treaty provides us with a more sophisticated version of documentary practices. The agreement states that for mixed deals contracts needed to be registered and the subsequent hüccet delivered to both parties; for potential claims, the judges were obliged to compare the contract itself with the hüccet and the notarial protocol - that is, the qadi's sicil. ${ }^{101}$ In the absence of any of these articles of proof, the judge should proceed by hearing righteous witnesses, taking special care to ensure their probity. The 1718 treaty makes it clear that contracts, presumably written, could be concluded outside of a court of law; for example, contracts involving one or two Muslim parties and signed before the Bailo's notary were not unknown. In March 1602 a certain Osman Re'is appointed Cussem Re'is as his attorney for a maritime business, and so did two janissaries in the following days, having these deeds notarized by the chancellor of Bailo Girolamo Cappello. ${ }^{102}$ However, when it came to the resolution of mixed conflicts, ideally contracts, a proper hüccet delivered on request to the parties, and the original record bound in the qadi's sicil had to be inspected,

\footnotetext{
100 Miltitz, Alexandre: Manuel des consuls, Londres \& Berlin: A. Asher, 1837-1841, II, 1489.

101 "ils devront faire enregistrer leurs contrats et recevoir le hodjet ou autre acte juridique; et s'il s'élève un différend, on devra comparer le contrat, le registre ou Protocole et le hodjet, et juger d'après la Conformité qui existera entre ces trois pièces; et lorsqu'on ne pourra produire aucune de ces trois pièces, et que l'équité exigera néanmoins que le différend soit jugé, les juges, en vertu de leurs pouvoirs judiciaires, devront accueillir les demandes en justice complètement et équitablement: ils devront peser, avec l'attention convenable, les témoignages ..., , ibid. II, 1489.

102 ASVe, Bailo a Costantinopoli, Atti e Sentenze. Protocolli 271/ 67v-68r, 4 March 16o2, 68v, 7 March 1602 .
} 
and only in cases in which none of these documents could be produced were witnesses summoned.

The obligation to register contracts before the qadi, and their capacity to overrule witness testimony has been signaled as a deviation from the spirit of sharīa or, for Timur Kuran, as a sign of the yielding of a sharīa-based legal system to the economic realities of the time-a process that would be completed in the nineteenth century. However, we should take into consideration the possibility that it was the rigid application of the witness system itself that caused this development. The compulsory nature of the hüccet might also have come about due to the very attitudes towards diversity adopted by the Ottomans. To be sure, apart from intra-communal matters, the hanafi school was particularly rigid in its refusal to accept dhimmīs as eligible witnesses; compared to under the Mamluks, we find no trace of bilingual simsārs, the Christian and Jewish scribes working for the customs, nor is there mention of the hạjibs' courts and their flexible approach to proof and procedure. Similarly, the Ottomans did away with the tendency to blur the boundaries between linguistic mediation and notarization, as was the case under the Mamluks. Dragomans were only recognized in their capacity to provide translation and interpreting services, and their presence was made compulsory in court, whereas it had not been deemed necessary in medieval times.

In the context that emerged in the early decades of the 16th century, actors discovered that legal disputes were necessarily heard by the religious learned, who had no sympathy for procedural deviations. As Giovanni Dario put it during discussions about the building of a bridge near Ulcinj in Montenegro, "we especially have to deal with bigots, and with people who observe the Holy Scriptures and who are not willing to be contradicted, notably the pashas who are religious learned men."103 Accordingly, in a given trial where the parties needed to prove their positions by means of testimonial evidence, the temptation to forge fake depositions was strong. As I claim in the section devoted to false witnesses, the danger was real enough to provoke a strong reaction from the Ottoman authorities against the proliferation of false witnesses, by publicly summoning and punishing a notorious liar in Istanbul. When a lawsuit revolved around two contradictory statements, by witnesses of different religions, judges were necessarily inclined to give the Muslim party precedence, or to be more precise, to the party defended by Muslim witnesses - a position epitomized by Ebu's-Su'ud's opinion on the village inhabited exclusively by

103 "et maxime habiando afar cum pizochari che e prima el Signor che man ti en la lege Santa che non vol aldir parola contraria. poi sono do Bassa che sono homeni de la fede," Dario, 22 dispacci, 220. 
infidels, where one Muslim murders a dhimmī, and where the Muslim cannot be found guilty on the basis of dhimmì testimony.

It is indeed possible that the supremacy of oral witnessing may have caused contracts exhibited by Franks be overturned by false witnesses, as was often the case in disputes involving Christian prisoners enslaved by Muslims. As an obvious solution for this problem, the ahdnames began to insist on the compulsory nature of hujjas, and to introduce explicit limitations to testimonial evidence. This may go some way to explaining a crucial question in the chronology: the ban on Muslim witnesses took a few decades to consolidatefor example in the realm of norms governing cross-confessional exchangeswhile the promiscuity between dhimmīs and mustämins in court- the Carazari clause- had been sponsored since 1500, if not earlier. Grignaschi showed that even jurists adopting a stricter approach to hanafi doctrine on matters of witnessing, such as Ebu's-Su'ud, ended up making similar concessions to the Ottomans, and eventually accepting dhimmī witnessing to prove issues related to the ownership of land. As we saw earlier, the maslaha had been invoked by medieval Arab jurists dealing with Siyāsa, and in the same manner in the Ottoman context many debates revolved around the notion of istihsān to allow judges to rely on dhimmì witnesses for specific cases. While it is tempting to interpret such changes as pragmatic steps towards a more secular version of the rule of law, in promoting such measures the Ottomans were more motivated by their own quest for orthodoxy, and by their desire to distinguish their own approach from previous Mamluk practice, and from the corruptness of the Mamluk 'udūl.

\subsection{Dhimmī Claims on Communal Exclusivity: the Carazari Clause}

Cross-confessional relations constituted an arena in which convoluted interactions played out between jurists' ideas, the Ottoman-sponsored version of these principles, and bottom-up reactions from legal actors. Although unbelievers could not be heard against Muslims, their testimony was accepted for cases involving other unbelievers. An area rife with contention, the hanafì exception began in those years to deviate into very peculiar ideas and practices about proof that, I argue here, have gone unnoticed and open new angles for understanding early Ottoman legal attitudes. For example, for more than a century local Christians and Jews brandished the hanafĩ exception so as to clearly distinguish between themselves and the mustämins in court. Dhimmīs claimed that they formed a legally separate community, and that therefore only the word of other Ottoman Christians and Jews could be used against 
them in court. Consequently, they would request the exclusion of Franks as witnesses against them, a measure that, if implemented, could compromise the resolution of disputes between these two prominent groups in Ottoman trade. These privileges were never fully embraced by the Ottoman government, but the idea that witnessing and proving claims should be associated with one's confessional group, rather than one's religion, permeated legally relations between the Ottomans and their neighbors. Probably from an early stage in the history of diplomatic agreements, and certainly since 1500, dhimmīs had been raising this specific point that, if successful, would have invalidated the word of Franks in mixed trials. Extant texts mentioning this request, such as the 1575 Ottoman-Venetian treaty quoted below, make it clear that in mixed cases dhimmīs wished for the opposing party to prove claims by means of local, dhimmī witnesses:

Che essendo la prima differentia tra quelli della natione venetiana et alcuni christiani carazari, et vegando li veneziani produceano testimoni della loro natione, onde li adversari, con dire bisogna testimoni christiani di questo loco, davano travagli alli detti, et non accettavano la testimonianza delli christiani veneziani. Pero per essere christiani tutti d'una fede ho commandato che se li veneziani haveranno differentia con li christiani, et che gli faccia bisogno produr testimonii, producendo christiani, siano di che nazione si voglia, posano testificar, et secondo l'honesta legge del profeta sia accettata la testimonianza loro. ${ }^{104}$

In the present work, I refer to this legal claim as the carazari clause. Carazari is a term that became popular in the context of Ottoman relations with the Franks; originally deriving from carazo (ar. kharāj), referring to the poll tax paid by the dhimmì population, Christian and Jewish Ottoman subjects came to be known as the carazari in commercial-diplomatic jargon. The carazari clause was often invoked by Jewish and Christian subjects of the Ottoman Empire, advanced in contexts of commercial litigation and in the drafting of ahdnames and agreements. The mainstream hanafi approach to the question, as epitomized in the Multaqā of Ibn al-Ḥalabī, tended to lend support to this claim raised by Ottoman dhimmīs. ${ }^{105}$

104 ASVe, Libri commemoriali, Registri, Reg. n. 24, chapter 26 of the 1575 Venetian-Ottoman Treaty. Published in Theunissen, Ottoman-Venetian Diplomatics, 530-46 ("carazari clause", 539), from a different source: ASVe, Documenti Turchi 828.

105 Heyd, Uriel and V. L. Ménage: Studies in old Ottoman criminal law, Oxford: Clarendon Press, 1973, 245. 
To the best of my knowledge, the first reference to the carazari clause can be found in the 1500 treaty with Florence. The text points an accusing finger at, in the first place, Jews, followed by "any other nation" except the Muslims. The setting for this early mention is, most probably, the intense trade Florentine merchants were conducting in Bursa and Constantinople.

Whenever Florentines have any difference with Jews or any other nation, except with Turks, the former often refuse to accept the testimony of Florentines. And I command that they should accept the witnessing by a Florentine against any nation, except against Muslims, and the qadi must sentence in their favor. ${ }^{106}$

As for the Turkish versions, early treaties render the carazari clause in full, as is the case for the agreement drafted by the Porte in 1502 and ratified by Venice in May 1503, followed by a subsequent renewal by Selim I in 1513. According to these treaties, in legal conflicts with non-Muslim tributaries, Venetian, unbeliever witnesses were to be admissible in court. The ${ }^{1502-1503}$ rendering is succinct, simply mentioning the validity of cross-confessional witnessing, while the 1513 version adds new discursive elements to the clause's formulation. Ottoman rulers claimed that, in this regard, they were following the example of the Prophet Muhammad and that all Christians were to be considered as a single nation (millet-i-vahıde). These elements would crystallize in later documents, as in that underwritten in 1575. In all probability, both arguments for and against cross-confessional witnessing centered around the hadìths related to the activities of Muhammad in Medina and his role delivering justice among the city's different communities. Whatever justifications they used, the sultans made their legal choices not by virtue of any arbitrary power, but by underlining their conformity with specific acts described in the Prophet's sunna. ${ }^{107}$

One would expect to encounter the carazari clause in all successive treaties after that of 1503 , however this is not necessarily the case; the FrenchCatalan treaty signed with Süleyman I in 1528, for example, does not mention

106 "Et havendo detti Fiorentini differentia con Giudei o con qualche altra natione, da' Turchi in fuora, piu volte non vogliono acceptar testimoni fiorentini. Et io ho comandato che contro ogni natione, eccetto Turchi, debbino acceptar testimonianza di detti Fiorentini, et il Cadi debbe sententiare in favor di essi." Camerani, "Contributo alla storia dei trattati commerciali fra la Toscana e i Turchi", 94.

107 De Groot, "The Historical Development of the Capitulatory Regime", 591, Theunissen, Ottoman-Venetian Diplomatics, for the treaty of 1503,386 , art. 35 . For that of 1513 , 398, arts. $41,42,43$. 
the carazari clause. ${ }^{108}$ The text is considered to be a renewal of the Mamluk privileges enjoyed under Sultan Qānșūh al-Ghawrī, which is probably the reason why the issue is not mentioned. As we can observe in late Mamluk treaties with the Italian cities, the Mamluk chancery was not concerned with the problem, and in fact it is absent from late agreements such as that granted to Florence in 1489, although issues of adjudication and procedure are dealt with at great length. ${ }^{109}$ The 1528 text refers to the conditions necessary for the conclusion of deals, making it clear that traditional patterns of notarization were still in use. Even though the dhimmīs are not mentioned, the text raises the issue of witnessing amidst diversity. In the first instance, a murky passage in the French translation refers to the fact that Muslims have full witnessing capacity, particularly in cross-confessional disputes, while Franks do not. Secondly, the text depicts a situation where business deals could apparently still be concluded without the presence of witnesses, but in the event that witnesses were summoned, Franks could only bear witness on behalf of their coreligionists. ${ }^{110}$

Unlike the French treaties, the Venetian ones invoke the carazari clause starting with those issued in 1503, 1517 and 1575 , and up to the eighteenth century. ${ }^{111}$ In 1575, explicit mention was made of the idea that Frankish witnesses should be admissible for or against dhimmīs, because all Christians practice the same religion, and that differences in residence should not be used as an argument against their capacity to testify. ${ }^{112}$ Sixty years after the 1513 forerunner, the ahdname evokes the language used by the religious learned in legal reasoning, mentioning the example of the Prophet Muhammad, or the Ottoman-sponsored idea that dhimmīs and mustā'mins belonged to the same $d \bar{a} r$. It is clear at this point that ahdnames issued to the Venetians were addressing a particular concern encoded in the legal debate, and for this purpose echoed the language used by hanafì authors such as al-'Aynī a few decades previously. In contrast, Ottoman ulama such as Ebu's-Su'ud were equally aware of

108 Charrière, Négociations de la France dans le Levant, 121-9.

109 Wansbrough: "A Mamluk Commercial Treaty", such as clause XX and XXVI for adjudication and XXVII for notarization.

110 "S'il se conclurra marché en la présence de tesmoins, que les tesmoins soyent escritz le Franc avec le Franc, comme il s'escrit, et le More avec le More et avec le Franc, et s'ilz voudront que les tesmoins se soubzcrivent, qu'ilz ne le pujssent refuser et ne leur soit empêché comme aussi de la police de recevoir." Saint-Priest and Schefer, Mémoires sur l'ambassade de France en Turquie et sur le commerce des Français dans le Levant, 350, Charrière, Négociations de la France dans le Levant, 124, 128.

111 Theunissen, Ottoman-Venetian Diplomatics, 392, 539, 411.

112 Ibid., ch. XXVI, 539., Miltitz, Manuel des consuls, II, 1486. 
the ruler's approach to witnessing and unbelief, and expressed disapproval for the "traditional mistakes" conveyed by the treaties. ${ }^{113}$

One could ask: if priority is given to historical context over legal theory, was the ban on Muslim witnesses invoked at all times, and for all the trading nations? Although an unequivocal answer to this question would require a more thorough scrutiny of Ottoman diplomatic production, a preliminary comparison of treaties between different nations does demonstrate that the dhimmì biases against Frankish witnesses were particularly intense in the case of the Italians. Ottoman-Polish treaties began invoking the need to notarize by means of hüccet and sicillat in 1553, and then reiterated the compulsory nature of this measure in 1564, 1557, 1591, 1597, and 1598. Incidentally, these treaties only implicitly mention the ban on Muslim witnesses, as they argue that in the absence of valid documents witnesses will be heard, putting a strong emphasis on the need to rely on honorable ones. No mention is made however of the carazari clause in 16th-century Polish treaties, which can only mean that the merchants from the Italian nations, and first and foremost the Venetians, were much more prone to litigate in court than their Polish counterparts, addressed in these agreements. After all, in the negotiations for the 1575 agreement, it was the Venetians themselves who included the argument in the diplomatic agenda, which later crystalized in the ahdname. In other words, the specific nature of Veneto-Ottoman relations differed from relations with other powers, since they went far beyond the quest for legal security and commercial privileges. Such relations implied delicate diplomatic exchanges, in which not only specific claims, but Islamic legal doctrines and positions were invoked by all actors, and opened the arena of negotiation to include just as equally the Porte, the Doge, the Ottoman tax-paying subjects, and Frankish merchants. The carazari claimed that local and foreign Christians belonged to different sects, and that their testimony naturally tended to be biased against one another. Jurists such as Ebu's-Su'ud adhered to hanafì doctrine in that he insisted that dhimmì witnessing should be accepted across confessions, but that this should not include the Franks. The Ottomans ran counter to this, repeatedly asserted that it was "the Law of the Prophet" that conveyed the idea of a single community of unbelievers, and that this community included Frankish merchants, hence deviating from the mainstream hanafì interpretation and distancing themselves from their own flagship jurist.

113 “Non. Le temoignage des « musta'man » contre les « dhimmi» n'est guère admis par aucune des écoles juridiques. Dans les traités qui ont été accordés aux « musta’man », il y a des erreurs traditionnelles. On ne leur donnera pas exécution." Grignaschi: "témoignage des sujets non musulmans", 255 . 
Several remarks can be made at this juncture. Venetian diplomacy was early to underline the importance of the carazari clause, however it would take her over two hundred years to claim the right for their subjects to refuse Muslim witnesses in the absence of written documents. The carazari clause seems to have predated rulings on the compulsory nature of notarization, or at least was prioritized in the drafting of treaties. Moreover, it was entirely absent from treaties with a priori minor nations such as Poland.

The absence of the ban on Muslim witnesses in Venetian-Ottoman ahdnames suggests that Ottoman action was more concerned with governing amidst diversity, than with the opportunistic granting of privileges to meet economic imperatives. It also speaks of the political nature of Venice's relationship with the Ottoman Empire. Venice refrained from requesting a privilege known to all and sundry - the ban on Muslim witnesses - that would have put her subjects in the same position as those of inexperienced nations. Unlike Venice, latecomers lacked sufficient resources to prevent conflicts with local dhimmiss, and they could not deter the actions of cheating plaintiffs. By this, I am not implying that Venetian merchants simply renounced commonlyaccepted procedural advantages; indeed, when necessary they actually brandished the decrees relative to their rights. However, it is clear that as a nation marked by an unrestrained proximity with the dhimmī community-with many of its members even enjoying ambiguous statuses - the Venetians were eager to avoid having cases thrown out on procedural grounds. Similarly, I conjecture, we should not exclude the possibility that the Ottomans refrained from granting exceptional privileges to a nation whose members often had poorlydefined statuses, and many of whom appeared in poll-tax registers.

Issues constantly arose due to the Venetians' closeness with the carazari community, and their contested statuses often came to the fore when the estates of ambiguous subjects were at stake. For example, a certain Piero Ginardi, "our Venetian ... passed himself off as a dhimmī (carazaro) for his businesses with Bursa, since he figured in the poll-tax books, although under a not so clear name," noted the Bailo, before describing his efforts to reclaim Ginardi's estate. ${ }^{114}$ Eric Dursteler has devoted a long section in his 2006 study to

114 "Piero Ginardi nostro veneziano, si spazzava per carazaro nelle facende che facea per bursa, ... et era notato sopra li libri delli carazi, se bene con uno nome non tanto chiaro, subito, che fu morto, andorono li beltramaggi che sono come li cattaveri di vostra serenita et bollorono tutte le robbe sue in casa, et nelli magazeni. Perche di tutti li carazari che muoreno in queste parti senza haver testato alla turchesca, et senza figlioli, è herede questo serenissimo signor, ho trovato una fattica estrema, et anco con qualche spesa, non già di vostra serenita per far liberar dette robbe, sopra le quali ho fatto metter il sigillo per 
a description of the many Venetians in Constantinople of ambiguous status, and which included a large group of exiles. ${ }^{115}$ Under these circumstances, indulging in legal definitions was deemed less useful than handling claims as they came in the daily practice of courts. Since nothing of the like was ever at stake in Mamluk times, these two issues can be described as characteristic of the Ottoman agenda in the field of cross-confessional relations. However, they can also tell us something about the Ottomans' priorities and methods; although contested, the two anomalies mentioned above referred to sharía as justification, and were expressed by the lawgiver in the language of the jurists. Combined together, this piecemeal innovation in amān treaties underlines the priority given to the hanafì qadi in the daily life of mixed relations, and sets a line of demarcation between the thriving dhimmì community and their Muslim social superiors, rather than between dhimmīs and the undisciplined mustä'min community. Closing the circle of enforcement, Muslims, by virtue of the ban on Muslim witnesses against Franks, were reminded not to abuse the legal superiority granted them by sharīa. Such a warning was all the more relevant in light of the perilous proliferation of false witnessing.

\subsection{False Witnessing}

Just as reliance on written documents favored the circulation of forgeries, the Ottoman position on testimonial evidence fostered the action of false witnesses. The criminal code of Süleyman the Magnificent devotes special attention to the forgery of witnessing and hujjas, together with official decrees (hukms). ${ }^{116}$ In my research, I have not come across any references to the issue in Mamluk commercial litigation, nor does the recourse to false witnesses seem to have concerned diplomatic negotiators. ${ }^{117}$ Under Ottoman rule, however, complaints had become frequent by the 1530s. "The fact that justice depends on the witnesses' depositions leads to much abuse in Turkey, since by means of money there will always be witnesses for whoever needs one," Bailo Gianfrancesco

la man cancellaria," ASVe, Senato, Dispacci degli ambasciatori e residenti, Costantinopoli, $1 \mathrm{~A}, 326-8$.

115 Dursteler, Eric: Venetians in Constantinople: nation, identity, and coexistence in the early modern Mediterranean, Baltimore: Johns Hopkins University Press, 2006, 61-103.

116 Heyd and Ménage, Studies in old Ottoman criminal law, 121.

117 In Ambasciata straordinaria al sultano d'Egitto (1489-149o), Franco Rossi has edited the only extant, complete documentary trove pertaining to a Venetian embassy to the Mamluks. Justice and procedural issues were never mentioned in the diplomatic agenda. 
Morosini wrote in his relazione. ${ }^{118}$ According to Giovanni Moro, writing in the 1580 s, if the Turks relied on witnesses, it was due to the summary handling of justice and their disregard for documents, which "are only valid if corroborated by witnesses." For these reasons "witnesses abound, who for a little money can confirm whatever the parties wish."119

False witnesses came in handy when proper documentation of deals was absent. In parallel to the proliferation of false witnesses, it soon became customary to forbid, in mixed cases, the issuing of verdicts based on the depositions of forged testimonies alone, without any supporting documentation. This tautological clause found its way into the drafting of ahdnames, and is mentioned, for example, in the six treaties signed with Poland throughout the sixteenth century. The problem was brought up by French diplomats in 1540 and 1569: when deals turned bad, false witnesses showed up in support of forged accusations of insults to Ottoman subjects. ${ }^{120}$ French merchants, the diplomats complain, fall bankrupt, and in order to recover their losses, Muslim merchants sue other Frenchmen. For this purpose, Muslim witnesses are forged, hence the necessity to notarize.

Bien souvent, il arrive que quelques marchands François font banqueroute de grandes sommes aux sujects du Grand Seigneur, qui pour se récompenser de telles pertes, s'en prennent aux autres marchands de la nation, et leur veulent faire payer leur perte, comme s'ils estoient obligez de ce faire, se servants, pour c'est effet, de faux tesmoins. Pour à quoy remédier, il est dit en l'article trente quatre, que s'il n'apparoist que ces marchands ainsi poursuivis, soient cautions par contracts authentiques, qu'ils ne soient molestez, ny tenus des debtes des fuïards. ${ }^{121}$

118 'Il far dipendere la giustizia dal detto de' testimoni causa le molte avanie che si usano in Turchia, perché con denari mai mancano testimoni falsi a chi ne avere. E per concludere, tutta questa giustizia, cosi civile come criminale, si può chiamar grandissima ingiustizia, poiché ella depende da testimoni che si comprano, e viene fatta da giudici che per il più la vendono," Relazioni degli ambasciatori veneti al Senato, Serie III, Volume III, 273.

119 "Attendono i giudici alla brevità e, tralasciando i lunghi sermoni d'avvocati, risolvono prestamente le cause con poca lettura di scritture, molto diversamente dall'uso degli altri paesi, quando non siano comprobate col detto di testimonj; dei quali là più che altrove ne abbondano de' falsi che con poco danaro confermano quello che è desiderio della parte," ibid., 376 .

120 Saint-Priest and Schefer, Mémoires sur l'ambassade de France en Turquie et sur le commerce des Français dans le Levant, 370-1, 388 (1581), 407 (treaty of 1597). For the treaty of 1569 , BNF, DO, Ms. Turc 130, f.4r.

121 Saint-Priest and Schefer, Mémoires sur l'ambassade de France en Turquie et sur le commerce des Français dans le Levant, 427. 
French consuls seem to have been deeply concerned by this issue. Numerous times, they insisted on the tendency to charge foreign subjects by means of false witnesses, which could even include serious accusations such as blasphemy, hence psychologically blackmailing judges on religious grounds. ${ }^{122}$ Unlike the French, the Venetians do not seem to have included this issue in the letter of their treaties, although Venetian representatives were well aware of the problem in their daily activities. The consul in Egypt complained of being wrongly prosecuted by a Sanjakbey, who had fooled the qadi of Alexandria by advancing false witnesses. ${ }^{123}$ So too did Giovanni Dario stumble upon a Greek renegade who, allegedly, bore false witness in an important smuggling affair. After his version was dismantled by the ambassador, the Greek witness was delivered to the executioner. ${ }^{124}$

The Abdellatif affair was a highly disputed case that took place in the mid1550s, and epitomizes the threat posed by false witnessing to cross-confessional relations in general. Abdellatif's alleged fraud, like in the novel by Carlo Emilio Gadda, acquired the contours of an "awful mess," reaching far across the Ottoman territories and involving several courts and consulates. The affair was triggered when, after the seizure of his cargo by the Venetians of Cyprus, Abdellatif brought a complaint before the qadi in Cairo. Although we do not know the grounds for this decision, the case was transferred to the Syrian courts. Eventually, the Venetian Bailo had wind of it, who brought the dispute to the attention of the imperial Dīān in Istanbul. In gross, Abdellatif requested that the Cairo consul be held liable for his losses. Allegedly, he had in his possession a declaration by the consul in which the latter admitted his responsibility for the seizure of the cargo and committed to reimburse the Muslim. Armed with these hujjas, he moved to Tripoli where similar commitments were obtained, backed by the local qadi. Abdellatif eventually showed up before the beylerbey in Aleppo in 1555. The latter's intervention led to the detention of the Venetian consul in Aleppo, forcing resident Venetians to urgently dispatch a messenger to Istanbul. At this point, the Abdellatif affair had acquired cumbersome

\footnotetext{
122 'Qu'estant dressé quelque embusche contre les François pour les accuser d'avoir injurié et blasphémé contre nostre Sainte Religion et produisant des tesmoings faux pour trouver moien de les travailler," Ibid., 407.

123 ASVe, Senato, Dispacci Consoli, Egitto B1, 33, f.2, "avendo detto sanzacco voluto con falsi testimoni dare ad intendere che'l fu battalado ingiustamente, con haver fin contentado il cadi vecchio d'Alessandria perchè dicesse ben di lui".

124 "poi comenci a parlar io et breuemente et saldamente ho reprouado tuto quello che haueuaho ditto: per modo che li Bassa intexe le justificacion mie fulmirono contra de luj et contra quel rebaldo Schiauo che haueua fato false relacion ala porta per guadagnar questi dinari. et subito lo feceno metere in man di boia," Dario, 22 dispacci, 212.
} 
proportions, and the bailo hastened to the imperial Divañn to demand the beylerbey's head. The legal arguments on Abdellatif's side resided in the hujjas he had presented as proof, whereby the consul (it is unclear to what extent the consul in Cairo was also involved) accepted his own liability. The consuls denied the very existence of these records, and refused to pay, on the grounds that well-known clauses in the treaties protected representatives from being held liable for their subjects' losses. The consul in Aleppo cited this argument in his refusal to produce witnesses in his favor, since such a decision would have been "prejudicial to the capitulations." Upon this, the beylerbey was summoned to Istanbul, where he exhibited a memorandum drawn up by the qadi in Aleppo, in which the latter acknowledged the validity of the hujjas incriminating the consul. ${ }^{125}$ The bailo's secretaries examined the records and concluded that they had not been effectively notarized, and that it was not logical that the consul would have chosen to become involved in this affair.

Probably due to the involvement of officials, for whom alternative forums were envisioned, the dispute was brought before the kadiasker, the competent high authority empowered to judge the military class. However, the Venetians refused the kadiasker as the competent court, and maneuvered to have the dispute placed in the hands of the pashas at the Divaān. ${ }^{126}$ For the bailo, Abdellatif had followed different legal strategies in Cairo and in Istanbul, most notably by playing out evidence that had been produced elsewhere. As we have seen in the Chapter Two, medieval jurisprudence tended to severely curtail the transfer of probative artifacts from one court to another, whilst, as shown by Reem Meshal, under the Ottomans even copies of hujjas began travelling with their right-holders across the Empire. In the end, aside from his cargo, Abdellatif managed to recover the loss of one of his slaves, who had escaped in Cyprus and been forced to convert to Christianity — a highly sensitive issue at the Dìvān. ${ }^{127}$ For the bailo, Abdellatif had been unable to find his slave through legal channels, so he had deemed it more useful to return to Egypt and procure himself forged evidence to back his claims, and then sue the Venetians in Syria with the help of these documents. The bailo narrates a previous episode in

125 "Il quale dapoi aver detto quanto gli parve sopra cio, presento un'arz dal cadi di Aleppo, per il qual pare, che quel cadi faccia fede, che sara provato per sigilletto che dal magnifico consolo sia stata fatta la sopradetta promissione al turco.", ASVe, Senato, Dispacci degli ambasciatori e residenti, Costantinopoli B. 1A, 228c.

126 "che dimane devessero ritornare avanti li cadilaschieri, alquale fu risposto per essi secretari, che le cose di vostra serenità non haveano daesser giudicate, se non dal Serenissimo Signor., ASVe, Senato, Dispacci degli ambasciatori e residenti, Costantinopoli, B. 1A, 228c.

127 ASVe, Senato, Dispacci degli ambasciatori e residenti, Costantinopoli, B. 1A, 394. 
1550, when a Christian slave of his had successfully sued Abdellatif, arguing that the latter had experience manipulating the judges, fabricating evidence and abusing religious pretexts in court. More importantly for our argument, Abdellatif frequented Christian chanceries such as that of the bailo in Constantinople, where contracts were registered by the consular notary. In the bailo's narrative, after having contracts drawn up by Latin notaries, when needed Abdellatif was prone to contest such transactions before Islamic judges with the help of false witnesses.

It is worth noting here an interesting point regarding both parties' performances in court. Abdellatif adopted dilatory tactics, often failing to show up at the Dīvann. The consulate, on the other hand, put the story into writing and had this read by the pashas. The pasha then learned that the Cypriot magistrates "had proceeded to open an inquiry, and have passed a verdict in the Christian way." In his self-congratulatory narrative, the bailo took up cudgels for Venice's justice: "and I answered him that justice is universal, and that irrespective of the place it is done, it is always fairly done, and most particularly that emanating from Your Most Serene Grace ... he then roared with laughter, and said 'write to the doge that I have ascertained the validity of the deed, and will issue an arz for the Sultan.' "128

Antonio Barbarigo suspected that not only Abdellatif, but probably also the pashas had an interest in protracting the dispute indefinitely. By that time the word divān, which before had been used uniquely to talk about the ceremony of diplomatic and legal exchange, had taken on a temporal meaning, with expressions such as "during these last dīvāns," etc. In that period too, the bailo attended some sessions and paid private visits to the pashas, but for minor hearings relied on a team of secretaries directed by a most experienced dragoman called Giannesino. Abdellatif, who seemed to be monitoring his opponents' appearances in court, showed up unexpectedly at the Dīvān at one of these sessions, in a calculated performance by means of which he obtained the transfer of his lawsuit from the pasha to the kadiaskers. As had happened months earlier, this transfer was deemed prejudicial to Venetian interests, and Barbarigo and his secretary labored to bring Abdellatif to court, with

128 "la ho veduta, quelli giudici di cipro hanno fatto teftis, et giustitia alla cristianesca, ond'io rispondendogli che la giustitia al mondo era una sola, et pero' in ogni parte quando era fatta essa giustitia era sempre bona, et giustamente fatta, et in particolare da vostra serenità, et sui rapatante, ella si mise a ridere, et disse scrivete alla Signoria ch'io ho accertata la scrittura, et che ne faro' arz al gran Signor, ne manchero' di aver questa cosa à cuore, come lei desidera, la ringratiai.", ASVe, Senato, Dispacci degli ambasciatori e residenti, B. ıA, f. $400-402$. 
the intention of having the Venetian plea read in his presence. By so doing, they expected to force an acknowledgement from the plaintiff's side. Again, the kadiaskers admitted they were granting Abdellatif a further opportunity to substantiate his claims by means of qadi-produced evidence. The Muslim merchant was indeed laboring to obtain a favorable sentence from a qadi in Istanbul, a decision the kadiaskers intended to examine before transferring the case again to the pashas. ${ }^{129}$

As we saw from the Venetians' point of view, the Ottoman version of the witness system, as well as their increasing reliance on qadi-registered instruments, was becoming an obstacle to mixed justice. According to the bailos, fraud could be committed by qadis acting as notaries, and, as we shall see, claims from captives who had been forced to subscribe false debt contracts before the qadis were often reported. ${ }^{130}$ Although post-conquest reform sought to do away with traditional notary-witnesses drafting deeds from their stalls, the new praxis ended up favoring the presentation of serial witnesses at hearings, among whom hid serial false witnesses. Neither did the new procedure prevent the action of ill-meaning cadis, such as those allegedly operating for Abdellatif's cause. Hence the bitterness of Ibn Nujaym, who pointed out that in the case of unbelievers, children, and witnesses afflicted by temporary loss of hearing, in some cases (not against Muslims), whenever these limitations were overcome, their testimony was accepted. Although repentance was accepted in a person who had once given false testimony, it was not accepted in the case of the professional notary-witnesses. ${ }^{131}$

A story confirming the proliferation of false witnesses is reported in July 1547 in the following terms. Zuan Burletto of Chios, probably a tax farmer for the Ottomans, wished to reclaim money from a certain Venetian called Francesco Michiel. Michiel was a merchant in Constantinople where he represented the interests, among others, of a certain Zaccaria Morosini. Both men belonged, in all probability, to the Venetian ruling elite, the nobility. Morosini was indebted to Burletto for a much larger sum, of at least 23,00o ducats. In all probability, Burletto, with the help of false witnesses, expected to recover part of his sizeable credit not directly from Morosini but from Michiel, his commercial agent in Istanbul. Burletto had his own motivations, as he owed

\footnotetext{
129 ASVe, Senato, Dispacci degli ambasciatori e residenti, Costantinopoli, B. 1A, 40o-2, 431.

130 ASVe, Senato, Dispacci degli ambasciatori e residenti, Costantinopoli, B. 1A, 429, mentions a friar forced to sign 'a sijill' committing to ransom Muslim captives, ASVe Senato, Dispacci Consoli, Egitto B1, 42, describes how captives who may have been the object of Frankish interest were forced to sign bills of exchange and obligations.

131 Ibn Nujaym, al-Ashbāh wa-al-nazā̄ir 'alá madhhab Abì Hanīfah al-Nu'mān, 270, 275.
} 
three thousand ducats himself to the hazine, or Imperial Treasury, and for this reason he counted on the support of some secretaries ("the defterdars") in his plot against Michiel. Endorsed with the hazine's support, Burletto managed to have the judicial officers (chiaus) sent after Michiel and have him brought before the defterdar. Since the case involved a protected mustä'min, this official had the trial transferred to the Dīvān, where the bailo took charge of Michiel's defense in several hearings. At the Imperial Council, the bailo encountered the kadiasker, who was sitting in justice, and both parties were heard. The bailo stuck to the argument that Burletto was targeting Michiel on behalf of Zaccaria Morosini, hence violating the principle of individual responsibility stipulated in the treaties. In addition, the bailo cited an executive order by the sultan (commandamento, most probably a ferman) affirming that in cases over five thousand aspre, witnesses should not be heard in the absence of written documents, properly notarized by the qadi and incorporated in the court's sicil. 132 Incidentally, this confirms that the Venetians made use of the ban on Muslim witnesses without having it explicitly mentioned in the treaties. Yet in spite of the bailo's sound defense, the kadıasker decided to hear Burletto's witnesses. At this point, the reader readies himself to encounter the usual narrative of bitter grievances about unfair Muslim justice. Instead, the bailo reports to the Doge what constituted a conscious and calculated Ottoman reaction, not only to Burletto's plot, but to the larger threat posed by false witnessing in the conduct of cross-confessional justice. The kadıasker, the bailo argues, was planning, with the help of Ottoman officials, to have Burletto and his witnesses punished. If we are to believe the bailo, some Muslims in Istanbul were making a living out of bearing false testimony, and that Burletto's witnesses were false was known to all and sundry. The vizier Rüstem Pasha had them arrested and ordered the usual penalty inflicted upon corrupt judges and witnesses; they were paraded on the backs of donkeys for three days throughout the streets of Istanbul, bearing a cow's intestine around their necks, after which Burletto's witnesses were put to the oar in the galleys. Ibn al-Himșī describes the fall of a mālikĩ qadi in Mamluk Damascus a few years previously, to whom the same treatment was delivered, and we have mentioned similar descriptions by Ibn Fahd for Mecca. ${ }^{133}$

132 "uno commandamento del serenissimo gran Signor che vuole che testimoni delle cause da @ 50oo in su non siano admessi, ne ascoltati, se non vi è scritto in sigilleto del cadi. Non di meno parse al predicto magnifico Caddilaschier di voler admetter, et esaminar doi testimoni produtti per il predicto Burletto," ASVe Archivi Propri Constantinopoli, 1, fasc. IV, f.181-2, 17 July 1547 .

133 Ibn al-Ḥimṣī, Aḥmad Ibn Muḥammad (1473-1527 or 8): Hawādith al-zamān wa-wafayāt al-shuyūkh wa-al-aqrān, edited by 'Abd al-'Aziz Fayyad Harfush. Vol. 1-3, Beyrouth: Dār 
As for Burletto, the dispatch from the bailo adds that he was threatened with being bollato or sigillato, meaning "marked by the iron in three different places", in addition to being sentenced to the oar. ${ }^{134}$ Burletto was more frightened by the mark than by the gallows. Brought before the pasha at the Dìvān, he converted to Islam, hoping to exploit his new religious status to avoid "such a shameful marking". ${ }^{135}$ However, he still remained under some kind of judiciary detainment (he was still put in the hands of the chiaus). The bailo went to the Dìvān to congratulate the authorities "for this good justice", which would serve as a reminder to the "many false witnesses" who earned a living in this manner. Such "demonstration against false witnesses" had not been seen, the bailo added, in the last twenty years. Nevertheless, the episode did cost Michiel a good deal of money, as the pasha made it known that he desired a gift for freeing Michiel from the plot. The gift, considered to be part of the community's contribution to 'protection costs' was charged to the consulate, and the consulate's ruling "council of twelve" recommended Michiel spend "as little as possible" on it.

The Burletto episode described above is a reminder of the existence of executive decrees accompanying and complementing the ahdnames. A practice that was already in place in Mamluk-Venetian diplomacy, it was not confined to the labor of contingent embassies, but characterized by an open, uninterrupted diplomatic dialogue, with chanceries constantly issuing documents with amendments and updates. Ambassador Marco Minio reported, for example, a delicate decision concerning captives that the Ottomans had excluded from the formal treaty, but accepted instead to draw up in a separate decree. ${ }^{136}$ In Burletto's case, it was one of these documents that set the threshold for accepting witness testimony without documentary evidence at five thousand aspre. This means that adjudication was affected by two thresholds; one setting a minimum sum under contest for a case to be considered for a Dìvān hearing, and another setting a minimum amount before a judge should consider inhibiting standard shari`a procedure on the hearing of witnesses.

al-Nafā’is, 1996 261. Mu'ammar, "al-maghāriba wa manșab qāḍ̄ al-quḍ̣at al-mālikī fī dimashq al-mamlūkiyya”, 159, Ibn Fahd, Nayl al-Muná bi-Dhayl Bulūgh al-Qurá, 308-10.

134 De Villalón, Cristóbal: Viaje de Turquía, 213.

135 ASVe Archivi Propri Constantinopoli, 1, fasc. IV, f.182, "per fuggire questa vituperosa sigillatura, senza altra difficultà si fece musulmano".

${ }_{13} 6$ "lo volea etiam che fosse posto in detti capitoli che li schiavi, quali si avessero francato per qualunque modo si voglia, si potessero partir senza alcuna spesa né impedimento; questo non hanno voluto poner nelli capitoli, ma mi hanno ben dato un comandamento della detta contenenzia," Relazioni degli ambasciatori veneti al Senato, Serie III, Volume III, 89. 
Another interesting aspect of the Burletto case is the role played by the kadiaskers at the Imperial Council; permanent members of the Dīvān, their presence was - according to some authors-provided for when lawsuits were too numerous to be handled by the pashas alone. ${ }^{137}$ Two important diplomatic affairs that were transferred from the pashas' hands to the kadiaskers, were also sensitive issues from a religious standpoint. The 'Tirabosco affair' involved the debts left by Venetians who had either become Ottoman tributaries (carazari) or married dhimmī women. ${ }^{138} \mathrm{~A}$ vague, yet important article in diplomatic treaties dealt with this specific status, for which the Ottomans made an exception to the principle of individual responsibility. They also considered the consuls liable for the debts of Venetians who, having become official residents, had fled to their homeland. Bailo Domenico Trevisan warns the doge that in such cases, if Venetian merchants of carazari status died, their estates would be lost, since they would go either to their dhimmī sons or to the Bayt al-Māl. ${ }^{139}$ This was a delicate issue involving legal notions of amān and Islamic laws of obligation, and a certain Ahmet Pasha labored to have it transferred to the kadıasker. ${ }^{140}$ Lastly, the Venetians managed to unblock Dīvān negotiations by obtaining from a kadiasker the abrogation of an executive order blocking a ship. ${ }^{141}$

137 Heyd and Ménage, Studies in old Ottoman criminal law, 225, Atçil, Procedure in the Ottoman court and the duties of kadis, M. A. Thesis, Bilkent University, 75 .

${ }_{13} 8$ "Nella causa del tirabosco, et in alcune altre occorse al tempo di q. magnifico Acmat bassà, non le havendo posute finire con sua magnificentia volendo ella andar molto riservata si come le ho scritto altre fíate, fui forzato mandare il secretario et zanesino al divano, li quali sebene furono rimessi alli caddi leschieri, che cosi sono qui giudici di giustitia come sono in quella sudita citta li giudici delle corti ordinarie di vostra Serenità", ASVe, Senato, Dispacci degli ambasciatori e residenti, Costantinopoli, B. 1A, f. 184-5.

139 "Di questi mercadanti, alcuni nel tempo della guerra passata, per fuggire il pericolo della prigione, e per salvar la roba, si sono fatti carazzari di volontà, oltre quelli che avendo moglie e figli sono fatti carazzari per legge; dal che avviene che occorrendo la morte di quelli, sarebbe pericolo che fosse per seguire che il bailo di vostra serenità avesse travaglio, massime se quel tale restasse debitore di Turchi, e che li maestri che avessero mandate le faccende fossero quasi certi di perder tutto il lor capitale, perchè li figliuoli, se ve ne fossero, ovvero li deputati sui beni dei morti senza eredi, leveriano il tutto dalle man di quelli, e volendo li maestri ricuperare il loro sarebbero sforzati richiederlo alla giustizia, con le leggi e testimonianze a modo loro," Relazioni degli ambasciatori veneti al Senato, Serie III, Volume I, edited by E. Albèri, Florence: Società Editrice Fiorentina, 1840, 185-6.

140 "Ben le diro riverentemente, che succederano molte fiate di necesita delle dimande simili a questa contra il tirabosco, fino cheli sudditi sui, che vengono in queste parti, si fanno carazari di questo serenissimo signore overo si maritano qui, perche se quelli venirano in quella città, restando debitori de qui, saranno dimandati alla serenità vostra secondo li capitoli, et se li maritati lassarano figlioli sarà dimandato il conto della robba sua," ASVe, Senato, Dispacci degli ambasciatori e residenti, Costantinopoli, B. 1A, 184-5.

141 ASVe Senato, Dispacci Ambasciatori e Residenti, Constantinopoli. B. 1A, 374-6. 
The Antonio Priuli affair, not to be mistaken with the Marco Priuli bankruptcy discussed at the end of this chapter, concerned instead Muslim creditors against Venetian debtors. ${ }^{142}$ Himself the victim of unpaid debts of other Venetians, Antonio Priuli ended up owing 42.0oo ducats to the treasury. Pursuant to the huge debts incurred by Priuli and his associates, a bitter quarrel arose at the Divān on whether a certain Jew could stand surety for Priuli, and to what extent the Venetian consul could vouch for his own merchants. During the discussions, the kadıaskers provided the parties with legal advice, "based on their law'. The Jew, Salomon Alaschar, was not eligible as guarantor, since he was himself debtor to the treasury, hence the Ottoman interest in obtaining a guarantee from the Venetian consul in Cairo, Zuan Battista Querini. Some of these principles irritated the Venetian consul; he was requested to certify that at least some of the Venetian subjects concerned were both trustworthy men and merchants. The first, Querini argued, was an attempt to use this legal certificate as a personal commitment as guarantor. As for their being merchants, and unwilling to commit to signing any paper, the consul argued that it sufficed to check the customs registers, but he was answered that those records were kept by Jews, and therefore they could not be considered as proof (che sono libri de ebrei, et che non hano credencia)..$^{143}$ Needless to say, this clashed with Querini's notions of official documents: "this is absurd, since if someone is recorded as debtor in the customs books he is a debtor of the king." ${ }^{144}$ An Ottoman official, "a man of sharp intelligence" was looking for a loophole in the Venetian law of agency to force Querini to accept his own liability, using persuasion, some threats, and forcing the consul to fall in contradiction. In this, he eventually succeeded; since he could not commit to a pledge for his own subjects, the pashas drafted a list of five Venetians standing surety for the debtors, including some of the debtors' associates. Querini was required to approve the list of

142 ASVe, Senato, Dispacci degli ambasciatori e residenti, Costantinopoli, B. 1A, 258-6o.

143 Horii, Yutaka, "Venetians in Alexandria in the First Half of the Sixteenth Century", AJAMES 202 (2005), 131-144, 137-8. Reimer, Michael J., "Ottoman Alexandria: The Paradox of Decline and the Reconfiguration of Power in Eighteenth-Century Arab Provinces", Journal of the Economic and Social History of the Orient 372 (1994), 107-146.

144 "Io confesso a vostra serenita che se fuse novo in turchia fácilmente per questa fiata mi hariano ingannato, ma habisi questo per fermo et constante che in materia de piezarie quando uno aproba il piezo esser homo da bene tanto bien dito quanto chel sii sicuro, et de qui nase che loro (per sue leze) poi tanta accione hano verso colui che ha fato tal depositione, quanto verso colui che ha fata la piezaria, ala ragione de libri de doana mi bien dito che sono libri de ebrei, et che non hano credencia, questo e uno absurdo a considerarlo non che a dirlo, pero che se uno si trova debitor in diti libri e tenuto debitor del re senza alcuna contradicione et se dubitamo che diti libri da se non sino certi facino che il cadi laschiero faci la legalita," ASVe Senato, Dispacci Consoli, Egitto B1, 12. 
guarantors, something the consul "was unable to decline". The kadıasker immediately notarized a warranty deed with his personal sign (sigiletto) on it. ${ }^{145}$

If discrimination derived from formal sharīa principles, Frankish biases against scriptuaries were not better understood by Muslims. In 1557 a Pasha had commissioned to a Jewish Woman named (probably Gracia) Mendes, a piece of silken cloth. The item had been seized in Venice, Barbarigo argued, probably because it was not made clear that to whom it was directed, but that in any case she would not have been believed, since "truth is rarely found among the Jews". The Pasha, who had been previously trying to convince Barbarigo to procure him red silk for his daughter, replied irritated "cannot then Jews, by any chance, bring fabrics into Venice?146

To be sure, the only source of normativity in Ottoman judicial practice was sharīa, and the procedure followed at the Divvān tended to mimic that in use in the qadi courts. Yet the Abdellatif and similar affairs suggest that there existed alternate paths for the handling of sensitive legal issues at the Imperial Council. Transfer from the pashas, more sensitive to the logic of kanun and customary law, to the stricter sharīa-based viewpoint of the kadıaskers was undesirable, at least from the point of view of Venetian interests. This, again, was in stark contrast with the widely-accepted Mamluk procedure to leave decisions involving foreigners in the hands of the emirs and officials. In an episode I examine in the next section, the kadıaskers made a sound defense of the necessity to rely only on Muslim witnesses for borderland issues, although Burletto's story proves that they were equally vigilant about the alarming proliferation of false witnesses in the imperial capital.

\subsection{Proving Enslavement}

The Dìvān was a privileged place for observing the confessional meaning given in Ottoman times to issues of proof and evidence, not only from the government's side but also for other subjects on the legal system. Endless conversations between the Venetian bailo, his secretaries, the pashas and the kadiaskers revolved around procedural and evidentiary matters, and mostly around the

\footnotetext{
145 "Et dapoi alcuni quesiti fatti per il signor bassa, sua sia. Disse che bisognava che io aprobase questi piezi, li fu risposto che io non podevo impedirmi, il cadi laschiero li notò piezi in sigiletto, et poi fezeno che il magnifico dolfino dette in nota alquante sue robbe.", ASVe Senato, Dispacci Consoli, Egitto B1, 14.

146 "non possono forse hebrei portar panni in venetia?", ASVe, Senato, Dispacci degli ambasciatori e residenti, Costantinopoli B. 1A, 473-4.
} 
need to prove claims through the means of a qadi's sijill and before Muslim witnesses. Historians have devoted a great deal of effort to understanding the mechanisms behind the phenomenon of ransoming, a practice that emerged as an expression of early modern cross-confessional coexistence. For the bailos, it was instead the recovery of prisoners that was rife with conflict, and they saw the witness system as the principal device that biased the legal system in favor of Muslims. Reports addressed to the Senate by the ambassadors bitterly complained about the manner in which slave-owning disputes were conducted.

The relazione, or conclusive report, by Antonio Rizzo, read before the Senate in 1557, deals extensively with borderland attacks involving the seizure of Venetians, and the difficulties experienced by those attempting to free the prisoners. Rizzo presents three major scenarios of maritime attacks and the subsequent arguments put forward by the Ottomans to support their decisions. Two of these scenarios concern captives, and the third involves the requisition of cargo. According to Rizzo the first line of defense against returning captives held that the offenders were corsairs, acting in isolation and therefore not subject to the sultan's obedience; they therefore could not be punished, and in any case Ottoman officials, as interested parties in these misdeeds, would not enforce corrective decrees addressing the issue. The second scenario regarded damages caused by men who could not deny their Ottoman status; the pashas' strategy was generally to deny any involvement, or the existence of any proof of it. This was a particularly difficult argument to counter, Rizzo argues, because in the borderlands the only witnesses present were those who had inflicted the damages and those who had suffered them. Admittedly, the former were not willing to talk, whilst the latter could hardly be given any credit, both for being the plaintiffs and because of their being Christians. "They [the Turks] call the latter giauri, or infidels, whose testimony is not accepted against Muslims." In other words, because there were no unbiased witnesses present to attest to their enslavement, it was impossible to secure the release of such captives.

The third maritime scenario described by Rizzo regards the requisitioning of cargo on Venetian vessels, which, it was claimed, often belonged to Ottoman subjects, and whose seizure was therefore not illicit. Rizzo goes on to mention the recent confiscations by Dragut Bey in Corfu and by the Beylerbeyi of Algiers Salah Re'is (1552-1556). In these cases the witness system, he argues, hampered any redress for the Venetians. ${ }^{147}$ In both episodes, according to the

147 On the same episode, copy of a letter by Secretary Giannesino mentioning the investigation (taftīsh, it. teftes) to Dragut, Amasia, 19 Feb. 1554, ASVe Senato, Dispacci Ambasciatori e Residenti, Constantinopoli. B. 1A, 79r. 
relazione, the confiscated goods were not returned to their Ottoman owners, who were themselves enslaved. These captives, when reclaimed by the Venetian authorities, needed again to prove their free status by means of Muslim witnesses. At this point, Rizzo's narrative appears somewhat contradictory: who are, one wonders, these Ottoman subjects whose goods and freedom are the bailo's concern? Rizzo here elaborates on an episode that happened during his tenure, narrated in his regular reports (dispacci) preserved in the Senato, Dispacci Costantinopoli series. These reports refer to a highly disputed case where the Ottomans of Rhodes captured three vessels and conducted them to Constantinople. The ships were transporting irregular troops of Greek stock - it. levendi - who had allegedly deserted Turkish ranks. The ships arrived in Istanbul, upon which Rizzo was alerted to the suspicion that the ships might be carrying Venetian subjects; he managed to trigger an official investigation to ascertain the presence of Venetians, first at Constantinople's arsenal, then at the Divann before the pasha. Rizzo conducted a delicate negotiation in order to identify, before Muslim officials, a group of twenty-five Venetian subjects from Zante, Corfu and Cephalonia previously captured and put to the oar by the levendi. Playing his cards carefully at the Dīvān, Rizzo soon obtained the release of the Venetians on board the ship. ${ }^{148}$ Marcantonio Donini, the bailo's secretary, adds in a relazione written shortly afterwards that the levendi manned their galleys principally with Venetian prisoners, and that before they called at Istanbul they dropped these prisoners off at Mytilene for fear of the bailo having them freed. Ostensibly, the levendi preferred to sell captives unfit for the oar in Anatolia, since in the Aegean it was more likely that the Venetian authorities would get wind of their presence and intervene on their behalf. ${ }^{149}$

148 "Sua m. mi dimandò, se io sappea li nomi d'essi, gli risposi, che io non li potea sapere, perche erano stati presi in diversi tempi, et che sono homini di bassa sorte, laqual mi disse, chel bisognava pur veder per giustitia se fusero stati comprati, overo come fussero stati posti alla cathena, io non volsi risponder all'hora, che a niun modo poteano esser schiavi per $[207 \mathrm{r}]$ metter la cosa in disputa, fino che non fussero levati dalla cathenali schiavi; ma le dissi che non volea altra giustitia che quella delle magnificentia sua; la qual pregava che fusse contenta mandar uno delli homini sui con un mio dragomano per riconoscere li schiavi, accio non fussero strabalzati, perche poi io non temea della giustitia, et gli replicai, che non volea altra giustitia che di sua magnificentia, la quale principio a ridere, et mi disse, che volea servirmi di buon inchiostro, et che volea mandar a chiamare il prothogero del capitano di Rhodi, et intendere questo fatto. Io, sebene non mi piacque molto questo principio, pur non possendo far altro dissi, che era contento," ASVe Senato, Dispacci Ambasciatori e Residenti, Constantinopoli. B. 1A, 206v-207r.

149 "sudditi di Vostra Serenità, delli quali se ne pigliano alcuno che a ciò non sia atto, lo vendono o barattano più presto nella Natolia che in altre parti, perchè in luoghi vicini a quelli della Serenità Vostra non ritrovano cosi facilmente quel che vogliono d'esso, dubitandosi li 
Failing this, their abductors arranged for Islamic witnesses who could attest to these captives having debts and bonds of servitude for their masters, or sometimes forced them to acknowledge debts so that their masters could legally reclaim these sums as ransom. ${ }^{150}$ In his final report to the Senate, Rizzo uses the episode of the Venetian captives to blame the Ottomans' attachment to the witness system.

In such cases goods are never returned to these subjects, since they are conducted as slaves, and when your Grace the Prince requests their release they pretend their free status to be proven by Muslim witnesses, which, being difficult enough as regards the goods, I judge is in every respect impossible to obtain as concerns the latter, something aggravated by a legal bias making it impossible to free giauri slaves from the Muslims' hands. ${ }^{151}$

For Donini, the pashas admitted the damages but required Muslim witnesses to assess the losses. ${ }^{152}$ Lastly, Rizzo indulges in the cliché of chained Venetians paraded before their own representatives ("sopra la faccia delli rappresentanti suoi"), claiming that in spite of his good offices most slaves were sent to Anatolia, from whence they would never return. The cliché has a characteristically early-Ottoman flavor; seventy years earlier, the scene was depicted by Zuan Dario in almost the same terms, stressing that these captives displayed before the consuls in chains were enslaved during peacetime. ${ }^{153}$

compratori che in qualche modo quel tale gli debba esser levato dalli ministri," Relazioni degli ambasciatori veneti al Senato, Serie III, Volume III, 194.

150 "quando loro occorre venire a Costantinopoli per alcun negozio della Maestà Sua, lasciano li schiavi, se sono sudditi di Vostra Serenità, o a Metelino o in qualche altro luogo, dubitando che dalli clarissimi baili quelli siano fatti liberare; e se pure ve ne conducono alcuno, dicono e provano per testimonj musulmani che li hanno comprati, o che hanno loro prestati danari con obbligazione ch'essi li abbiano a servire per qualche numero di anni nella fusta o galeotta loro, facendo appresso ch'essi medesimi schiavi confessino l' istesso per forza di bastonate di modo che li detti leventi offeriscono poi essi schiavi per la quantità del danaro ch'hanno detto aver esborsato come di sopra, e a questo modo non v'è rimedio di poter liberare alcuno di loro," ibid., 194-5.

$15^{1}$ Ibid., 143 .

$15^{2}$ "volendo che per musulmani sia fatta la giustificazione della qualità e della quantità di essi danni. Il che quanto poi sia difficile a farsi, lo lascio considerare alla molta prudenza e ottimo giudizio della Serenità Vostra; alla quale, per mancamento di tali testimoni, da alcuni anni in qua sono stati fatti tanti danni di gente," ibid. 195-6.

153 "hauaua molto dispiacesto ala v.ra .S.ta et anche ogni zorno li reclami che vano a venexia de li dani fati et de questi nostri captiui fati in tempo de paxe strasinadi in cadene auanti ali nostril ochii.", Dario, 22 dispacci, 110. 
The fact that all decisions of royal justice were referred in the last instance to the sultan contributed to placing the biases at the center of an Ottomansponsored legal order. An early occurrence of the problem can be found during the tenure of Bailo Pietro Bembo; in the course of negotiations at the Dīvān concerning Venetian slaves, the pashas eventually withdrew from their initial concessions, on the basis that Muslim witnesses were needed. The pashas approached the Venetian diplomats gently, arguing that the sultan himself "wants no prisoner to be released without Muslim-produced proof." Allegedly, the pashas had interceded on behalf of the Venetians: "they have no Turks to prove it," an argument against which the sultan "stood firmly" with the justification that "he did not intend to contravene their own law."154 On another occasion, Zuan Dario brought the question up in the course of a conversation with Mehmet Pasha, a deputy of Grand Vizier Koca Davud Pasha (1482-1497). Both men were discussing the effects of borderland strife in Albania and Morea, which had provoked a worrying increase of the seizure of captives. Dario took advantage of the friendly tone to mention the shortcomings of requiring "Turkish witnesses, that cannot be found in our lands," however Mehmet Pasha only "shrugged his shoulders, saying he could not contravene his people's faith."155 Dario closes his narrative by declaring himself "an instrument of two powerful states diverse in language, costume, and law."

Bailo Bembo was not the only representative to mention the flow of miserable slaves aboard ships from Corfu and "lost places" such as Valona. After an initial stop at Gallipoli, in the absence of sharīa-compliant testimonies, the

154 ASVe Senato, Dispacci Ambasciatori e Residenti, Constantinopoli. B. 1A, 22 april 1484, "Innocupato chome eramo e maxime circa questi miseri schiavi che se atrova presenti et chi sono per venire sperandoche per le cosse tratate per Ser Zuan Dario se dovesse miorar le condition nostre in quelli alla qual parte venuti con essi bassà con parole dolce et humane resposeno chel signor non voleva ne havessamo alguno senza prova de turchi et che loro bassa lihavea dito nui diseamo non haver turchi da probar el signor fermo digando non voler contravenir alle leze soe e che non sene parlasse piui. Poi [...] molti altri che per comandamento de questi bassà erano stati mandati da la turchia per uno schiavo per loro mandato de la qual alguni garzoni fati turchi et tolti da le man di padri loro dei altri non trovando prove di turchi hali ttornati alleso padroni che questi bassà se defendeno con el signor che non vogi e mi credo che loro siano quelli." Bembo stumbled upon the same difficulties regarding some captives from Corfu shortly afterwards: ASVe Senato, Dispacci Ambasciatori e Residenti, Constantinopoli, 17 June 1484, $10 a$.

155 "li dissi poi del fatto di schiaui et del torto che ne veniua fato a domandare testimonij turchi che non nasseno nei nostri paexi. el strense le spale digando non poder contrauenire ala lor fede. li respusi che non era possibille che fosse bona paxe intra de nui se non se meteua qualche bon mezo a questa cason [...] ma per tornar al fatto mio Ser.mo principe io me trouo hauer gran cargo su le spale atrouandome instrumento tra do cusi potentissimi stadi diuersi de lengua de leze et de costumi." Dario, 22 dispacci, 102. 
resident bailo could not prevent the captives' definitive departure for Anatolia. Transfer to the hinterland seriously affected captives "of lower stock," a practice about which the ambassadors in Egypt also complained. When Franks were enslaved, the Venetians argued, if the consul invoked the clauses in the treaties that forbade this practice, high-ranking Egyptian owners made these slaves disappear. Indeed, these captives were forced to sign acknowledgements of debt and other written contracts, so that the treaties' dispositions would be invalid. According to several dispatches from Cairo, slave owners took great care to have these agreements notarized so that they could not be abrogated. ${ }^{156}$ Contrary to the Maghreb, where a institutionalized 'ransom economy' emerged, in the Levant the rigid application of the Islamic laws of evidence impinged over definitions of foreignness and captivity. According to Suraiya Faroqhi, individuals were often imprisoned as fugitive slaves, then released after proving their free status. Manumitted slaves needed to possess hujjas certifying their freedom, since a particular kind of bounty hunters could lawfully capture escaped slaves, and they "might claim that whatever strangers they encountered were escaped slaves." 157

By bringing up the contentious issues reported by Venetian representatives, it is not my intention to present the Islamic regime of proof as a mere device for covering up all misdeeds. Neither were the Venetians, in spite of some bitter relazioni, such as that sent by Rizzo-omitting his successful recovery of twenty-five captives-ignored of the fact that false claims were often overthrown on the very same procedural grounds. Alvise Mocenigo, ambassador to sultan Selim after the conquest of Egypt, admitted a pasha's goodwill, after an attack to Naxos and Mitylene by Kurtoğlu Muslihiddin Reis (1487-1535), in sending orders to qadis and officials in Anatolia to return to the Bailo the eventual prisoners being sold after the event. ${ }^{158}$ Bembo mentions in his dispacci a group of slaves forcibly converted to Islam who were returned to the Venetians, since no Muslim could attest to the validity of their enslavement. By the same token, a judge's suspicions could be aroused if he found the versions delivered by slave owners unconvincing, as in the case of a young citizen from Bergamo whom the bailo managed to have freed. ${ }^{159}$ Cases of captives fleeing to Venetian

${ }_{15} 6$ "li fanno per sigilleto di cadi, che è impossibile tagliarli.", ASVe Senato, Dispacci Consoli, Egitto B1, n.42, n.46.

157 Faroqhi, Suraiya: A cultural history of the Ottomans. The imperial elite and its artefacts, I.B. Tauris, London-New York, 2016, 87-8.

158 Sanudo, Marino: I diarii di Marino Sanuto, edited by F. Stefani, Nicolò Barozzi and G. Berchet, Venezia, 1889, Vol. xxv, 274, 564 .

159 ASVe Senato, Dispacci Ambasciatori e Residenti, Constantinopoli. B. 1A, dispacci Pietro Bembo, 22 April 1484. 
lands, such as Crete, were often discussed, and concerned Ottoman officials pleaded their cases at the Dīvān by producing Muslim witnesses, often sending deputies to collect such testimonies from places as far as Naxos. Ottomans advanced grievances concerning dhimmīs who had abandoned the sultan's domains and settled in Venetian territories, as in the case of a large group of carazari migrants to Lepanto. ${ }^{160}$ The Venetians often had to deal with these claims in exchange for concessions regarding their own subjects. "Do you realize the courtesies we grant to your subjects?" a pasha asked the bailo after a kadiasker had released a Venetian ship to satisfy the complaint of an Ottoman Jew. ${ }^{161}$ In their conversations with the pashas, the consuls and ambassadors admitted that the object of their complaints were false witnesses and arbitrariness, rather than to challenge the sultan's justice and its procedures. ${ }^{162} \mathrm{~A}$ pasha explained to Dario that, if Muslim witnesses were sometimes impossible to find, neither could the pashas simply accept the bailo's word on the matter, since claims concerning Christians from many different places, ranging from Germany to Puglia, were heard and examined at the Dīvān, "so that our judgment would not seem biased or suspicious."163 The examination of witnesses, Italianized as teftes (ar. taftīsh) emerges time and again in the dispacci literature, and is proof that the Venetians were more familiar with sharīa procedure than is often assumed. ${ }^{164}$ However discriminatory it may appear, the defense of the witness system cannot be labeled as simply opportunistic — and indeed this is epitomized in the reprisals against Burletto. Not only Muslims, but also the carazari sponsored the discrimination of witnesses on religious grounds. The Venetians, on their side, seem to have accepted the witness system to be part and parcel of the Ottoman version of the legal system, and one of the foundations of Islamic sovereignty. The bias against minority witnessing was not felt simply as an imposition, but perceived as point of doctrine that played out in the daily practice of bilateral relations.

\footnotetext{
16o Dario, 22 dispacci, 148.

161 "voi vedete quello che noi facemo per li homeni vostri?" ASVe Senato, Dispacci Ambasciatori e Residenti, Constantinopoli. B. 1A, 374-6.

162 See Bailo Antonio Rizzo's speech reported in note 148.

163 "et li patroni di schiaui sempre diriano esser sta inganadi dal Baylo per che luno cristiano aiuta laltro et aliberar schiaui ogni vno e in clinado da la natura ma la via del mezo seria questa che messe da canto le leze nostre cusi strette. nui Bassa insieme cum vui fossamo cognitori de questa facenda et che ne fosse apuntadi li schiaui et che li vedessamo et aldissamo et considerade le circonstantie li zudegassamo et chel nostro judicio seria perfetto et non seria suspetto," Dario, 22 dispacci, 94.

164 Heyd and Ménage, Studies in old Ottoman criminal law, 228-9.
} 
Issues of religion and political identity impinged upon, and often complicated, the outcome of disputes. Christians captured in the Ottoman territories were forcibly converted as a means to prevent their restitution, probably because hanafi jurists objected to return Muslim slaves on the basis of dhimmī testimony (since non-Muslims converted after enslavement remained slaves). ${ }^{165}$ Conversely, episodes in which Muslims were the object of forced conversion were often heard at the Dīvān, about which the "pashas seemed very angry." Bailo Barbarigo mentions a complaint filed at the Dīvān in 1557, concerning two hundred Muslims put to the oar in Venetian galleys off the coast of Cyprus, according to a written report by a captive sipahi forced to convert. ${ }^{166}$ Religious issues arose when a Venetian outlaw-a nurtured community in Constantinople described by Eric Dursteler-laid claim on the property of a certain Niccolò, a Cretan mariner stuck in Gallipoli for over two years. The Venetian dissident filed a complaint before the qadi, allegedly bribing him, and produced two witnesses backing his claims over Niccolò. According to Bembo, who was clearly suggesting that evidentiary standards were not always observed, a closer look revealed that one was a manumitted slave of the plaintiff, and the other an eighty-year old man. Muslim jurists generally sketch a typology of valid witnesses, excluding those who had some kind of power relationship with one of the parties, as well as the disabled, but as we have seen a manumitted slave qualified as witness. As I claimed in the section devoted to false witnessing, the Ottomans' attachment to the biases against minority witnessing favored the proliferation of forged testimonies, an issue that was of great concern to the authorities. Quite theatrically, the mariner was carried away from the court crying out before the qadi and everyone present "I am a Venetian and a free man, and I have never been a slave before." Bembo then complained of the difficulties brought about by the exercise of justice as applied by the Ottomans, which, as we have seen, limited the taking of legal decisions to the sultan's court. "Had the court been there or in Adrianople, I would have rushed to protest ...", "If the Porte was here I would have complained so loudly that I would have probably been heard," the bailo argues. Indeed, by the late fifteenth century, the Ottoman court was still itinerant, and as mentioned in the treaties, in case of the absence of the sultan the Divvān-ı Hümāyūn handed petitions to a chief qadi, before the institution came to be dominated by the grand vizier and his bureaucracy in the seventeenth and eighteenth

\footnotetext{
165 Ibn Nujaym, al-Ashbāh wa-al-nazāäir, 284.

166 "uno spachi che aviano fatto far christiano per forza, la qual querella stata letta in divano haveva molto alterati tutti essi bassà," 26 September 1557, ASVe Senato, Dispacci Ambasciatori e Residenti, Constantinopoli. B. 1A, 437-39.
} 
centuries. ${ }^{167}$ Decisions invariably appeared to have been taken personally by the sultan after consultation with the pashas, yet in case of his absence, Bembo argued, the verdict issued by a "crazy qadi" led to the definitive enslavement of Niccolò and his eventual transfer to Anatolia. ${ }^{168}$

\subsection{Legal Truth and the Governance of Frontier Zones}

The pashas were sensitive to similar claims on religion advanced by their Christian counterpart, provided they were compliant with Islamic standards of proof. Bailo Antonio Rizzo vividly describes the stay of a Rumelian bishop in Istanbul, during which he lobbied to free a large contingent of Bosnian Christians. The bishop brandished a "stash of notarial deeds" to support his claims, with statements by both Franks and "honorable Muslims". The bishop had been laboring in some episcopal sees, then in Naples and in Rome to obtain a papal decree (defined as "an excommunication") on the grounds that these slaves' masters were themselves Christians. Eventually, the strategy proved to be successful, thanks to the bishop's perseverance with the pashas whom, just like the bailo, he visited and entertained at their private residences. ${ }^{169}$

167 Atçil, Procedure in the Ottoman court and the duties of kadis, M. A. Thesis, Bilkent University, 75-6, Baldwin, Islamic Law and Empire in Ottoman Cairo, 39.

168 "aviso la vostra Magnificentia come era de qui uno candioto nominato Nicolo el qual era de qui fin la rota de la nave de Nicolo Caro che do anni e mezo passati et a hora se hatrova uno ribaldo che disea quello esser suo schiavo et halo menado avanti allo cadi apresentado do testimoni. L'uno era so schiavo franchado e laltro vechio de anni 8o. Esi testi dicono che lera so schiavo. Lo cadi che havea manzato l'a sentententiado che lel debi menar via per so schiavo et sta menà in l'Anatoli. El povero gridava e son libero e venetian e mai non fo schiavo in tempo de la mia vita pocho me ha valesto el mio gridare avanti el cadi e de tuti de questo locho; dio lo sa che se fosse sta la porta li o in andrinopoli seria andato a far lamento. Per tanto puol intender la vostra magnificentia la inzuria che ne fa questo mato del cadi [...]. Quello che con questi mezi puol seguir non el voio dechiarir perche per si medemo el se intende. Io non ne saperia dar remedio non so che altri che Dio el possi far. Pur se la porta fosse qui gridaria tanto che forse seria aldido. Idio proveda lui chel po far." ASVe Senato, Dispacci Ambasciatori e Residenti, Constantinopoli. B. 1A, Constantinople, 14 July 1484.

169 "appresso le quali haveva molti sigilletti de sanzachi, cadi, et nasiri, che attestavano a questa porta, che un numero di cinque, et piu mille homeni sudditi di questo serenissimo sr erano ritornati alle case loro (...) Con queste attestationi introdussi esso reverendo episcopo al magnifico bassà, et dissi à sua $\mathrm{m}$. Che vedendo io per molti sigilletti de mussulmani honorati, et anco de nostri, questo essere assai benemerito della eccelsa porta, lo raccomandava assai alla $\mathrm{m}$. Sua, alla quale lui esponerebbe li particolari della causa sua. Sua $\mathrm{m}$. Lo fecce introdure, alla quale lui presentò uno gran fasso di sigilletti che faceano fede ...", ASVe Senato, Dispacci Ambasciatori e Residenti, Constantinopoli. B. 1A, 297. 
Language and personal affinity played their part, too, in the eventual success of negotiations; the bishop and the pasha communicated in a Slavic language, in the same fashion Zuan Dario claimed his knowledge of Greek to have granted him the favors of his counterpart at the Divvān. This Greek-speaking pasha, in passing, was eventually dismissed from the Dīvān due to his excessive proximity to the Venetians. ${ }^{170}$ Yet it was ultimately the series of documents drafted "by qadis, sanjakbeys and nāzirs," advanced by both the bishop and the bailo, that procured the former the leverage needed for his mission. In this, slaveownership disputes did not differ much from other borderland quarrels. Zuan Dario spent a great deal of time discussing the issue of a bridge that had been built on the fringes of Ottoman Bosnia; the discussion revolved around whether the bridge had been built on Ottoman territory, and on the reasons behind its construction. Dario wanted the bridge to be demolished since, he stated, it facilitated Ottoman raids in Venetian Dulcigno (Ulcinj). The Dīvān sent an inquiry to the qadi of Scutari, who replied that the bridge was a pious foundation built, in accordance with religious law, for welfare purposes. An Ottoman official summoned to the Divañn argued that the artifact had saved the lives of local peasants, who often drowned crossing the river. The debate soon got bogged down into an inquiry on whether or not the borders had been agreed upon by the Venetians and Ottomans and properly notarized, and on the availability of such documents. The pashas pushed the bridge affair into the terrain of religious legitimacy, insisting that it was a waqf founded on the sultan's lands, and summoning Ottoman qadis to the Dīvān to attest to its status as a pious foundation. Dario, irritated, ended up acknowledging that the pashas' attachment to religion, and the absence of sharīa-compliant records, made the issue impossible to resolve. ${ }^{171}$

A similar climate of religious orthodoxy was felt during a discussion between the bailo and Rustem Pasha (d. 1561) regarding frontier disputes near Vrana, in today's Croatia. The Bailo had presented Venice's willingness to discuss borderline disputes in the area and to withdraw the complaints advanced by Venetian subjects. The sultan had agreed that a new taftish, or witnesses' examination,

170 "missith Bassa era cului che respondeua: compositamente et anche benignamente per esser sta de nobillissima fameia et ben dotado de la natura: et erame molto comodo per la lengua grega che in verita molte fiade me aiutaua dove che li turcimani non afferauano ben le materie" [...] "et el zorno seguente siando zorno de vacacion el pouere zentilhomo ando a spasso a zerto so zerdino vecino ala terra dove li fu subito ala coda un messo de Alma el qual li anuncio per parte soa como laueua casso de Bassa e non voleua che vegnisse pui ala porta", Dario, 22 dispacci, 170.

171 "dixeuano che quel ponte era fabricado per elemosina perche le vna de le opere pietose comprexe in ne la leze loro" ibid., 214. 
should take place in order to ascertain these disputes. Venice's position, the bailo insisted, required "examination of Venetian testimonies upon a foot of equality with Muslims, so that justice can be achieved on both sides." Rustem Pasha objected that he believed this last point to be "forbidden by our laws (canoni)," but suggested that the bailo advance his claim at the Dīvān, and committed to personally intervene in the bailo's favor. At the Imperial Council, once the bailo had done as advised, the pasha turned to the kadiaskers and asked them to draft a petition to the sultan for the admission of Venetian subjects as witnesses. The latter replied that such a request did not comply with the law ("non essendo ... de iure"), and was "totally forbidden by our canons." The bailo eventually invoked the carazari clause for disputes involving Franks and dhimmīs—Christian Morlachs in this case—arguing that in the dispute in question both communities were able to give testimony. "Be patient" Rustem Pasha enjoined the bailo, because "if I addressed such a request to his Majesty he would take offense against me, knowing this goes against the law."172

To be sure, the tone of the discussions described above is evocative of the peculiar, political nature of Veneto-Ottoman relations. In the last decades, historians have turned away from the so-called "ghāzi paradigm" to focus on the intense borderland mobility found in areas such as the Balkans or North Africa, or on the crossing of community boundaries in places such as Istanbul. It was the Dìvān, however, that became the fulcrum for cross-confessional diplomacy, and in order to understand the political relations that were played out in it, we need to take into account the importance given to Islamic notions of

172 "dicendoli che havendo vostra Serenità intesa la deliberatione $[. .$.$] di voler che da novo$ sia fatto teftes sopra le querele passate ... sopra li ditti confini et che per cio la havesse a mandar uno suo agente sopra il loco, la era contenta di satisfare a quello che sua magnificentia desiderava ancor chel fosse superfluo [...] era che le nostre giustificationi fossino tolte, et li nostri testimoni essaminati. qui a voler che la giustizia fosse pare da una parte et dall'altra... il qual mi rispose, io credo che questo sia prohibito dalli nostri canoni nientedimeno ne faro arz al Signore et savendogli io ditto di darli uno Arz sopra di questo nel qual fossero dechiarate le nostre ragioni, mi disse non atendo lassa pur far a me, onde alli 16 del presente andai in Divano per proponergli questa materia, laqual fu da me esposta con li stesse ragioni sopradette, per il che il bassa volto alli magnifici caddi laschier disse, che dovessino farne Arz al Signore li quali risposero che non essendo questo da iure, et del tutto prohibito dalli loro canoni, non volendo far Arz altramente, replicai le ragion nostre piu di una fiata, allegando quel capitulo della pace nostra disponente che nelle differentie, che nascerano tra vostri caraciari, siano admesi testimoni christiani di qualunque sorte ne fu modo che volessino admetterle di modo chel bassa mi disse, non se potendo far tal cosa, habbi pacientia, perche se io ne facesse Arz al Sinore sua Mta. si sdegneria contra di me, sapendo eser contra li canoni," ASVe Archivi Propri Constantinopoli, 1, fasc. IV, 162v, 20 April 1547. 
proof and evidence. At the Imperial Council, more than in any other place, the biases against minority witnesses served the purpose of marking an invisible line between the two promiscuous empires and their porous borderlands. This importance is apparent in the numerous discussions over the ownership of both human bodies and physical space, and their outcome did hinge on the religious roots of legal normativity. Red lines were drawn over sensitive issues and seriously respected, such as the jurisdiction over criminal disputes involving Muslims. For example, in 1558 Bailo Barbarigo asked the Porte permission to judge a Turk who had committed serious crimes near Spalato in Venetian dominions, plundering a monastery and having some monks slain. For Barbarigo, territorial notions of law were universal, but they contrasted with the pasha's views on the personal nature of sharía, who saw it as having jurisdiction over all Muslims, irrespective of where they lived, particularly in criminal cases. "The sultan" he argued, "shall never grant you such a ruling, since he does not wish for you to put a Muslim to death."173

It would be misleading, however, to see religious discrimination as an overarching category, imposed from above, and conditioning all decisions. If the Porte often justified its position on religious grounds, other actors too, used religion to gain the necessary leverage in commercial litigation. In a most telling account, Hasan Çolak has shown the instrumental role played by Muslim witnessing in changing the status of the City of Istanbul under the patriarchate of Ieremias (1522-1545). Through an expert recourse to Muslim testimony, the Patriarch managed to counter Ottoman attempts to confiscate the churches of Istanbul. These claims, raised by a kadıasker at the Dīvān, were grounded on the legal argument that, if a city is taken by force, then there should be no Christian churches in it. Accordingly, a fatwā had been issued with the injunction of destroying the churches within five days. While the claim that the city had been taken by the sword stemmed from historical accounts found by the Turks "written in their papers", the Patriarch proved able to summon two watchmen who had witnessed the Ottoman takeover in 1453. They attested to the fact that it had been eighty-four years since the time Sultan Mehmed took Constantinople not by force, but upon agreement, and that they were

173 "Nelli luochi nostri doveva anco dalli rapresentanti (di) Vostra Serenità esser castigado cosi per quello e stà osservado sempre come per ogni raggion et leggi del mondo, rispose il bassà questo commandamento non vi concederà mai il gran Signore, per che non vorrà che voi possiate far morir un Mussulmano, ne li capitoli che havete manco lo vogliono, quali dicono che abbiate a consignar gli huomini in man nostra et noi habbiamo conossuto il suo fallo castigargli," ASVe Senato, Dispacci Ambasciatori e Residenti, Constantinopoli. B. 1A, Constantinople, 406-7, 2 May $155^{8}$. 
eighteen years old at that time. The watchmen orally confirmed the alternative narrative whereby the emperor Constantine handed the keys of the Castle and bowed in front of the sultan. As a result, the sultan issued an imperial order so that the Christians would not be disturbed. The fact that witnesses were aged 102 at the time do not seem to have impinged on formal validity of the decision. ${ }^{174}$ By the same token, and notwithstanding the crucial importance of the witnesses' faith, Abdellatif's or Burletto's cases suggest that blackmailing the judges over religious grounds did not always work. Rather than raising a 'bronze wall,' around the Muslim community, in the daily life of diplomatic and legal encounters, the biases played out in relations that were political in nature, rather than in the context marked exclusively by economic interests or military rivalry.

\subsection{The Aleppo Ferman}

It is clear at this point that diplomatic discussions at the Dìvān often addressed the harm caused by the enhanced role of testimonial evidence. Some of the discussions held between the bailo and the pashas make it clear that not only the mustā'min and the carazari advanced claims over the use of witnesses, but also Muslims. Indeed, it seems that the Muslim merchants of Aleppo may have lobbied for, and obtained, a ferman stipulating new special conditions for the use of Muslim witnesses in mixed cases. Taking place in 1557, the episode should be read against the backdrop of Ottoman adjustments and exceptions to general evidentiary law, and in particular, the rule on the inhibition of witnesses when qadi-notarized documents were available. This development is important for several reasons, but first and foremost because the new decision contradicted a superior principle that had become a central issue in the legal order sponsored by the dynasty. In fact, the decision to set different evidentiary standards for Aleppo suggests that, elsewhere, in the main Ottoman cities, the principle invalidating Muslim witnesses against Franks had become customary.

Unfortunately, the story's contours remain, as in previous cases, murky. We know that grievances began to arrive from Aleppo, and that they concerned "foreign" Muslim merchants. Apparently, these foreign merchants struck deals with Franks, or at least with the Venetians. We cannot know from whence these merchants originated, although it is unlikely that they came from other Syrian

174 Çolak, Hasan: Co-existence and conflict between Muslims and non-Muslims in the 16th century Ottoman Istanbul, MA thesis, Department of History, Bilkent University, 2008, 38-65. 
cities, where Ottoman laws would have been known; in any case, the bailo's report on the Aleppo ferman probably refers to Persians involved in the overland silk trade that had been experiencing a boom in the last few decades. Be that as it may, these business deals often turned bad, and the cheated foreign Muslims sought redress from the qadi courts. The bailo acknowledged having received letters from the consul in Syria, who requested that the former seek the abrogation of an imperial decree granted a few months previously to the beylerbey and the qadi of Aleppo. The ferman in question allowed the qadis to summon Muslim witnesses for or against Frankish defendants, in cases where the other party were Muslims, meaning not local, Aleppine merchants, but "foreign," hailing "from outside the country."175 The consul argued that once a complaint against Franks had been filed, these foreign Muslims were informed that the Ottoman sultan had forbidden the use of Muslim witnesses in cases against the Franks. Whoever they were, the Muslims in question seem to have seen this measure as completely aberrant, and in any case their complaints soon reached Istanbul. Since they were ignorant of the ban on Muslim witnesses, foreign Muslims would have concluded business deals without requesting the necessary hujja from the qadi courts, hence remaining unprotected in case of a lawsuit. The beylerbey and the qadi of Aleppo obtained a decree stating that Muslim witnesses would not be heard for cases concerning the Venetians against local, Aleppine merchants, but that this could be permitted in mixed cases involving Franks and "foreign" Muslims. ${ }^{176}$ These foreigners, according to

175 "Lettere dal consolo della Soria [...] che mi ricercano a dimandar revocatione di un commandamento già alcuni mesi ottenuto à questa porta dal magnifico Beglierbei, et Cadi di Alepo, che con li franchi possano esser essaminati testimonii musulmani quando essi habbino differentia con mercanti, che non siano del paese, attento che loro, non sapendo il commandamento che già fece il gran signor che non fossero contra franchi admessi testi musulmani, venivano defraudati da nostri, ne mai potevano aver il suo, andai al magnifico Bassà, et con ogni efficace forma di parole esponendogli li disturbi che ogni dì seriano seguiti alli nostri per questo commandamento del tutto contrario alla prima intentione de sua Magnificentia et all'antiqua usanza lo pregai per giustizia, et quiete delli predicti mercanti, li quali erano di tanto utile alle scalle sue, che volesse darmi la revocazione, et egli mi disse che mandasse il secretario a divano che uderia detti comandamenti, et mi risolveria, et cosi mandatolo, la mattina ebbe in risposta che non si poteva rimovere detto commandamento perche era sta ordinato dal gran signore di bocca propria, et poi era necessario per li predicti mussulmani forestieri, per prohibire che non fussero di continuo ingannati, il secretario a questo secondo che gli aveno commesso le disse che poteano piu facilmente li nostri mercanti anco loro forestieri esser ingannati, che loro ingannar altri, ma che se pure la magnificentia sua aveva questa oppinione." ASVe Senato, Dispacci degli ambasciatori e residenti, B. 1A, 385 .

${ }_{176}$ "et letta che la hebbe parve che rimanesse sodisfatta, poi gli esposi il desiderio che aveva Vostra Celsitudine che fusse per la Magnificentia sua revocato il commandamento 
the beylerbey and the qadi, "are not familiar with the decree Our Lord issued banning the use of Muslim witnesses against the Franks," and, as a result, "they were being cheated by our merchants, and were never able to retrieve their money." The bailo hastened to the Dìvān, arguing to the pashas that such an annulment, apart from being prejudicial to the Venetians, was contrary to the sultan's will.

Far from being a minor issue, the affair of the foreign merchants in Aleppo was included in Venice's diplomatic agenda in the following months, but the Porte upheld its original decision to make an exception for Aleppo. ${ }^{177}$ The bailo protested on the grounds that the new decision contradicted superior norms, but the pasha replied that as long as the foreigners were ignorant of the standard ban on Muslim witnesses they would be easily deceived. According to Bailo Barbarigo, it would have been simpler to have had the measure announced by criers at the markets, or notified by the simsārs present to witness business deals. For Barbarigo, the measure threatened the property rights of Venetians, not only in their deals with foreigners, but also with local Muslims "acting in bad faith." Indeed, in the latter instance, the problem with the commandamento was that it departed from sharía. By distinguishing between local and foreign Muslims, it implied a territorial aspect that is fundamentally foreign to the personality of Islamic law. Indeed, in that same year the Porte had intervened in favor of some Muslims of Granada imprisoned in Venice at the request of the Spanish ambassador, on the basis that, as Muslims, they were subjects of the sultan and therefore were protected by the ahdnames. ${ }^{178}$ Far from representing a mere anecdote, the Aleppo ferman is evocative of the fundamental shift brought about in the 16th century as regards the handling of cross-confessional relations. Whereas medieval sultans took great care to leave legal doctrine in the hands of the religious learned, the Ottomans sponsored their own solutions, most often adhering to the dictates of the hanafì tradition, and in other

ottenuto dal beglierbei d'Aleppo che contra franchi fussero essaminati testimoni musulmani però in differenze che abbino con mercanti che non siano del paese. Egli propostosi [...] di tenerlo fermo, mi disse il commandamento non vi viene alterato se non in quella parte de mercanti forestieri, onde non vi dovete dolere, per chè à questo modo sta bene, che altrimenti non potendo loro forestieri saper il vostro commandamento facilmente sariano ingannati." ASVe Senato, Dispacci degli ambasciatori e residenti, B. 1A, 406-8.

177 "Ho mandato le sue lettere per Soria già 6 giorni à quel illustrissimo consolo con quel più di information che havevo circa l'arz per la revocation del commandamento novo, che intervenendo mercanti forestieri siano admessi testimoni mussulmani contra franchi et spero. ..." Following this are two lines in cipher, a sign of the importance given to the issue by Barbarigo, ASVe, Senato, Dispacci degli ambasciatori e residenti, Costantinopoli, B. 1A, 42 ov, 6 July 1557 .

178 ASVe, Senato, Dispacci degli ambasciatori e residenti, Costantinopoli, B. 1A, 422. 
cases vouching for their own interpretations, for example when choosing to consider mustǟmins and dhimmīs to be a single people. It is fair to see the ban on Muslim witnesses, at least, as being at odds with sharı̄a. Apart from the fact that, as a corrective measure the Aleppo ferman contravened a superior norm, it also represented a further step in Ottoman intervention in sharīa matters, such as the regime of proof. Furthermore, by issuing the ferman, the Ottoman sultan was implicitly admitting that the Ottoman-sponsored legal order might well have looked arbitrary to Muslims from outside the Empire.

\subsection{A Death in Damascus}

This chapter closes with the analysis of a highly disputed legal issue; the bankruptcy, arrest and subsequent death of a Venetian merchant in Syria, as well as a series of trials ensuing his death, seen through the lens of an exceptional trove of documents. The issue was debated in several legal forums, both in the Ottoman Empire and in Venice. Marco Priuli's bankruptcy was first brought before a qadi in Damascus in 1531, who, as we shall see, handled the affair under a narrow interpretation of Islamic law. A year later, the case was brought, in appeal, before the Imperial Dīvān in Constantinople. Besides its administrative and diplomatic capacities examined so far, the Dìvān also functioned as the supreme court, which included the hearing of mixed cases. The venetian bailos indulged in long descriptions of the Dìvān's procedure, noting the handling both of affairs of state and of lawsuits. ${ }^{179}$ To be sure, royal justice aimed to promote the rule of law, or shari $a$, as did ordinary judges; however, for the Priuli case traditional procedure and the witness system were handled with particular tact by the pashas.

Several years after the Priuli case was brought before the Divvān, a third, final trial was started in Venice by Marco's father, who accused his brother-in-law, Domenico da Molin, of stealing some of the gems left by Marco and of obstructing the investigation. What we know about the bankruptcy, escape and death of Marco Priuli emerges from this last trial, filed before the Venetian Giudici di Petizion. Unlike most trials heard by that court, for which only the final verdicts have survived in Venice's state archives, the Priuli vs. Da Molin case has left behind a hefty corpus of documents. This collection appears to

179 "Si riducono la mattina per tempo ed avanti il levar del sole, e vengono in divano; dove giunti, subito seduti li bascià, si appresentano in mano di Rusten tutti li artz, cioè querele, suppliche ed ogni altra sorte di scritture appartenenti cosi a materie e cause private come a cose di stato," Relazioni degli ambasciatori veneti al Senato, Serie III, Volume III, 154. 
be the file that was used by the plaintiff's attorney, including correspondence between the Priuli family and Marco's associates, the merchant's testament in Damascus, and other judicial documents, such as lists of Muslim and Jewish creditors. It also includes the final sentence given by the court. Marco's father sued Domenico da Molin, Marco's uncle and associate, who resided at the time in the Syrian coastal town of Tripoli, before this Venetian magistracy. According to Domenico, Marco was ready to buy anything, provided it was done by installments, and would even pay ten times its value, and the way he conducted his business in Syria raised murmurings of disapproval. Moreover, Marco cooked his books, cheated his associates, and made little effort to retrieve the credits owed to him. Marco's incompetence and malpractice as a merchant seems to leave little room for doubt, particularly since similar accusations can be found in the letters addressed to him by his own father. ${ }^{180}$

The Giudici managed to ascertain some facts regarding the events leading up to Marco Priuli's death. Having accumulated unbearable debts, he had fled Damascus for Tripoli, where he hoped to embark on a Frankish vessel. His uncle, Domenico da Molin, was a merchant involved in organizing the Venetian convoys that regularly arrived in Tripoli's harbor. Marco's creditors, in the meantime, had filed a complaint before the Ottoman pasha of Damascus. The Ottoman authorities dispatched two messengers (chiausi, Tr. çavuş) to Tripoli, found the uncle in his home, and brought him before the judicial superintendent, the emin. Domenico was forced to stand surety for his nephew, in accordance with Muslim custom. ${ }^{181}$ When Domenico returned home, he found Marco waiting for him. Fearing his imminent arrest, Marco handed a kerchief containing jewels to his uncle, some of which had been bought in partnership with him. Meanwhile, one of Marco's assistants was tracked down in Tripoli by the authorities, who proceeded to arrest Marco. After a period of detention in Tripoli, Marco was brought to Damascus and imprisoned in the Citadel, the medieval fortified precinct that still hosted the provincial government. Having fallen ill, Marco had his last will notarized in jail on the 5 th of October 1530 by the last known Venetian notary in Syria, Iacopo Vigulo. The document illustrates the context of legal hybridity that these merchants operated in; the deed records debts with Jews and Muslims drafted in Islamic contracts, as well as through acknowledgements of debt Marco himself drew up. Priuli admitted debts amounting to more than 5000 ashrafì, and left instructions to have his papers and an inventory of his jewels seized by the notary.

180 BC, Manoscritti Provenienza Diversa c. $508 \mathrm{c} / 2$, 3or.

181 BC, Manoscritti Provenienza Diversa c. 508c/3, 2 "dar alle fin piezaria del viso come de lí se usa." 
When Marco passed away in the Citadel's dungeons, the judicial authorities had his body searched, and found two compromising letters he had received from his uncle Domenico while in detainment. In the letters, Domenico overtly mentioned the jewels he had received from Marco in Tripoli. These letters were handed to the qadi, who proceeded to notarize them. The discovery of this correspondence seriously complicated Domenico's position, who was finally arrested in Tripoli. However, he managed to delay his transfer to Damascus, as he was busy with the galley season in Tripoli. When he was eventually conducted to the provincial capital, Domenico took the stones, and put into a sealed bag those bought in partnership with his deceased nephew, and which he had tried to save from confiscation on the basis he had a share on them. Domenico also took a "big, long Indian diamond" and a ruby worth 5000 ashrafi— - the gems that had precipitated Marco's bankruptcy—and hid them in his clothes. Eventually brought before the pasha of Damascus, who was clearly conducting an investigation, Domenico was questioned about his involvement in his nephew's bankruptcy. According to his first version, Domenico and Marco had purchased some stones together-those he was carrying in the sealed bag - while he denied any share in other purchases made by his nephew. Domenico showed the pasha the jewels both relatives had bought as partners, but the letters were read publicly in his presence, whereupon he admitted having kept the large Indian diamond and the ruby. Though Domenico confessed to the judiciary commission that he had kept the stones, one cannot blame the pasha for not believing Domenico's explanations. Domenico told the pasha that during his journey to Damascus, the two gems fell from his clothes and were lost. As a result, the stones in the sealed bag were confiscated, and Domenico ended up in jail. Domenico's story, as it was reconstructed later by the Venetian judges, presents us with a number of surprises. During his imprisonment, a Muslim woman had found the stones in the streets of Tripoli, and had sold them to two Jewish jewelers, the Cohen brothers. The confused judicial narrative is difficult to reconstruct, but the implausible story of the discovery became known to the authorities, inducing the local governor, the Sanjakbey Süleyman, to confiscate the stones as well as any property he could connect to Marco. To further complicate the story, the governor was subsequently transferred to the Sanjak of Maraş and carried the stones with him.

Another murky chapter in the Priuli affair concerns Marco's account books, which were dispersed. Some of them were sequestered by judicial officers, others ended up in the hands of partners, heirs, and the Cohen brothers. ${ }^{182}$

182 BC, Manoscritti Provenienza Diversa c. 5o8c/2, 17-18. 
Andrea Priuli, a relative dispatched to Syria to square off what was left of Marco's business, managed to obtain a compromising book. It contained evidence of Marco's purchases of pearls and diamonds, and Andrea was scared the creditors would seize it. The Priuli, while accusing Domenico of smuggling Marco's records, were themselves hiding evidence from Ottoman judges. Domenico knew that his nephew's accounts would not be of much legal help. He was a veteran in the trading milieu of Aleppo and was the object of a similar lawsuit in $1540 .{ }^{183} \mathrm{He}$ recovered the records in the hands of the Cohens and sent them to Marco's brother, Zuan Francesco, in Istanbul. "I do not know what evil frenzy has brought you and your father to accuse me of having hidden these papers," reads the letter accompanying the package. ${ }^{184}$ By the end of Marco's financial downfall, Domenico says, his accounts had already been falsified, and some partnerships poisoned with inflated, fake purchases of jewels. Money owed to Muslims had not been properly annotated, and the credits granted by Marco were not always registered by a qadi's hujja, which made them impossible to recover.

Overall, however, Marco Priuli's accounts records were of meager evidentiary value for the Ottoman judges. After his death, both Frankish and Ottoman subjects rushed to the qadi to have their debts registered. Andrea himself tried to certify one of Marco's credits left in Aleppo, but found no Muslim still able to bear witness to that transaction. ${ }^{185}$ The sultan intervened by sending orders to a qadi of Damascus to have some old credits certified, such as one owed by Marco to a certain Abū Jum'a al-Maghrebì. Some credits, such as the money owed by the Syrian chief Qadi Ibn Farfür and his daughter Fāṭima, had been sold to third parties. This "cadi grande Sidi Farfor" was most probably Walī alDīn Ibn Farfür discussed in Chapter Two, who remained in charge until 1530 and whose family is often mentioned as being involved in cases of embezzlement. Moreover, some of Priuli's debtors were dead, a legal problem to which I will return. It may seem that in the early 1530s, the Venetians were not particularly familiar with the certifying procedure, and indeed the consul monitored his subjects' agreements to ensure that they were registered at the courthouse. As Andrea was painfully coming to realize, local Muslims and Jews had taken

183 ASVe Correr di Santa Fosca, 11 / 162, 11 May 1540.

184 BC, Manoscritti Provenienza Diversa c. 508c/3, letter dated 15 April 1531, "le qual scritture non so da qual diabolica frenesia tentato tuo padre, et voi tutti voletti, che io avessi occultato".

185 BC, Manoscritti Provenienza Diversa c. 508c/6, 2v, "niuno s'atrova in Aleppo apresente non so si debbo farla meter de qui e per non aver niuno possa testimoniar di saper salvo Musulmani." 
great care to register their debts, which was not the case for the majority of Marco's credits.

The Priulis also came up against the Ottoman custom of privileging the claims of living creditors over those of dead people. "Proof is not accepted against the affairs of the dead," Bailo Antonio Rizzo pointed out in 1556.186 Rather, it seems it was almost impossible to obtain satisfaction, in practice, for quantities exceeding 30,000 aspre. Large sums owed to dead creditors were often used to repay the smaller debts of the living. The Venetians were puzzled by the sharīa approach to this issue, as they were instead used to dealing legally with their deceased ancestors, whose last wills were taken care of by the Procuratori di San Marco and other testamentary executors. The legal practice of administering inheritances, or commissarie, was deeply rooted in Venetian society. One could sue the dead, who in exchange could collect rents and pay pensions for generations or even centuries after their passing.

\subsubsection{The Priuli Case in Court}

The Priuli affair was first heard by the qadi of Damascus as early as 1531. The judge was unwilling to accept any claim not supported by proper certification. An additional complication emerged: although the Priuli managed to retrieve some of their credit claims with certified documents, the qadi considered this evidence to have been produced by Christians, and, although acceptable, priority was to be given to the satisfaction of Muslims. Fatwā collections and hanafì jurisprudence on common practice at the time sponsored this solution for cross-confessional debts. ${ }^{187}$ The qadi, therefore, stipulated a "very strict clause" by virtue of which credits held by Muslims had to be repaid first, arguing that otherwise, as Bailo Pietro Zen explained it, "proof produced by us Christians ... could be used against the interests of Muslims." 188 Thirdly, and more intriguingly, the lawsuit echoes the peculiar application of the witness system that was being adopted by the early Ottomans. As the Priuli repeatedly argued, their defense was hampered by a ban on the recourse to Muslim witnesses,

186 ASVe Senato, Dispacci Ambasciatori e Residenti, Constantinopoli 1A, 304, 11 July 1556, "che non si admetteano prove contra le cose de morti”. BC, Manoscritti Provenienza Diversa c. $508 \mathrm{c} / 6,2$, "l'è consueto fra loro che quando quando una persona mora, cui diebba haver piui di saraphi 1500, che sono aspri 30.000 , besogna vadino in iustification [...] coloro che die haver meno de la tal suma che iustificano de qui malmente sono pagati."

187 Grignaschi: "témoignage des sujets non musulmans", 221.

188 BC, Manoscritti Provenienza Diversa c. 508c/1, 15r-v, "che lui chadi vedendo le pruove mie herano di nostri cristiani volse meter una clausula aspera dura e severa che il credito nostro non fusse satisfato salvo da poi satisfar i mori dicendo [15v] che le testificatione de cristiani sariano a preiudicio de mori." 
"whose testimony it has been forbidden for us to have."189 It is possible that this specific ban was due to a cultural misunderstanding, as in mixed cases for nonMuslim plaintiffs the ideal solution was always to seek the support of Muslim witnesses. In any case, the ban on cross-confessional witnessing, as we shall see, was again invoked when the trial was later heard by the Dìvān.

Incidentally, a process heard by the Bailo's consular court in 1545 accounts for this climate prone to cultural misunderstandings and, maybe, for opportunistic uses of religious differences on issues of proof. The defendant, Antonio Calvocoressi invoked a number of legal arguments, supported by his own cross-confessional interpretations, in order to discredit a hostile witness, a courtier named Giacomo Leoncino. Calvocoressi claimed that Leoncino was charged with murder and banished from Venice, where he was legally married, while in Istanbul he had concubines "at the Turkish manner". Calvocoressi brandished quotations from the Old and New testaments against Leoncino's ability to give testimony. Courtiers do not qualify as witnesses, he argued, since they tend naturally to benefit their clients' interests and to "utter a thousand lies". Moreover, courtiers' testimony had been invalidated in some trials in Venice and this was the usual approach by sharîa. Whence such a nonsense comes from, the judges replied, we do not know, if it is not actually from the Law of the Turks. To be sure, Calvocoressi's claims were thrown out by the court, although it is significant that even experienced Levantine traders-Calvocoressi was a well-known family from Chios- attempted, on occasion, to play the card of religion when trying to discard witnesses. ${ }^{190}$

As Marco's relatives viewed things, sharīa procedure constituted a serious obstacle to their interests, and the Priuli believed their evidence would be handled differently at the Dīvān-ı Hümāyūn. In order to have their case transferred to the Divān, the approval of the local governor was required, who may have collected a large sum for the transfer. In addition, the bailo's "favor and support"

189 "accio non li fusse fato un simel torto, che torto possiamo dirlo, quando per mancamento di testificatione di mori non vi fusse dato il nostro, le qualle testificatione a noi sono prohibite di poter haver.", BC, Manoscritti Provenienza Diversa c. 508c/1,15v.

190 "Quarta oppostione se le opponne che non é creduto in juditio per far la sansaria si come ne havenno casi seguidi in venetia et manco inquesta terra alla rason turchesca non vengono tolti per buoni testimonij percio che quella sua arte si é fundata quali sensari non ponno far di manco cha non dicano mille busie ni contrattar li mercadi et per far piacer à uno amico" [...] Alla terz oppositione se gli risponde che se ben è compare del predicto messer Piero questo per legge non è possibile, nè manco in osservantia è et si simil corrutella si observasse, seria causa che pochi seriano compari [...] alla quinta opposition oppone per esser sanser non deve esser creduto in Juditio, questa è vana; et non merita risposta alguna non sò dove il Reo se imagina componer di sua immagination tal ambagis, non é manifesto che uno sansaro é creduto nelli soi mercati solum dove bisogna doi testimonij et il sansaro solo é creduto, non so in qual legge lui trova, se non fosse come lui dice alla turchesca", ASVe, Bailo a Costantinopoli, 263, 39r-43r, 17 July 1545. 
were required, not because of any consular prerogative, but because of his role as a community representative. This intercessory role raises the question of whether consuls were merely representatives, or were actually held accountable for their subjects' actions. Normative sources such as the ahdnames insist on individual responsibility, but according to Bailo Antonio Rizzo, in 1555 the situation was far more complex. Trials before a local qadi were considered to be "private," but they became "public" when brought for appeal before the Dìvān. In these cases, Rizzo continues, the bailo could be considered responsible for the economic losses incurred by the Venetian subjects under his protection. This seems to have been just as much the case for Venetians who were longterm residents or married to Ottoman subjects, and who had ended up fleeing the Empire to escape debt. ${ }^{191}$ In other words, Venetians made a permanent choice when they became dhimmiss, and should avoid the temptation to leave the realm of Islam, since otherwise damages could be pinned on the bailo.

Contrary to what appears to have been common practice with Ottoman petitioners, whose cases were for the most part based on paperwork, there were hearings. ${ }^{192}$ The parties were expected to show up in court, although as we saw earlier experienced defendants such as Abdellatif could use delay tactics and calculated absences to defer the trial. Sometimes they decided not to bring their witnesses, or show up just before the end of the session, hence avoiding formal questioning. Sometimes the bailo attended sessions personally, while at other times he simply sent his secretary, depending on his interest in speeding up the matter. Although the traditional approach to evidence was never questioned at the Divvān, in practice the Priulis' expectation that proof would be handled differently was confirmed. However, even though the Venetians had their own witnesses, Bailo Pietro Zen adopted the strategy of presenting the case as something to be handled by the representatives of the two communities. Zen's witnesses had even been prepared, but insofar as was possible he hoped to avoid their being put upon the witness stand, and he saw the recourse to witnesses as a potential dishonor. ${ }^{193}$ This echoes the Syrian consul's choice to allegedly refuse to

191 "questo difficillmente si potrebbe fare, sarebbe voler far publice le cause private, et consequentemente pigliare li debiti nella serenita vostra perche il capitolo dice, che se alcuno averà difficoltà col bailo, la causa sia giudicata alla Porta et questo si intende nelle cause publice solamente perchè uno altro capitolo dice che le cause de privati siano giudicate dal caddi,", ASVe Senato, Dispacci Ambasciatori e Residenti, Constantinopoli 1A, 184-5, 29 October 1555, 204V, 30 November 1555 .

192 Baldwin, James E., "Petitioning the Sultan in Ottoman Egypt", Bulletin of the School of Oriental and African Studies 75 ०3 (October 2012), 499-524.

193 BC, Manoscritti Provenienza Diversa c. 508c/4, 47 et ss, "el magnifico imbasator vuol veder ad ogno modo di far di mancho delli testimoni per esser cosa pericolosa di perder poi dillo honor." 
produce witnesses against Abdellatif, on the grounds that such a measure would undermine the privileges granted in the treaties banning Muslim witnesses. ${ }^{194}$

As a sign that mixed cases were treated by the Divañn as a communal matter, rather than issuing from individual petitions, in the Priuli case the bailo's priority soon shifted from defending the Priulis' interests to those of other Venetian associates, such as Girolamo Venier. As the documents report in rather graphic language, if Priuli had already been "put away," some of his partners still had a chance to recover their money. Indeed, Venier was able to prove through registered contracts that he had purchased jewels in partnership with Marco, and was therefore entitled to save his share from confiscation. Zen's strategy was, to everyone's surprise, that of accepting the validity of all Muslim claims against Marco Priuli. ${ }^{195}$ In exchange, Zen demanded satisfaction for Venier, whose jewels had been seized and who risked losing everything. This put the pasha in an uncomfortable position; if he accepted Zen's requests on Venier's behalf, giving satisfaction to Christian debtors would thwart the compensation claims of other Muslim debtors (Venier's stones were worth no less than ten thousand ducats). The pasha was displeased with this complication, since the plaintiffs insisted that Venier's claims needed to be confirmed by Muslim witnesses. Yet surprisingly, Venier had produced these Muslim witnesses, and they were ready to testify. This was precisely the kind of situation the qadi of Damascus had labored to avoid. On the other hand, it is clear that the Divañn could not afford to dismiss every single one of the bailo's claims on the grounds of the witness system. This uncomfortable legal situation materialized during the hearing; both parties had witnesses waiting outside the room, ready to be called to testify. Nonetheless, hearing the witnesses implied permitting an unbeliever to make use of Muslim-produced proof to his own interests. This could threaten the specific Ottoman approach to the witness system, in the same manner that it had earlier in the sharīa court. Accordingly, the Ottoman plaintiffs insisted on having their witnesses heard and objected to the Franks that "you cannot have a Moorish witness." 196 Eventually, the Pasha judged it to be more judicious to simply leave the witnesses waiting at the door.

If, for Zen, there was no honor in seeking the testimony of witnesses, the pasha was left with a similar dilemma: either he could validate facts by

194 ASVe Senato, Dispacci Ambasciatori e Residenti, Constantinopoli 1A, 228v, 8 February 1555.

195 "el magnifico imbasator comparse alla porta dove disse haver visto tutte le rason de mori et haver in nota su una poliza li crediti loro secondo vi dico di sopra, et confesso el tal die haver et tal tanti, dove el Bassa vete sta realta che sua [61r] magnificentia trova tutti loro crediti giusti et senza contrastar dove si meraviglio et li piacque molto." BC, Manoscritti Provenienza Diversa c. 508c/4, 6ov.

196 BC, Manoscritti Provenienza Diversa c. 508c/4, 6ov, "et con molte gran parole dicendo poi di mori voleva contrastar su queste dicendo tu non poi haver testimonianza morescha.” 
summoning witnesses for Christian plaintiffs, or he could simply trust the bailo's word, held in particular consideration at the Dīvān. This, again, constituted an anomaly in court practice, although there existed precedents in which the bailo's word had been invoked to certify facts in mixed cases, and even used to release a prisoner. In 1557 Antonio Rizzo asked the doge whether, prior to the last treaty that had been concluded, it was customary to accept the bailo's word on the release of captives. Rizzo mentions several occurrences in which he had prisoners freed on his word alone. ${ }^{197}$ Similarly, Zuan Dario reports a long conversation about the release of captives, in which the pasha admitted that accepting Christian testimony was out of the question, but reminded the bailo that captives were sometimes set free on his word. ${ }^{198}$ Rizzo's successor Antonio Barbarigo had to deal with an episode that had happened twelve years before his tenure, and that the pasha was now laboring to reopen, concerning a Venetian subject, Agostino, accused of having seized the ship of Hacı Kamali, bound for Ancona. The bailo argued that Agostino was not guilty, and that if he had been released then a qadi's hujja ("sigilletto del cadi") should exist, attesting to his innocence. The pasha admitted that the issue had been tried at the Dìvān "where they do not make notes," and that Agostino had been found guilty of all charges. When the bailo argued that Agostino must have been released pursuant to an agreement between the parties, the pasha retorted that he had been released on the bailo's word alone, and that now the plaintiffs had become more powerful and were demanding satisfaction. ${ }^{199}$ Barbarigo goes on by invoking a number of arguments, such as the existence of a statute of limitations, the fact that the former bailo Stefano Tiepolo had passed away, and that secretary Giannesino had now forgotten the relevant facts. Be that as it may, the Dìvān stuck to sharī'a forms of procedure, but also hosted notions and practices that reminded the legal autonomy granted to dhimmì communities. Although we have descriptions of the Dīvān's paperwork and the drafting of final hujjas, proper proceedings were not kept, and the role of the archive was played by memory and orality. Yet the important function of oral agreements

197 "la qual cosa, per quello che sono informato, si osservava altramente avanti li presenti capitoli, perché era creduto alla parola di Vostra Serenità, ovvero delli rappresentanti suoi; e se ben è successo a me alcuna fiata il medesimo, che sopra la mia parola ne ho avuto alle flate dal magnifico lbraim bassà, al tempo che il Signor era in Persia, e che la Magnificenza Sua era governatore in Costantinopoli, avendoli io detto oh' ella mi credea in molto maggior cose; e ne ho avuto da poi il ritorno del Signor in Costantinopoli con il mezzo del magnifico capitano, il quale mi ha fatto fede al magnifico hassà, ch' erano sudditi di Vostra Serenità", Relazioni degli ambasciatori veneti al Senato, Serie III, Volume III, 143.

198 Dario, 22 dispacci, 92-4.

199 "et lo dimanda à mé, come quello che lo ha rilassato sopra la parola del bailo", ASVe Senato, Dispacci Ambasciatori e Residenti, Constantinopoli 1A, 432r. 
did not necessarily play out to the advantage of Muslims alone, as in the case of Agostino's release. In any case, it is clear that, as the head of his community the bailo's word was invested with a particular charisma, and that it contributed to breaching the wall erected by the biases. ${ }^{200}$ Accordingly, and to return to the Priuli lawsuit, the pasha then made a highly significant statement: "Bailo, do as it pleases you, I believe you more than I do forty Turks." In other words, regarding the hearing of witnesses, the pasha did not intend to adhere strictly to sharīa procedure. ${ }^{201}$ In the end, no witnesses were heard, Zen saved his honor and his word was trusted, and Venier recovered his stones, at the expense of other credits owed to Muslims. Everyone was stupefied, Priuli stated, adding that he could not believe it himself.

To be sure, the Burletto, Abdellatif or Priuli affairs are evocative of the complexity of the Veneto-Ottoman "special relationship." Protracted over many Dìvān sessions, the sophisticated debates and concessions from both parties make it clear that this relationship was of a political nature. While this relation is increasingly being addressed by researchers from history of communication, diplomacy or espionage perspectives, my use of these stories and in general, of the very talkative and colored Venetian sources intends rather to illustrate the fact that these door-to-door neighbors were legally different, and became gradually aware of their differences throughout the 16th century. In contrast with the medieval merchant, who seldom concerned himself with the technicalities of the Islamic legal system, I believe that much of the perceived difference between Muslims and Europeans in the early modern era stemmed from the divergent nature of their legal systems, which impacted the conduct of trade, litigation and or the practice of diplomacy. However, this impact has gone mostly unnoticed, probably because specialists in Islamic law and institutions are not concerned with the agenda of world, trans-imperial history and with cross-confessional relations. Similarly, it seems to me, historians of the Ottoman empire are too busy looking for facts and explanations, as for instance when scrutinizing the letter of the ahdnames, and often miss the more important moral meanings people connected to these rules and practices. Studies

200 "mi rispose non vi só dir altro bisogna che si adimandi di là al bailo di quel tempo, et a Zanesino di qui, che saperà informarvi, per il che le dissi che il clarissimo bailo di quel tempo che era il clarissimo messer Stefano Thiepolo [...] era passato a miglior vita, et Zanesino anco non se lo ricordava essendo andati tanti anni da poi", ASVe Senato, Dispacci Ambasciatori e Residenti, Constantinopoli 1A, 432r.

201 "Adunque questo pover'homo de Hieronimo saria ssassinato che sapendo lui Marco dovesse morir, et desputo cosi certe parole su sta cosa, et voleva [6iv] far intrar li mori dentro, et pregava el bassa li lassasseno intrar anchor loro, accio dicesseno le sue rason, dove il bassa non volse mai lassarli vegnir et dise a l'ambasator io te credo piui a te che a 40 turchi, fa quel che ti piace, et ordino fosse tolte le buste di mani de el emin de morti." BC, Manoscritti Provenienza Diversa c. 508c/4, 6ov-6ir. 
on dhimmīs abound, yet surprisingly, if we take into account the social landscape of early modern Mediterranean port-cities, there is little written about legal relations and the mustāmmins. In the Dīvān arena for cross-confessional relations, the divine character of the law made issues stemming from religion much more sensitive, as epitomized in the role of witnesses, and accordingly bailos and ambassadors learned to handle these issues with tact. We have seen them coping with technical aspects related to proof and evidence, estate law, or the intricacies of the dhimmī status. Sometimes, a divide opened between actual practice and the letter of the treaties, as was the case for contradictions in the principle of individual responsibility, when the Venetians realized that there was a doctrine on 'public' disputes, for which the whole community was liable. In 1556, Bailo Barbarigo was forced to intervene during a Dīvān hearing because he did not agree on a matter of translation into Turkish of the word 'truce,' demonstrating proof of his knowledge of amān theory. ${ }^{202}$

Whether they were deeply rooted in jurisprudence or not, the ban on crossconfessional witnessing and the dhimmis' attempts to forbid the use of Frankish witnesses underline the fact that a specific approach to proof was part and parcel of Ottoman governance. Snjezana Buzov has criticized the monolithic vision of historiography of harmony between actual governance and rule of law, according to which the jurists' priority was to provide legitimacy for the sultan's claims. ${ }^{203}$ Significantly, Ebu's-Su'ud himself raised objections against Ottoman policies on issues of testimony and unbelief, as in the case of the bailo Amer and his dhimmì witnesses. These peculiar notions and practices were accompanied by other legal ideas of a more anomalous nature. If the ban on Muslim witnesses meant twisting the arm of traditional sharīa procedure, arbitrary suspensions of it such as that decreed for Aleppo constituted an exception to the exception. The legal grounds upon which Ottomans claimed the existence of a universal dhimmimustämin nation are equally intriguing. Similar questions could be raised about the value given to the word of the bailo at the Divañn supreme court, and, above all, to the ambiguous ban preventing the Priulis' attorneys from availing themselves of Muslim testimony, a defense universally accepted in Muslim societies. Although it is difficult to know the extent to which these bans, anomalies and adjustments were enforced in practice, there seems to have existed a legal ethical code, based on unwritten rules and shared notions of justice, according to which the production of evidence was held up to a confessional framework.

Guy Burak, Snjezana Buzov and Reem Meshal have demonstrated that Ottoman legal reforms, which were moving towards a more universal and homogeneous law, and away from local custom, were instrumental in fashioning a new

202 ASVe, Senato, Dispacci degli ambasciatori e residenti, Costantinopoli, B. 1A, 377-384.

203 Buzov, The lawgiver and his lawmakers, 80-1. 
imperial sovereignty. ${ }^{204}$ It was in fields such as the laws of evidence and obligation that earlier legal customs were more systematically dismissed. To be sure, the Ottomans did not discuss sharía principles governing exchanges with unbelievers, but they did criticize "corrupt" judges' and professional witnesses' formalist attachment to rules and procedures. The unusual approach to minority witnessing, so confusing to Venetian litigants, was part of the Ottoman project to build a religious and legal orthodoxy that stood in contrast with the old Mamluk "orthopraxy."205 And indeed, the story of the two corrupt 'udūl in Cairo that opens this book epitomizes the formalistic approach that the Ottomans were contesting. The way in which the different affairs described in this chapter were handled demonstrates that these policies were not just an excuse for dismissing all Frankish claims related to diplomacy, ransoming and borderland relations on religious grounds. The strategies of plaintiffs to gain leverage by playing with conversion were not always successful, and indeed legal principles, such as the superiority of the Muslim word and the hanafi exception were not just government injunctions imposed from above, but equally invoked and manipulated by the plaintiffs.

We have seen that the sultans and their representatives invoked time and again before their Venetian counterparts the need to comply with the principles of sacred law. The biases against non-Muslim witnesses characteristic of shari`a, treated by the Mamluks as a legal technicality, had important meaning for the Ottomans. These principles served as a means for them to differentiate themselves as a political community, delimited by identity boundaries, and to mark out their vision of the Ottoman sultan as a champion of the rule of law. Perhaps for this reason, claims and bans such as these were heard at the Ottoman courts for at least fifty years, and crystalized around the ahdnames over the following centuries. To be sure, the biases against minority witnessing helped to demarcate social and religious boundaries, but they never constituted the unbreachable 'bronze wall' described by Western jurists. ${ }^{206}$ However firm Ottoman adherence was to the principle of Muslims' superiority as legal actors, the potential damages of discrimination were counterbalanced by a new and opener attitude towards written evidence, that did away with the archival divide between Medieval and Modern, East and West. In addition, not only educated diplomats, but all actors, ranging from pirates to merchants and captives, proved to be familiar with each other's legal practices and with some basic sharī‘a principles, making legal divides open to negotiation.

\footnotetext{
204 Ibid., 7.

205 Meshal, "Antagonistic Sharīas", 211.

206 Contuzzi, La istituzione dei consolati ed il diritto internazionale europeo nella sua applicabilità in Oriente, 145.
} 